\title{
CONSUMO TOTAL E RESIDENCIAL DE ÁGUA TRATADA: APLICAÇÃO DE UM MODELO DE SÉRIES \\ TEMPORAIS EM PIRACICABA, SP
}

\author{
ANA MARIA PEREIRA AMARAL \\ Engenheira Agrônoma
}

Orientador: Prof. Dr. RICARDO SHIROTA

Tese apresentada à Escola Superior de Agricultura "Luiz de Queiroz", Universidade de São Paulo, para obtenção do título de Doutor em Ciências. Área de Concentração: Economia Aplicada

PIRACICABA

Estado de São Paulo - Brasil

Agosto -2000 


\title{
Dados Internacionais de Catalogação na Publicação (CIP) DIVISÃo DE BIBLIOTECA E DOCUMENTAÇĀO - Campus "Luiz de Oueiroz"/USP
}

\author{
Amaral, Ana Maria Pereira \\ Consumo total e residencial de água tratada: aplicação de um modelo de séries \\ temporais em Piracicaba, SP / Ana Maria Pereira Amaral. - - Piracicaba, 2000. \\ $92 \mathrm{p}$. \\ Dissertação (doutarado) - - Escola Superior de Agricultura Luiz de Queiroz, 2000. \\ Bibliografia. \\ 1. Água potável 2. Aspecto socieconômico 3. Consumo hidrico 4. Tratamento 1. \\ Título
}

CDD 33.3 .91

Permitida a copia total ou parcial deste documento. deste que citada a fonte = 0 autor?

Data do depóslí junto CPG/ESALQ

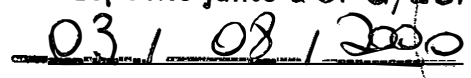




\section{DEDICO}

Aos meus pais Pedro e Virgínia, meu eterno agradecimento.

OFEREÇO

Ao Fernando 


\section{AGRADECIMENTOS}

Ao Prof. Dr. Ricardo Shirota pela valiosa orientação e amizade. Sem seu apoio, certamente não teria sido possivel a conclusão desse trabalho.

Ao Prof. Dr. Dalcio Caron pelas críticas e sugestões apresentadas e ao Prof. Dr. Evaristo Marzabal Neves por se dispor a participar deste processo.

Ao Pesquisador César Roberto Leite da Silva pelas críticas e sugestões apresentadas e disposição em participar da banca de qualificação e defesa.

À Maria Aparecida Maielli Travallini e à Helena Aparecida Cardoso, que em momentos diferentes, foram fundamentais para a conclusão dessa tese. $\grave{A}$ Cristiane Cipriano, pela ajuda oferecida.

Ao SEMAE Piracicaba, em especial à Adriana Maconatto, por fornecer os dados fundamentais para a realização desse trabalho.

Aos colegas de turma, em especial, Sueli, Mario, Rossana, Moretto, Leão e Márcia, pois juntos, superamos todos os obstáculos das disciplinas.

Ao Bruno Fontes que colaborou na obtenção de dados.

À Prof. Dra Zilda Mattos, ao tema e à ajuda no início deste trabalho.

A CAPES pelo apoio financeiro durante o Curso de Pós-Graduação. Aos professores do DEAS/ESALQ pelos ensinamentos recebidos.

Ao Instituto de Economia Agrícola por possibilitar a realização deste treinamento e a realização desta pesquisa Aos amigos da instituição pela paciência. Em especial, Marina Brasil Rocha e Silene Maria de Freitas pela revisão do texto. Ao Francisco A. Pino pela introdução nas séries temporais. À Rachel M. de Campos, à Irene F. Lucatto, à Vandete P. do N. Medeiros pela ajuda.

A todos que direta ou indiretamente contribuiram para a realização desse trabalho 


\section{SUMÁRIO}

Página

LISTA DE FIGURAS .................................................................... iv

LISTA DE TABELAS ........................................................................ vi

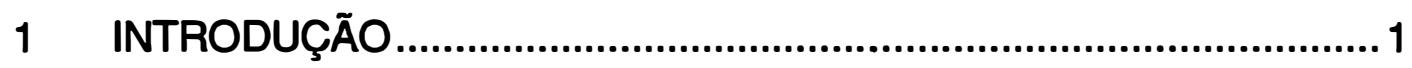

2 ÁGUA

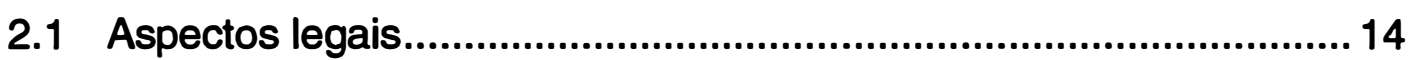

2.2 Os sistemas de abastecimento................................................... 18

2.3 Abastecimento em Piracicaba .....................................................20

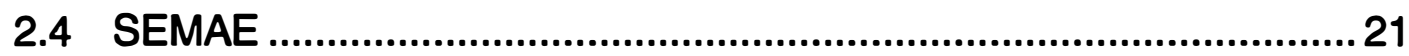

2.5 O sistema de abastecimento em Piracicaba..................................23

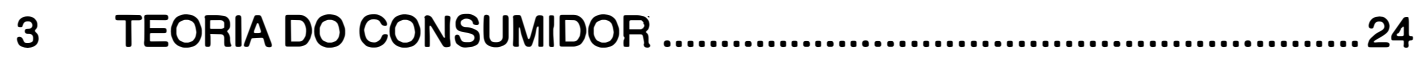

3.1 Preferência do consumidor: pressupostos.....................................25

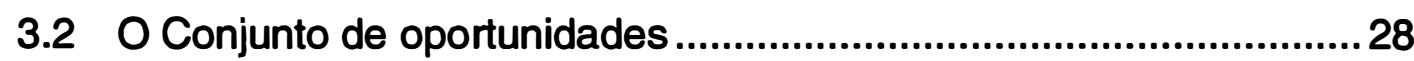

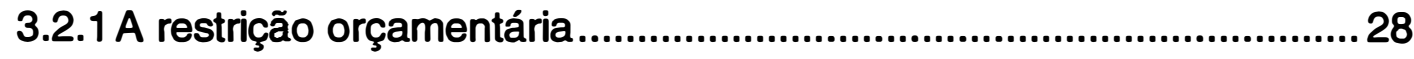

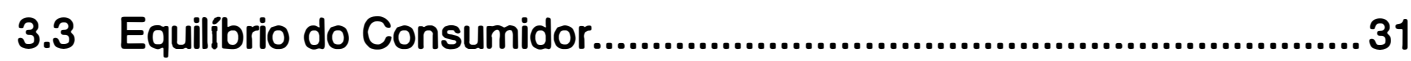

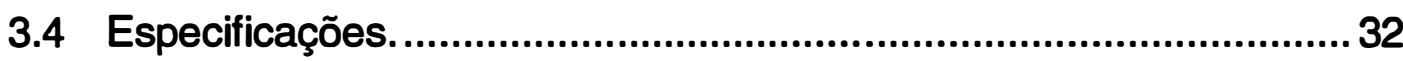

3.7 Problemas com Estrutura Tarifária em Blocos................................. 34 


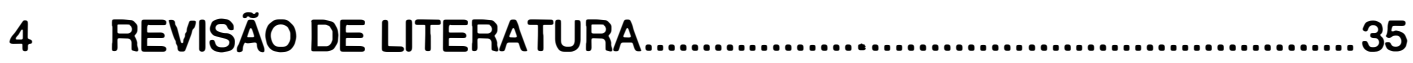

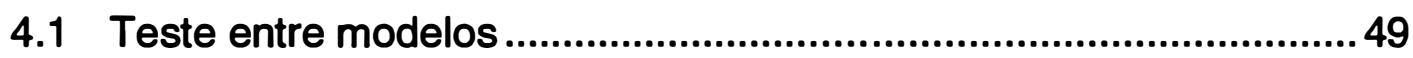

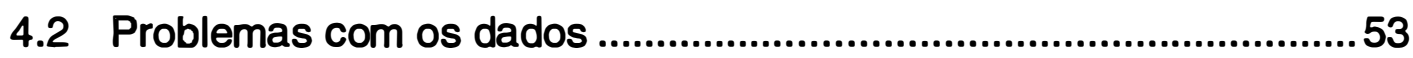

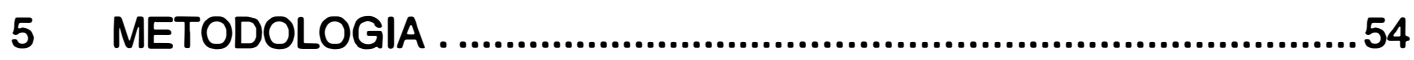

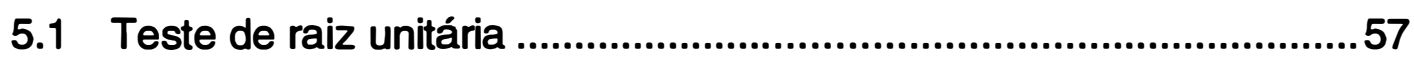

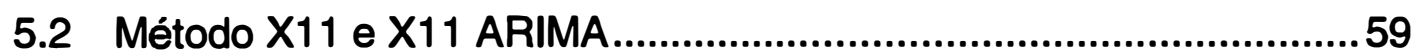

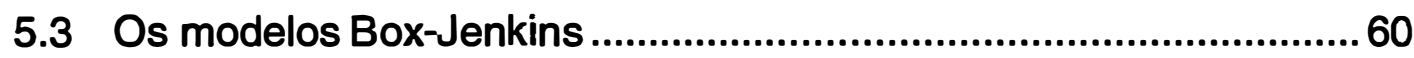

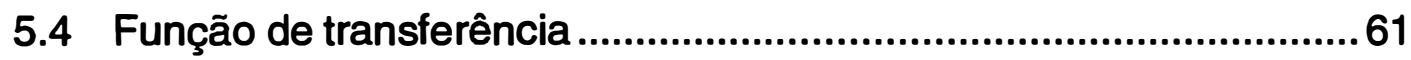

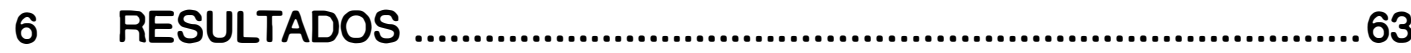

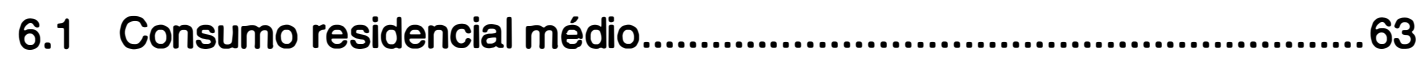

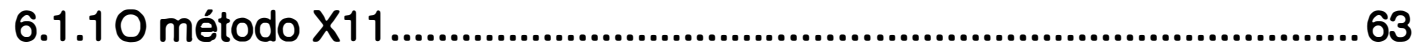

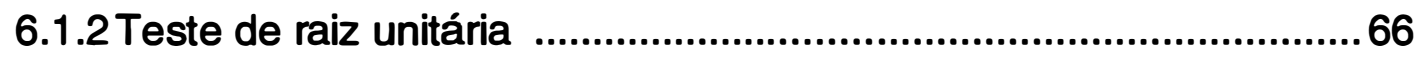

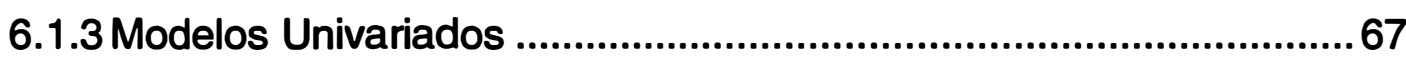

6.1.4 Função de Transferência ..............................................................68

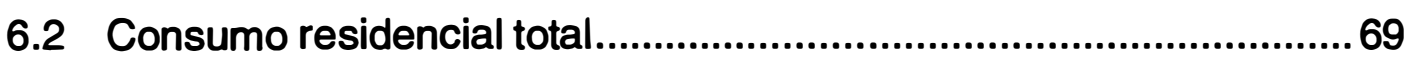

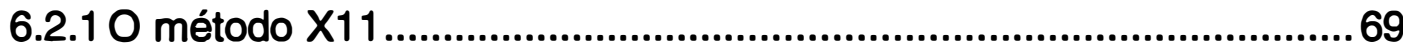

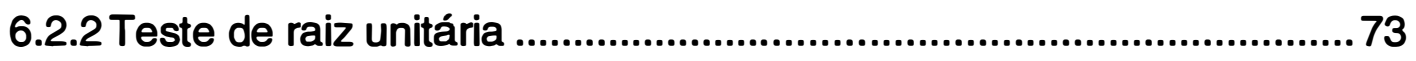

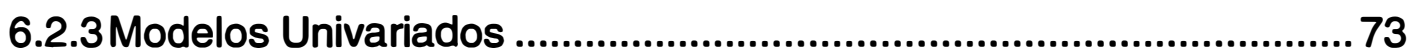

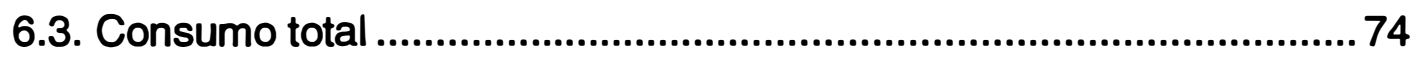




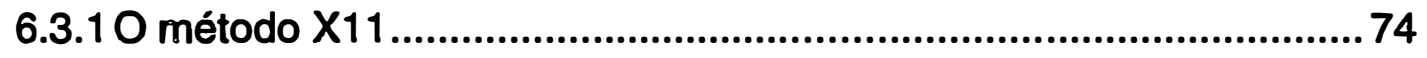

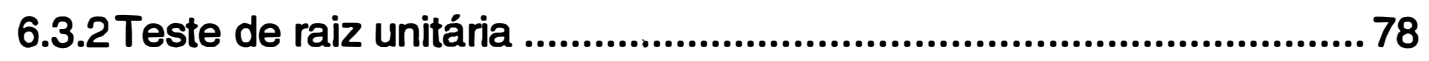

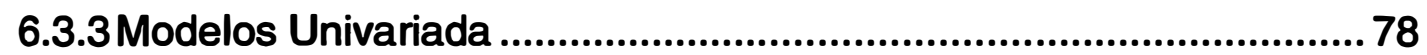

6.3.4Função de Transferência ............................................................. 80

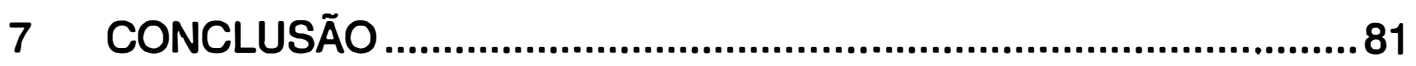

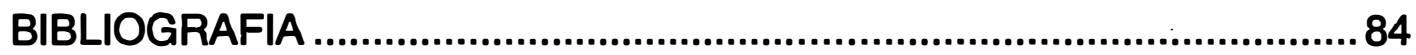




\section{LISTA DE FIGURAS}

Página

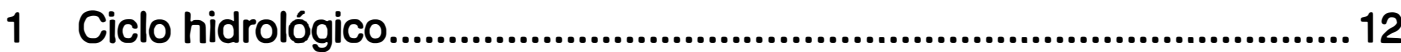

2 Mapa da Bacia dos Rios Piracicaba, Jundiaí e Corumbataí ...............20

3 Curva de demanda $D$ que relaciona preço $P$ e

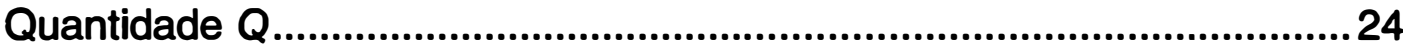

4 Restrição orçamentária do consumidor ............................................29

5 Restrição orçamentária com tarifas em dois blocos decrescentes

6 Valor da fatura de água, preço médio, preço marginal e diferença

7 Consumo Residencial de água, em $1000 / \mathrm{m}^{3}$ e Número de Ligações, Piracicaba, janeiro de 1993 a dezembro de 1999

8 Consumo de água total, comercial, industrial e outros, em $10^{6} \mathrm{~m}^{3}$ Piracicaba, janeiro de 1993 a dezembro de 1999 55

9 Consumo marginal média de água, em $\mathrm{m}^{3}$ /ligação e temperatura média mensal, em ${ }^{\circ} \mathrm{C}$, Piracicaba, janeiro de 1990 a dezembro 1999

10 Série Original e Sazonalmente Ajustada do Consumo Total de Água Tratada, Piracicaba, janeiro de 1993 à dezembro de 1999 
11 Série Original e Sazonalmente Ajustada do Consumo Residencial de Água Tratada, Piracicaba, janeiro de 1993 à dezembro de 1999 64

12 Série Original e Sazonalmente Ajustada do Consumo Residencial Médio de Água, Piracicaba, janeiro de 1993 à dezembro de 1999 65

13 Fatores Sazonais Mensais para a Série de Consumo de Água Residencial Médio para Piracicaba, Janeiro de 1993 a Dezembro de 1999 65

14 Fatores Sazonais do Consumo Residencial de Água, Piracicaba, Janeiro de 1993 à Dezembro de 1999 66

15 Fatores Sazonais Mensais para a Série de Consumo Total de Água para Piracicaba, Janeiro de 1993 a Dezembro de 1999

16 Série Irregular para a Série de Consumo Residencial de Água, Piracicaba, Janeiro de 1993 a Dezembro de 1999

17 Série Irregular para a Série de Consumo Residencial Médio de Água, Piracicaba, Janeiro de 1993 a Dezembro de 1999 .72

18 Série Irregular para a Série de Total de Água, Piracicaba, Janeiro de 1993 a Dezembro de 1999. .72 


\section{LISTA DE TABELAS}

Página

1. Oferta e consumo de água doce no mundo, por continente e Brasil 03

2. Distribuição de Água por Continente no Planeta. 11

4: Resultado dos testes de sazonalidade estável e móvel para consumo residencial médio, Piracicaba, janeiro de 1990 a dezembro de 1999.

5. Estimativas dos parâmetros dos modelos univariados e do modelo de função de transferência para o consumo médio residencial de água, Piracicaba, janeiro de 1990 a dezembro de 1999 68

6:Resultado dos testes de sazonalidade estável e móvel para consumo residencial médio, Piracicaba, janeiro de 1990 a dezembro de 1999 69

7. Estimativas dos parâmetros do modelo univariado e do modelo de função de transferência para o consumo residencial total, Piracicaba, janeiro de 1990 a dezembro de 1999.

8: Resultado dos testes de sazonalidade estável e móvel para consumo total mensal, Piracicaba, janeiro de 1990 a dezembro de 1999.

9. Estimativas dos parâmetros dos modelos univariados e do modelo de função de transferência para o consumo total médio residencial, Piracicaba, janeiro de 1990 a dezembro de 1999 


\title{
CONSUMO TOTAL E RESIDENCIAL DE ÁGUA TRATADA: APLICAÇÃO DE UM MODELO DE SÉRIES TEMPORAIS EM PIRACICABA, SP
}

\author{
Autora: ANA MARIA PEREIRA AMARAL \\ Orientador: Prof. RICARDO SHIROTA
}

\section{RESUMO}

O trabalho analisa os efeitos do componentes sazonais e de ciclotendência do consumo de água e estima a demanda de água total e residencial médio para a cidade de Piracicaba, estado de São Paulo, utilizando métodos de séries temporais e X11, para o período de 1990 a 1999. Dado a estrutura da cobrança da água ser em blocos crescentes, a maioria dos estudos sobre demanda de água discute qual preço que o consumidor reage, marginal ou médio e qual método econométrico deve ser usado para minimizar os efeitos da simultaneidade entre preço e quantidade consumida. Os modelos de séries temporais usam o passado da série para explicar o consumo atual. Nesses modelos, as variáveis preços (tanto médio quanto marginais), número de ligações, precipitação e proxy de renda não foram significativas. Os resultados

mostram que as três séries de consumo têm comportamento sazonal e que existe uma tendência de queda no consumo residencial médio e de aumento nos consumos total e residencial total nos últimos dez anos. Os modelos univariados mostram este comportamento sazonal, com parâmetros nas defasagens seis e doze. Nos modelos de função de transferência, a única variável significativa para explicar o consumo foi temperatura. Com base nos modelos e dados utilizados, o estudo conclui que o consumo de água em Piracicaba pode ser explicado principalmente pelo consumo passado da série e temperatura. 


\title{
TOTAL AND RESIDENTIAL CONSUMPTION OF TREATED WATER:
}

\section{A TIME SERIE MODEL APPLIED TO PIRACICABA, SP.}

\author{
Author: ANA MARIA PEREIRA AMARAL \\ Adviser: Prof. RICARDO SHIROTA
}

\section{ABSTRACT}

This study analyses the seasonal and cycle-trend effects of water consumption and estimates the total, residential and average residential water demand for the city of Piracicaba, state of São Paulo, using the method of time series and X11, for the period of $1990 \sim 1999$. Given the increasing block tariff, generally used for water pricing, most studies on water demand discuss whether the consumer reacts to the average price or marginal price and which econometric method should be used to minimize the effect of the simultaneity between price and quantity consumed. The time series models use past information to explain present consumption. In these models, the price variables (both average and marginals), the number of connections, rainfall, and the proxy for income were not significant. The results indicate that, in the last ten years: the three series of water consumption show seasonal behavior; the average residential water consumption is declining; and, the total consumption and total residential consumption are growing. The univariate models indicate such seasonal behavior with parameters in the lags of order six and twelve. In the transfer function models, the only significant variable explaining the water consumption was temperature. Based on the models and data used, this study concludes that the water consumption in Piracicaba, SP may be explained, primarily, with the past consumption and temperature. 


\section{INTRODUÇÃO}

O objetivo do presente trabalho é estimar uma função consumo de água residencial e total em Piracicaba, estado de São Paulo, analisando os efeitos de variáveis sócio-econômicas e climáticas na quantidade consumida. $\mathrm{O}$ conhecimento destes efeitos pode auxiliar no planejamento de abastecimento de água e contribuir com dados para a implementação da Lei 9.433, que prevê cobrança para todos os usos da água.

A necessidade de planejamento do uso da água decorre, fundamentalmente, do descompasso entre a crescente demanda requerida pela concentração populacional e a sua disponibilidade na natureza. A oferta de água é variável no tempo e no espaço. Podem ocorrer eventos críticos, tanto excesso como escassez, causando inundações, ou falta de água, que geram inúmeros efeitos sobre a agricultura, a saúde e etc. que se revertem em efeitos danosos à economia.

Além disso, existe uma série de razões que tomam o planejamento criterioso de seu uso de extrema importância. Entre outros podem ser citados: ela é essencial para a vida; sua quantidade é limitada; ela tem usos múltiplos; ela se movimenta no espaço; ela é relativamente renovável (Barbosa, 1997).

Do lado do consumo, é interessante observar que o consumo de água no mundo triplicou no período entre 1950 e 1999, tornando-se escassos em 23 países e atingindo mais de 230 milhões de habitantes. Em alguns países como Tunísia, Israel, Jordânia, Líbia, Malta e territórios palestinos a escassez atinge 
níveis abaixo de $500 \mathrm{~m}^{3} /$ hab/ano, enquanto a necessidade mínima é estimada em 2 mil m³/hab/ano' (França, 1998).

Nas regiões que apresentam precipitação inferior a $300 \mathrm{~mm} / \mathrm{ano}$, a vegetação é escassa e a produtividade de biomassa natural é inferior a 3 ton/ha/ano. Nas regiões de clima temperado, a precipitação atinge $550 \mathrm{~mm} / \mathrm{ano}$ e a produtividade ficar entre 10 a 12 ton/ha/ano. Na faixa equatorial úmida, a produtividade atinge 40 ton/ha/ano (Rebouças, 1999).

No mundo, $25 \%$ da população não tem acesso à água potável com qualidade aceitável e 66\% não possui saneamento básico, considerando o ano de 1996 (Hespanhol, 1999). No Brasil, o Censo Demográfico de 1991 mostrou que $86 \%$ da população têm senviço de água e $49 \%$ de esgoto.

* Estima-se que em 30 anos, a Terra deverá ter uma população de cerca de 8 bihões. Segundo previsões da Organização das Nações Unidas (ONU), nos próximos 25 anos, 2 bilhões e 800 milhões de pessoas viverão em regiões de seca crônica (Novaes, 1999). A Tabela 1 apresenta a oferta e o consumo de água no mundo, estando o Brasil em segundo lugar em disponibilidade de água per capita, abaixo somente da Oceania.

A política desenvolvimentista adotada no Brasil trouxe reflexos negativos nos recursos hídricos, sendo mais marcante nas grandes concentrações urbanas, onde concentram as necessidades hídricas da população, da industrialização ${ }^{2}$, de energia e de alimentos ${ }^{3}$. Os resultados tem sido a poluição de rios e lagoas, compactação e erosão dos solos que

${ }^{1} \mathrm{O}$ Banco Mundial considera como situação de estresse de água disponibilidade inferior a 2 mil $\mathrm{m}^{3} /$ hab/ano.

${ }^{2}$ Detritos industrias, resíduos de limpeza e produtos químicos da agricultura contribuem para a poluição dos recursos hídricos. Os gases dos automóveis e das chaminés das fábricas podem provocar chuva ácida.

${ }^{3}$ A necessidade de derrubada de matas para plantio ao longo dos rios e em suas nascentes provoca escassez de chuva e vem secando os cursos de água, sendo exemplo o Rio São Francisco que hoje tem menos da metade da vazão de 50 anos atrás (Teixeira, 2000). 
assoreiam os cursos d'água. Dessa forma, está ocorrendo a desorganização do ciclo natural de reposição das águas nos mananciais.

Tabela 1. Oferta e consumo de água doce no mundo, por continente e Brasil.

\begin{tabular}{|c|c|c|c|c|}
\hline \multicolumn{5}{|c|}{ OFERTA E CONSUMO DE ÁGUA NO MUNDO } \\
\hline & \multicolumn{2}{|c|}{ Oferta (deflúvio médio) } & \multicolumn{2}{|c|}{ Consumo $^{a}$} \\
\hline & $\begin{array}{c}\text { Total } \\
\mathrm{Km}^{3} / \text { ano }\end{array}$ & $\begin{array}{l}\text { Per capita } \\
\mathrm{M}^{3} / \text { hab./ano }\end{array}$ & $\begin{array}{c}\text { Total } \\
\mathrm{Km}^{3} \text { /ano }\end{array}$ & $\begin{array}{l}\text { Per capita } \\
\mathrm{m}^{3} / \text { hab./ano }^{-}\end{array}$ \\
\hline África & $3.996,00$ & $5.133,05$ & 145,14 & 2020 \\
\hline América do Norte & $5.308,60$ & $17.458,02$ & 512,43 & $1.798,00$ \\
\hline América Central & $1.056,67$ & $8.084,08$ & 96,01 & 916,00 \\
\hline América do & $10.080,91$ & $30.374,34$ & 106 & 335,00 \\
\hline Ásia & 13.2( & & 1.63 & 542,00 \\
\hline Europ & 6.23 & 7,45 & 455 & 625,00 \\
\hline Oces & $1.614,25$ & $54.7 \subseteq$ & & 591,00 \\
\hline Bras & $5.744,91$ & $34.784,33$ & 36,47 & 246,00 \\
\hline Mundo & $41.497,73$ & $6.998,12$ & $3.240,00$ & 645,00 \\
\hline
\end{tabular}

Fonte: WRL 1998 e Aneel 1999 (Am. Do Sul e Brasil). In: Galvão, 2000.

${ }^{a}$ Ano em que foi registrado o consumo: África: 1995; América do Norte: 91; América do Sul: 95; Brasil: 90; Ásia: 87; Europa: 95; Oceania: 95; Mundo 87.

${ }^{\mathrm{b}}$ Calculado com base na população no ano que foi registrado o consumo.

A escassez de água pode ser causada por fatores climáticos, mau uso ou agressão aos mananciais. No Brasil, todos os cursos de água que passam por centros urbanos estão contaminados em alguma intensidade (Krause, 1998).

A redução de perdas com a melhoria dos sistemas de distribuição, e a diminuição dos desperdícios pelos usuários pode resultar em uma economia considerável de água. Projetos financiados pelo Banco Mundial, em países em desenvolvimento, apontam que em média, $36 \%$ da água tratada é desperdiçada, enquanto em sistemas eficientes e bem administrados, as perdas variam entre 10 e 15\% (Salati et al., 1999). No Brasil existe uma diferença da ordem de $40 \%$ entre a água tratada e o valor faturado. Metade disso é perda 
física decorrente de má operação, tecnologia inadequada e má conservação na rede de distribuição. A outra é devido a perdas de caráter gerencial e administrativo ou fraude (Romano, 1998). No Rio de Janeiro, em 1990, a perda era estimada em $50 \%$. Porém, cerca de $80 \%$ do consumo era estimado e não medido por hidrômetro. Boa parte do consumo não contabilizado era devido ao consumo real ser maior que o estimado, pela falta de motivação em consertos e economia. A instalação de hidrômetros (numa área delimitada) reduziu o consumo após três meses, de 750 para 330 litros per capita.

Segundo o Banco Mundial, está cada vez mais difícil o aproveitamento de novas fontes de abastecimento, a partir de águas superficiais, para atender à demanda crescente. $O$ custo de construção cada vez maior, a oposição de ambientalistas e os limitados recursos disponíveis são razões apontadas para que o custo da água para fins domésticos em projetos futuros seja estimado em duas a três vezes maior que o de projetos atuais (Salati et al., 1999).

Está cada vez mais difícil encontrar água de qualidade, tanto para uso doméstico, como para irrigação. A escassez de água pode chegar a afetar 0 desenvolvimento de países emergentes e, pior, desencadear conflitos entre nações em regiões já instáveis politicamente como Oriente Médio e África 4 .

O Brasil é extremamente rico em recursos hídricos, possuindo entre $8 \%$ e $12 \%$ da água doce disponível no planeta. Porém esse recurso tem uma distribuição geográfica bastante irregular. Cerca de $80 \%$ desse potencial está localizado na Bacia Amazônica, onde residem apenas 5\% da população brasileira. Os restantes $20 \%$ da água está disponível em regiões onde residem 95\% da população. O Nordeste, em particular, apresenta historicamente os maiores problemas de carência hídrica. Tendo cerca de um terço da população brasileira essa região possui apenas 3,3\% da água disponível do Brasil.

\footnotetext{
${ }^{4}$ Egito e Etiópia brigam pelo rio Nilo; Síria, Iraque e Turquia pelo rio Eufrates; Jordânia e Israel pelo rio Jordão.
} 
Os problemas com abastecimento de água ocorrem em várias partes do Brasil. No Recife existe um sistema de racionamento de água que gera prejuízo para todos os setores da sociedade. Alguns bairros chegam a ficar 9 dias sem água no auge da crise. Na bacia do Rio Verde Grande, norte de Minas Gerais, existe conflito entre irrigantes de pequeno porte e irrigantes de pivô central devido à falta de planejamento. A água foi usada em excesso pela irrigação e está comprometendo o desenvolvimento industrial ao longo da bacia (Galvão, 2000).

O problema de água no Brasil não se deve à sua pouca quantidade, mas ao seu mau gerenciamento e à distribuição irregular da população pelo país. O estado do Ceará através do gerenciamento de barragens e adutoras está levando água para as cidades baixas. Dessa forma, Fortaleza não tem falta de água, apesar do rio mais próximo, o Jaguaribe, estar localizado a quase $100 \mathrm{~km}$ de distância. Entretanto, a cidade de Recife com o rio Capibaribe cortando a região metropolitana, sofre com constantes falta de água (Novaes, 1999).

A água é um recurso vulnerável, uma substância simples, capaz de diluir inúmeros produtos, inclusive de esgotos. Para tentar modificar 0 tratamento dado aos recursos hídricos no Brasil, o processo de gestão deixa de considerar a água como bem livre ${ }^{5}$. Sendo um bem escasso, o seu uso é passível de cobrança, que é justificada por dois aspectos: o primeiro é que a água tomou-se um recurso cada vez mais caro e escasso e o segundo é que a qualidade dos dejetos despejados no rio pode inviabilizar outros usos a jusante $\left(\right.$ Cordeiro $\left.{ }^{6}\right)$. Segundo a Constituição a água é um bem de domínio público, portanto a cobrança se justifica como receita patrimonial. Se a água é usada

\footnotetext{
${ }^{5}$ Bem livre é definido como aquele em que sua disponibilidade é ilimitada em relação a sua demanda.

${ }^{6}$ Citado por Novaes (1999).
} 
como insumo para gerar produção, renda ou lucro, os agentes econômicos podem pagar por seu uso.

A cobrança como um mecanismo de planejamento do uso da água encontra diversas dificuldades. A diversidade dos atributos como quantidade, qualidade, energia potencial e outros, caracteriza a água como um bem multiforme. Dessa forma, a sua oferta apresenta características particulares para cada manancial ou mesmo em trechos de um mesmo manancial.

Do lado da demanda, a água apresenta diversos usos, sendo difícil a sua valoração econômica. De acordo com a Lei 9.433 , a cobrança incidirá sobre o volume consumido (pelo princípio do "usuário pagador") e pelo volume e conteúdo dos efluentes que retomam aos mananciais (princípio do "poluidorpagador"). $O$ objetivo é que esse instrumento limite o uso perdulário e poluidor da água, promovendo o equilíbrio entre oferta e demanda.

O uso dos recursos naturais de forma ampliada pela capacidade humana de transformá-los e otimizá-los, no curto prazo, pode pôr em risco as possibilidades de crescimento futuro da sociedade. As premissas de desenvolvimento devem incorporar os limites de uso dos bens naturais, impostos pelas relações ecológicas e os valores de diversos segmentos sociais, sendo que o desenvolvimento deve ser contínuo, levando em consideração o uso futuro desse recurso.

A gestão do recurso hídrico visa, essencialmente, melhorar a qualidade da água de maneira a viabilizar seus múltiplos usos. Desde o "Código das Águas", de 1934, a legislação brasileira prioriza o abastecimento público. Apesar de antigo, o Código apresenta um exemplo da doutrina positivista do início do século, estando a maioria dos dispositivos perfeitamente atual. Porém, somente a parte do código das águas que trata do aproveitamento energético foi regulamentada. E o Código apresenta uma visão de gestão dos recursos hídricos de forma convencional, setorizada e não adaptado a controlar o 
complicado balanço hídrico (em algumas bacias), a contaminação das águas e o conflito de entre os diversos usuários que se agravaram nos últimos anos. Não contempla a interdependência entre todos os usuários.

Mais recentemente, em janeiro de 1997, foi sancionada a Lei 9.433 que trata da gestão dos recursos hídricos. Ela define a bacia hidrográfica como unidade de gerenciamento e um sistema de gestão integrado. O Comitê da Bacia, formado pelos setores usuários da água da bacia, agentes governamentais, entidades não governamentais e representantes da comunidade em geral, toma as decisões referentes ao uso da água.

Assim sendo, informações sobre a quantidade consumida de água são de suma importância na gestão dos recursos hídricos e o principal objetivo deste trabalho é o de desenvolver um modelo para auxiliar na previsão de crescimento de seu consumo nos diversos setores e de quais fatores influencia esse crescimento.

Este trabalho consta de 7 capítulos, incluindo esta introdução. No segundo capítulo é feita uma descrição do recurso em questão, desde a legislação ao histórico do abastecimento em Piracicaba. O terceiro capítulo trata da teoria do consumidor e como a água entra nessa teoria. A revisão bibliográfica sobre módulos de demanda com estrutura de cobrança em blocos e seus problemas de estimação são apresentados no capítulo quatro. $O$ quinto capítulo apresenta a metodologia a ser usada, bem com as variáveis a serem consideradas no modelo. No sexto capítulo são apresentados os resultados dos modelos estimados e, as conclusões estão no capítulo sete. 


\section{A ÁGUA}

A água é um elemento químico simples, porém sem ela, a vida na terra não existiria como é hoje conhecida. Ela tem grande capacidade de absorver e trocar calor. Sendo a maioria das águas levemente ácidas, dissolvem uma variedade de componentes, como sais e minerais. A água reage com componentes orgânicos complexos, por exemplo, os aminoácidos e é importante para diversos processos físicos e biológicos que envolvem estocagem ou movimento, devido a sua tensão superficial (Rutkowski, 1999).

Fazendo parte de todas as manifestações da vida, a água representa $70 \%$ do corpo humano e está presente no interior e exterior de qualquer célula. Alguns organismos podem viver sem oxigênio, mas nenhum ser vivo conhecido é capaz de viver sem água.

O suprimento de água doce, em quantidade e qualidade, pode definir o padrão de desenvolvimento de uma região (Rutkowski, 1999). O desenvolvimento da agricultura e da sociedade sempre esteve vinculado ao controle da água. As civilizações do antigo Egito, da China, da Índia e da Mesopotâmia, chamavam-se 'civilizações hidráulicas', tendo sua ascensão e queda vinculada ao uso e abuso da água (Drew, 1986).

O uso da água pelo homem varia no tempo, assim como a sua quantidade demandada. A sociedade urbano-industrial tem gerado um grande crescimento na demanda hídrica, obrigando uma procura contínua por novas fontes hídricas. Toda atividade urbana - residencial, comercial e industrial - 
depende da existência da água para atender suas necessidades no uso direto e indireto (Rutkowski, 1999).

Diversos são os usos para a água doce, como higiene, alimentação, transporte, lazer e processos produtivos industriais, comerciais e agrícolas. Para cada atividade, existe a necessidade de água em quantidade e qualidade diferenciada. Na geração de energia elétrica, a água não pode conter poluentes corrosivos e é preciso em grande quantidade para acionar as turbinas. No lazer, a demanda é para água isenta de elementos químicos e biológicos nocivos à saúde. Para navegação e transporte, a necessidade é por volume e atracadouros adequados para diferentes embarcações. A irrigação necessita de considerável volume de água de boa qualidade (para o cinturão-verde usa-se até água tratada), sendo este uso altamente consuntivo ${ }^{7}$. Nas industrias, a água pode ser incorporada ao produto final (uso consuntivo) ou ao processo produtivo, como caldeiras e sistemas de refrigeração. Na higiene humana e animal e na dessedentação, a quantidade de água usada depende dos hábitos sociais (Rutkowski, 1999).

O crescimento e a concentração populacional nas áreas urbanas aumentam os conflitos entre as necessidades humanas e as do ecossistema natural. Uma região com precipitação menor do que 1000 mm/ano apresentam sérias limitações para a produção alimentar, o desenvolvimento econômico e a conservação ambiental (Nebel e Wright, 1988).

Obras de construção civil demandam areia e cascalho retirados dos leitos e margens de corpos d'água e impermeabilizam extensões variadas de solo. Para o abastecimento de água tratada, a água doce á captada e aduzida para tratamento, armazenagem e distribuição; depois de usadas, são aduzidas

\footnotetext{
${ }^{7}$ Uso consuntivo refere-se aquele em que parte ou total da água captada não retorna aos mananciais de origem.
} 
para tratamento (nem sempre) e retorno aos corpos d'água ${ }^{8}$, muitas vezes com qualidade inferior (Rutkowski, 1999).

A água é o solvente universal e meio de transporte, sendo usada para evacuação de detritos humanos e resíduos industrias. Devido à relativa facilidade de grandes intervenções nos recursos hídricos, a humanidade tem modificado os sistemas naturais provocando impactos de três ordens: mudanças na superfície da terra, poluição e retiradas consumptivas (Rutkowski, 1999).

Algumas mudanças na superfície da terra aumentam o fluxo de escoamento superficial devido à impermeabilização do solo. Assim, a diminuição da percolação acaba provocando enchentes e erosão. A poluição lançada na atmosfera pode precipitar na superfície como chuva ácida e juntamente com os produtos químicos usados na superfície, podem lixiviar para os depósitos subterrâneos. A irrigação, o consumo humano e a reversão de águas entre bacias hidrográficas têm caráter consuntivo, alterando as relações locais (Rutkowski, 1999).

A água é um recurso natural de múltiplos usos, essencial à vida, promove paisagem e lazer, é insumo para produção de inúmeras atividades agrícolas e industriais. Cobre três quartos da superfície do planeta, com um volume total de 1.386 milhões de $\mathrm{km}^{3}$, tendo permanecido constante nos últimos 500 milhões de anos $^{9}$ (Rebouças, 1999). Abaixo da superfície, infiltrada na terra, existem cerca de 4 milhões de $\mathrm{km}^{3}$ de água, permeando solos e rochas. Existem ainda cerca de $5.000 \mathrm{~km}^{3}$ de água na atmosfera, em sua maior parte na forma de vapor (Rutkowski, 1999).

\footnotetext{
${ }^{8}$ Às vezes esse retorno não é na microbacia original.

${ }^{9}$ As quantidades estocadas nos diferentes reservatórios individuais de água podem variar ao longo do tempo. Durante a Grande Idade do Gelo, a massa de gelo retirou 47 milhões de $\mathrm{km}^{3}$ de água dos oceanos para os continentes. Esse volume de água é quase o dobro da existente nos continentes.
} 
A água salgada, contida em mares e oceanos, representa $97,2 \%$ do volume total disponível na face da terra. Do restante, $2,15 \%$ estão nas geleiras e capotas polares, $0,31 \%$ são águas subterrâneas profundas (ainda inacessiveis com a tecnologia atual) e somente $0,34 \%$ estão na forma de rios, lagos, reservatórios subterrâneos acessíveis (Cabral, 1998).

A água é irregularmente distribuída entre regiões e continentes, como pode ser visto na Tabela 2.

Tabela 2. Distribuição de Água por Continente no Planeta.

\begin{tabular}{lc}
\hline Continente & $\mathrm{Km}^{3}$ \\
\hline Oceania & 24 \\
Europa & 76 \\
Árrica & 184 \\
América do Norte & 236 \\
Ásia & 533 \\
América do Sul & 946 \\
\hline
\end{tabular}

Fonte: Atlas do Meio Ambiente, Embrapa, 1994. In: Galvão (2000).

A hidrosfera (espaço hídrico) é constituída de duas partes: a primeira é a água que está aprisionada na forma de geleiras e glaciais e a segunda parte, a água que flui pelo planeta através de processos físicos de evaporação/ transpiração e precipitação. A evaporação ocorre pela absorção de energia luminosa, enquanto a precipitação libera energia potencial. Esse processo é denominado ciclo hidrológico, fonte de água doce do planeta e de purificação, como pode ser visto na Figura 1. São três os lugares de armazenamento da água no ciclo hidrológico: atmosfera, superfície terrestre e subsolo (Rutkowski, 1999).

A água, como todo recurso, possui quatro dimensões: quantitativa, qualitativa, temporal e espacial (Randall, 1987). A quantidade é medida em volume ou massa, e está relacionada com a disponibilidade do recurso. Ela pode ainda ser valorizada pela reserva, capacidade de renovação e facilidade de extração. A qualidade da água é dada por um conjunto de parâmetros, como 
características físico-químicas e organolépticas, parâmetros biológicos, microbiológicos e visual. A dimensão temporal está relacionada com fluxo e extração; e a espacial, com localização, distância e dificuldade de acesso.

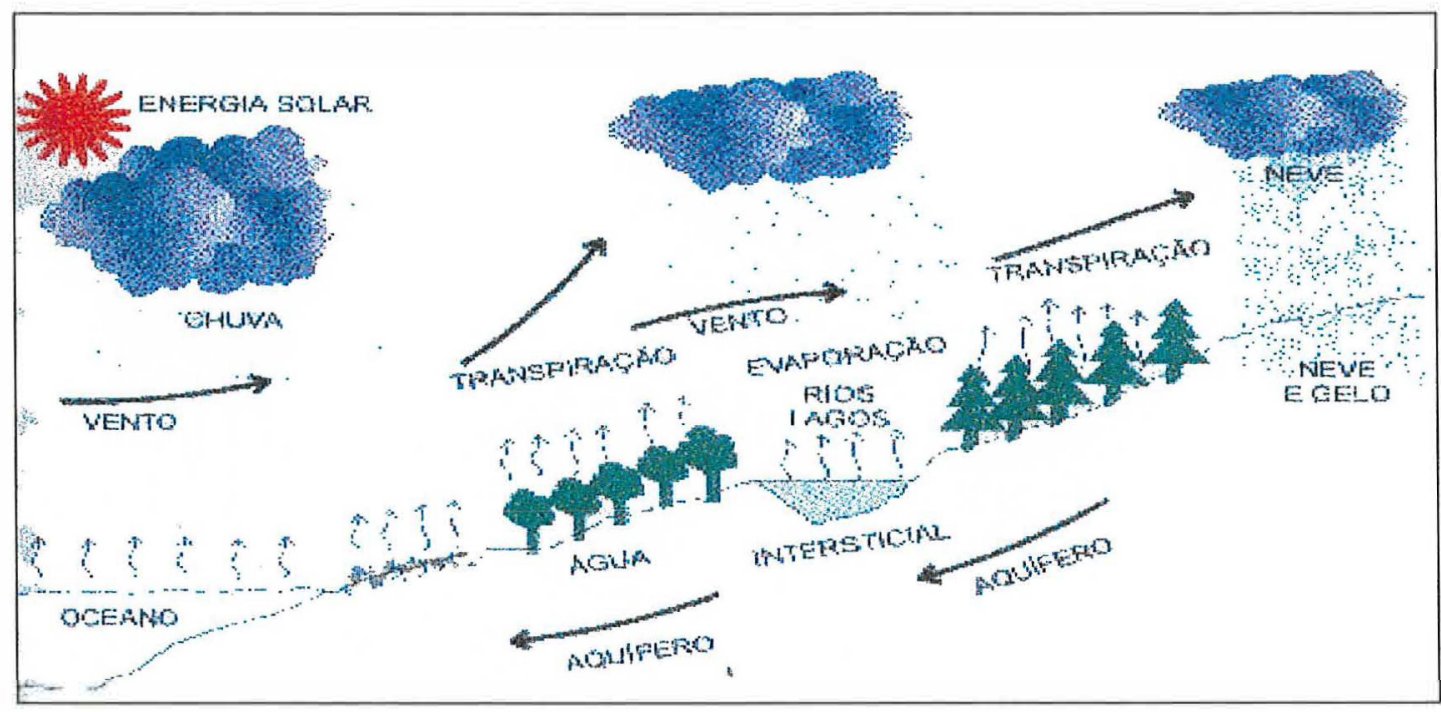

Figura 1. Ciclo Hidrológico.

Fonte: Hylckama, 1975.

A água pode ter dois tipos de uso. O uso consuntivo há redução efetiva da disponibilidade de água. Estão nesta categoria o a maior parte do uso doméstico, industrial e para irrigação. No consumo doméstico, somente $70 \%$ da água captada retorna aos mananciais e somente uma pequena porcentagem ${ }^{10}$ do esgoto urbano passa por algum tratamento antes de retornar aos rios, afetando a qualidade (Romano, 1998). No uso industrial, alguns setores geram grande quantidade de poluição ${ }^{11}$. A agricultura irrigada é a atividade que

${ }^{10}$ Segundo a Associação Brasileira de Engenharia Sanitária e Ambiental - Abes, somente 5\% dos esgotos urbanos passam por algum tratamento no Brasil (Pereira Jr., 1998). Romano em entrevista para o Agroanalysis, diz que $10 \%$ dos esgotos urbanos gerados são devidamente tratados.

${ }^{11} \mathrm{~A}$ indústria de açúcar e álcool produz 12 litros de vinhaça para cada litro de álcool, que não retornam ao curso d'água. Os setores de papel e celulose, frigoríficos, siderurgia e 
demanda água em maior quantidade e também é exigente em termos de qualidade, podendo causar outros danos se não for conduzida corretamente ${ }^{12}$.

O segundo, o uso não-consuntivo da água não reduz a disponibilidade do recurso hídrico, nem afeta diretamente a qualidade. São exemplos a navegação, geração de energia elétrica, natação, pesca, composição paisagística. Mas o uso não consuntivo pode criar externalidades ${ }^{13}$, como é o caso de construção de barragem para as usinas hidroelétricas ${ }^{14}$, ou vazamento de óleo na navegação.

Este estudo está interessado no uso consuntivo. A derivação é um exemplo de uso consuntivo do ponto de vista espacial, pois um fato ocorrido na cabeceira de um rio refletirá em todo o curso. Esse é o problema de distribuição de água entre as cidades. A extração ou captação de água a montante afeta a disponibilidade hídrica, em quantidade ou qualidade.

Existem três diferentes valores que podem ser associados a um bem ou serviço ambiental, e em especial aos recursos hídricos, que șão: valor de uso, valor de opção e valor de existência. Valor de uso vem do uso direto do serviço, que sozinho ou combinado, cria satisfação. Já o valor de opção é o valor atribuído quando alguma facilidade ou serviço estará disponível no futuro e alguma pessoa racional está disposta a pagar para ter essa opção de uso no futuro. $O$ valor de existência é derivado da satisfação que as pessoas têm pelo simples fato daquele recurso existir e estar sendo preservado (Randall, 1987).

12 Pode haver carreamento de fertilizantes e defensivos agrícolas, assoreamento dos lençóis freáticos e cursos d'água. Afeta também a temperatura, velocidade da água, fluxo, entre outros.

13 Externalidade é quando uma atividade econômica resulta em custos ou benefícios econômicos que não são apropriado pela ativadade que causou.

${ }^{14} \mathrm{~A}$ barragem pode trazer problema por impedir a passagem de sedimentos, impedir a subida dos peixes para a desova e afeta a fauna e flora aquática. 
O espaço geográfico também exerce influência na água, pois as diferenças climáticas, geológicas, topográficas, entre outras existentes entre regiões, podem alterar a sua quantidade e qualidade. A unidade de estudo ideal para manejo de recurso hídrico é a bacia hidrográfica, pois a água precipitada dentro de uma bacia, sofre uso consuntivo ou escoa por cursos de água até desembocar no leito do curso principal (Giansanti, 1993).

A heterogeneidade da água e diversidäde de seu uso pressupõe distintos enfoques analíticos em função do uso considerado (Pinheiro, 1998). A "água destinada para determinado uso interfere nas disponibilidades para outros, os usos não são independentes. Neste caso, o valor e o preço da água poderiam ser analisados sob óptica de um modelo amplo, de equilíbrio geral, onde fossem considerados todos os elementos da economia, inclusive externalidades. Mas, se o objetivo da análise focaliza apenas um uso, pode ser considerado o modelo de equilíbrio parcial" (Pinheiro, 1998).

\subsection{Aspectos Legais}

A primeira legislação sobre a gestão de recursos hídricos no Brasil nasceu no século XVI, com a "Ordenações Filipinas", ainda no período colonial e com Portugal sob domínio da Espanha (Cabral, 1998). Os instrumentos continham dispositivos específicos sobre gestão da água e previa punições para quem a degradasse ou nela jogasse dejetos. Porém, elas nunca foram aplicadas no Brasil.

O Código das Águas de 1934, antecipou a necessidade de preservação dos recursos hídricos, muito antes de iniciarem-se os problemas e a preocupação nacional com o meio ambiente. Trata-se de um instrumento legal, que continuou atual mesmo com o desenvolvimento econômico e social das últimas décadas. O Código define a questão do aproveitamento das águas quanto aos múltiplos usos; assegura o uso gratuito para as primeiras necessidades e introduz o princípio da cobrança. Garante a preferência da 
derivação para o abastecimento da população e o uso mediante concessão. Prevê responsabilidades e critérios para ações que causem danos a água, bem como prevê a revogação de seu uso e obriga a harmonizar os interesses da agricultura com o da indústria (Cabral, 1998).

Entretanto, a falta de regulamentação da maioria de seus artigos (204 artigos no total) fez com que não fosse plenamente aplicado. Somente foi regulamentada a parte que tratava do aproveitamento energético. A terceira parte do Código, do artigo 139 em diante, é dedicada às forças hidráulicas. Tem a preocupação de estabelecer que todos os aproveitamentos de energia hidráulica satisfaçam as exigências de interesse geral: a) da alimentação e das necessidades das populações ribeirinhas; b) da salubridade pública; c) da navegação; d) da irrigação; e) da proteção contra inundações; f) da conservação e livre circulação do peixe; g) do escoamento e rejeição das águas. Nem sempre essas exigências foram compridas e, por falta de uma completa regulamentação, houve domínio do setor energético sobre os demais (Campos, 1998). Como 95\% da energia elétrica brasileira vem do potencial hidroenergético, este setor foi se estruturando, regulamentando, enquanto os outros setores não o fizeram. Por essa razão, às vezes tem-se a impressão que - Código foi feito somente para o setor energético. A pressão dos outros setores só pode ser sentida a partir da década de 70 , quando iniciaram os problemas de poluição e escassez de água.

Para a nova legislação, buscou-se uma solução que contemplasse as diferenças das regiões do país e a interdependência de todos os setores usuários da água, promovendo uma gestão descentralizada e participativa, permitindo a interação entre pessoas, grupos, empresas, poder público, organizações governamentais e não-governamentais.

Baseada na experiência internacional e na discussão interna surgiu um sistema integrado de gestão. Assim em 8 de janeiro de 1997, foi aprovada a Lei 
9.433, que instituiu a Política Nacional de Recursos Hídricos, complementando o Código das Águas, cujos princípios básicos consistem em:

a) Adotar a bacia hidrográfica como unidade de planejamento, colocando a demanda e as disponibilidades em confronto;

b) Introduzir o conceito de usos múltiplos, com todos os usuários com igual acesso aos recursos hídricos, sendo o abastecimento de água as populações a única prioridade;.

c) Reconhecer a água como bem limitado, finito e vulnerável;

d) Reconhecer o valor econômico da água, servindo de base para a cobrança com base no princípio usuário-pagador e/ ou usuário-poluidor; e,

e) Propor uma gestão descentralizada e participativa, onde as decisões são tomadas dos níveis hierárquicos mais baixos para os mais altos. A decisão deve ser o mais próximo do problema possivel.

Para gerir esse sistema foram criados cinco instrumentos pela Lei 9.433. O primeiro é o Plano Nacional de Recursos Hídricos, que consolida os planos diretores de recursos hídricos no âmbito da bacia hidrográfica, permitindo mudanças de acordo com cada necessidade regional. $O$ segundo instrumento é a outorga de direito de uso dos recursos hídricos, onde é dada uma autorização, concessão ou permissão para fazer uso da água, conforme o caso. Ao mesmo tempo permite aos organismos gestores ter o domínio sobre os volumes comprometidos em cada corpo de água. O terceiro é a cobrança pelo uso da água, capaz de promover o equilíbrio entre a disponibilidade dos mananciais e as forças da demanda. $O$ quarto é o enquadramento em classes de usos preponderantes, estabelecendo uma racionalidade de uso, possibilitando o uso de águas de um padrão de qualidade inferior para usos menos nobres, preservando a água de melhor qualidade para usos mais 
nobres. Esse instrumento faz uma ligação entre a qualidade e quantidade do recurso, fortalecendo a relação entre gestão dos recursos hídricos e a gestão do meio ambiente. O último é o Sistema Nacional de Informações sobre Recursos Hídricos, encarregado organizar um banco de dados para cada manancial e de cada bacia. Através da informação, todos os setores envolvidos - os gestores, a sociedade civil e outros usuários de informações - podem opinar no processo de decisão.

Para uma gestão compartilhada do uso da água foram criados também novos organismos a partir da instituição desse sistema. São eles:

a) Conselho Nacional de Recursos Hídricos - órgão maior das decisões sobre recursos hídricos, a quem cabe decidir sobre questões nacionais;

b) Comitê de Bacia Hidrográfica - fórum de decisão no âmbito de bacia, que conta com a participação dos usuários, das prefeituras, da sociedade civil organizada e dos demais níveis de governo, formando o "parlamento das águas". É responsável pelo debate sobre programas a serem desenvolvidos;

c) Agência da Água - destinado a realizar as decisões tomadas nos comitês e administrar os recursos gerados pelo novo sistema. É seu o organismo técnico; e,

d) Organizações civis de recursos hídricos - entidades atuantes no setor de planejamento e gestão do uso de recursos hídricos.

A lei $n^{0} 9.433$ transforma a água em bem de domínio público (art. $1^{\circ}$, inciso I). O Estado incorpora os recursos hídricos em seu patrimônio, podendo cobrar pela outorga do consumo da água (Silva e Brito, 1999). "Estão sujeitos à outorga os diretos de derivação ou captação de parcela da água existente em um corpo de água para consumo final, inclusive abastecimento público, ou 
insumo de processo produtivo; extração de água de aqüifero subterrâneo para consumo final ou insumo de processo produtivo; lançamento em corpo de água de esgotos e demais resíduos líquidos ou gasosos, tratados ou não, com o fim de sua diluição, transporte ou disposição final; aproveitamento dos potencias hidroelétricos; outros usos que alterem o regime, a quantidade ou a qualidade da água existente em corpo de água" (Couto, 1999, p.19).

\subsection{Os Sistemas de Abastecimento}

Um problema extremamente grave para a saúde é a falta de saneamento básico. Esse é o caso para 1bilhão e 700 milhões de habitantes, quase $30 \%$ da população mundial. Outro dado preocupante é que a poluição das águas está associada a $33 \%$ das mortes em todo o planeta (Boyayan, 1998).

A água serve para veículo de doenças, se usada sem tratamento, causando um dano de cerca de US $\$ 400$ milhões anuais de recursos do Sistema Único de Saúde - SUS (Teixeira, 2000), além de responsável por $60 \%$ das internações hospitalares. No mundo, estima-se que 100 milhões de pessoas morram anualmente de doenças transmitidas pelas águas, como: tifo, dengue, malária, cólera, infecções diarréicas e esquistossomose (Boyayan, 1998).

No Brasil, estima-se que menos de $40 \%$ da população tenham água tratada adequadamente e $23 \%$ utilizam serviço de esgoto, gerando um aumento da mortalidade infantil (Teixeira, 2000). Parte desse problema está relacionado ao custo de cerca de US\$450para ligar uma casa à rede de água custa e de US\$ 800 para a conexão à rede de esgoto,.

Devido às necessidades de recuperação dos sistemas obsoletos e da ampliação da rede de atendimento ao crescente consumo, motivado pela 
expansão dos centros urbanos, verifica-se uma tendência mundial para a privatização de serviços de abastecimento ${ }^{15}$.

Dos 645 municípios paulista, 366 são atendidos pela Sabesp, 278 possuem serviços administrados por empresas municipais e, em Limeira, por empresa privada (Zioni, 2000).

Vários municípios estão tendo problemas com abastecimento urbano, começando pela capital paulista. A cidade cresceu em torno da nascente do rio Tiête e hoje a oferta desse e outros rios da região, atendem precariamente a quantidade demandada (Teixeira, 2000). Já, na década de 60 , em função da necessidade de maior quantidade de água para a região metropolitana de São Paulo, foi criado o Sistema Cantareira. O Sistema é composto por três grandes reservatórios na Bacia do rio Piracicaba (Jaguari, Cachoeira e Atibainha), interligados por túneis, permitem a transferência para São Paulo, de $31 \mathrm{~m}^{3} / \mathrm{s}$.

A construção do Sistema Cantareira trouxe problemas na quantidade e na qualidade da água da bacia do rio Piracicaba. A retirada de parte da vazão dos rios aumentou a concentração dos agentes poluidores.

\footnotetext{
${ }^{15}$ Sófia, capital da Bulgária, está em processo, Atlanta foi privatizada em 1999 e Grã-Bretanha já nos anos 80 são exemplos (Teixeira, 2000).
} 


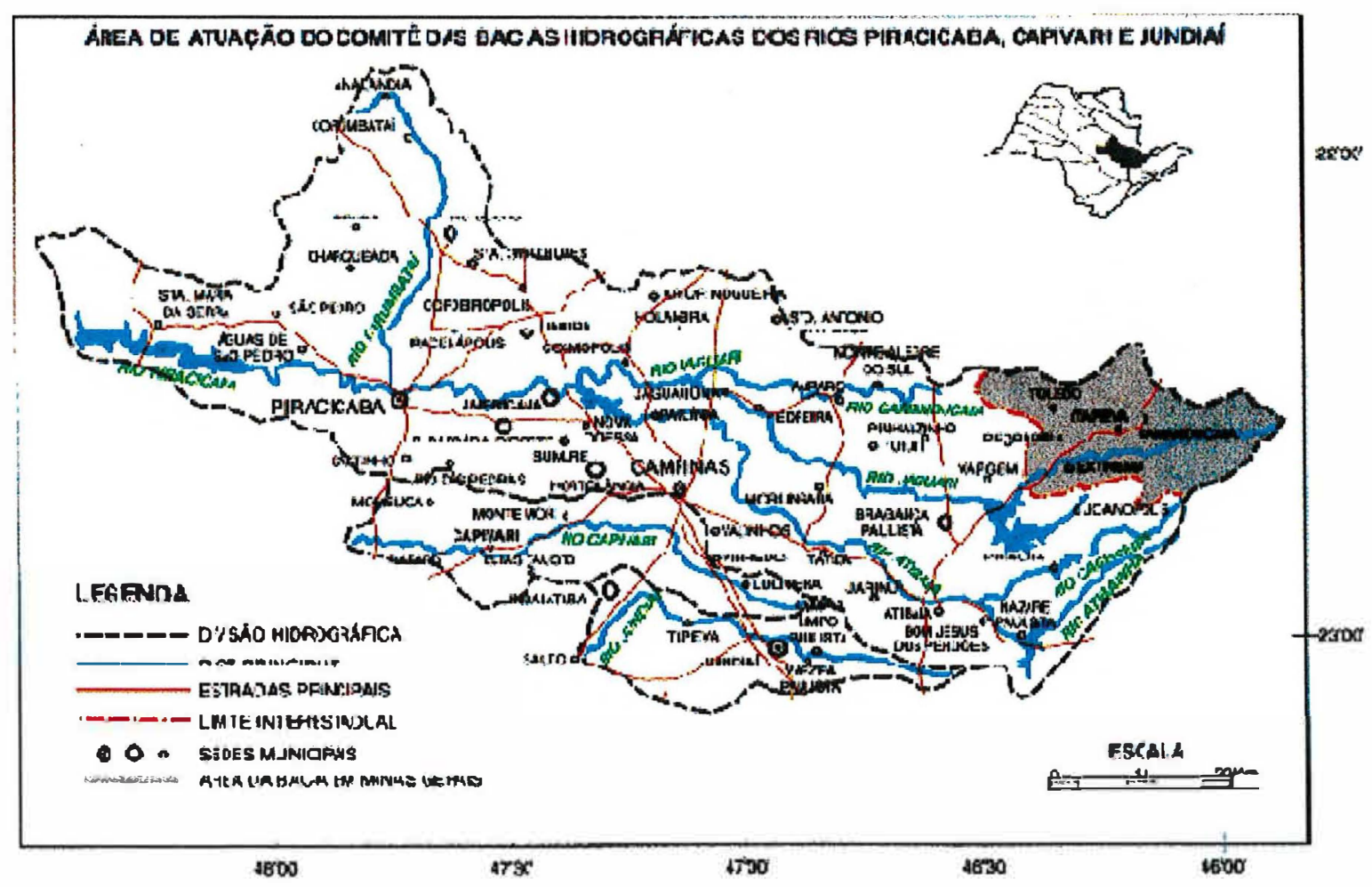

Figura 2. Mapa da Bacia dos Rios Piracicaba, Jundiaí e Corumbataí.

Fonte: Homepage do Comitê da Bacia Hidrográfica dos Rios Piracicaba, Capivari e Jundiaí.

\subsection{O Abastecimento em Piracicaba}

Na cidade de Piracicaba, a poluição crescente do rio, foi necessário buscar nova fonte de captação. Assim, foi feito um investimento para conseguir captar água junto ao rio Corumbataí, outro manancial de melhor qualidade, que fica a quilômetros de distância.

A cidade de Piracicaba sempre teve o rio Piracicaba como sua principal fonte de abastecimento público de água. Ele nasce na cidade de Americana, no encontro dos rios Atibaia e Jaguari. As nascentes do rio Jaguari localizam-se em Camanducaia, estado de Minas Gerais. O rio Atibaia é formado da junção dos rios Atibainha e Cachoeira. O Atibainha nasce nas proximidades de Nazaré Paulista e o Cachoeira, na região de Piracicaba, como mostra a Figura 2. 
O rio Piracicaba tem outros afluentes importantes como: Quilombo (que nasce em Campinas), Toledo (com nascente na região de Santa Bárbara D'Oeste), Corumbataí (originado em Analândia), ribeirão Anhumas (que nasce em Campinas), ribeirão Piracicamirim (nativo da região de Piracicaba), ribeirão Pinheiros (que nasce na região de Vinhedo), entre outros. A Bacia do rio Piracicaba possui uma superfície de 12.746 km2.

Em função da queda de qualidade da água do rio Piracicaba, em 1980, iniciou-se a construção do Sistema Corumbataí como altemativa ao sistema Piracicaba. Ele entrou em operação no ano de 1983. Inicialmente, o volume captado representava $33 \%$ da água consumida, crescendo até atingir os $100 \%$ nos dias atuais.

Piracicaba conta hoje com um sistema de abastecimento público que atende a praticamente $100 \%$ da população urbana. A rede atende a 86.338 ligações de água que demandam 105.000.000 litros de água por dia, para uma população estimada em cerca de 350.000 habitantes.

\subsection{O SEMAE}

Em maio de 1886, foi iniciada a construção do primeiro resenvatório de água, com capacidade de 2 milhões de litros, no bairro dos Alemães. Em 30 de abril de 1969, através da Lei no 1657, foi criado o SEMAE - Serviço Municipal de Água e Esgoto. Em agosto de 1969, Piracicaba já contava com inúmeros projetos de rede de esgoto e de fornecimento de água. Com isso a autarquia ganhava autonomia econômica, financeira e administrativa.

A cidade tem hoje com três Estações de Captação: duas no rio Piracicaba e uma no rio Corumbataí. Porém, devido à qualidade e vazão do rio Piracicaba, somente a estação do Corumbataí está em operação. O sistema de abastecimento da cidade está informatizado, sendo possível remanejar água de um resenvatório para outro. 
Em função da análise dos diversos indicadores dos rios Piracicaba e Corumbataí, de estudo hidrológico, de projeção de crescimento populacional e de outros instrumentos, o SEMAE concluiu que o Corumbataí tomar-se-ia o principal manancial para o abastecimento público.

No período de operação conjunta com os rios Piracicaba e Corumbataí , acompanhou-se os principais indicadores de qualidade e quantidade dos dois mananciais. O Corumbataí possui $136,5 \mathrm{~km}$ de extensão, nasce no município de Analândia e deságua no rio Piracicaba. Recebe menos esgotos domésticos, industriais e apresenta menor índice de coliformes fecais em comparação às águas do Piracicaba.

O Corumbataí não tem águas represadas, ou seja, há ausência de algas, as quais liberam substâncias que provocam odor e gosto. De acordo com a Companhia Estadual de Tecnologia de Saneamento Ambiental (Cetesb), a média de Oxigênio Dissolvido (OD) no Corumbataí é de 4,0 a 6,0 miligramas/litro. Média considerada "excelente", já o rio Piracicaba, em épocas de estiagem, não ultrapassa a média de 1,0.

O Corumbataí apresenta-se até então, bem melhor que o Piracicaba. Entretanto, existe uma tendência de queda da qualidade ao longo dos anos, que somado com a crescente demanda, não só para uso doméstico, como também industrial e agrícola poderão comprometer a disponibilidade e a qualidade, principalmente nos períodos de estiagem.

Todos os dados hidrológicos e de qualidade da água demonstram a urgente necessidade de uma ação efetiva em toda a Bacia do Corumbataí, para preservar a qualidade de sua água e manter sua disponibilidade de vazão mínima suficiente para atender toda a demanda da bacia. 


\subsection{O Sistema de Abastecimento de Água de Piracicaba}

O abastecimento de água em Piracicaba utiliza-se de dois sistemas produtores: o rio Piracicaba e o rio Corumbataí .

As Estações de Tratamento de Água (ETAs) 1 e 2 estão localizadas num mesmo terreno, na rua Luiz de Queiroz. O processo de tratamento de água em Piracicaba é do tipo clássico, contando com floculadores, decantadores e filtros.

O terceiro ponto de captação pertence ao Sistema Corumbataí, localizase junto à margem esquerda do rio, à montante da Usina Costa Pinto. 


\section{TEORIA DO CONSUMIDOR}

A economia é baseada no princípio de vontade ilimitada. Coletivamente, as pessoas desejam mais do que a economia pode prover e a limitação está entre a vontade e a habilidade da economia de poder prover (Ruffin e Gregory, 1983).

A curva de demanda $D$ relaciona a quantidade que os consumidores desejam comprar para cada preço unitário que tenham que pagar (Pindyck e Rubinfeld, 1994). Em geral, ela tem inclinação negativa, pois existe uma relação inversa entre o preço de um bem e a quantidade demandada, mantendo os demais fatores constante. (Figura 3.)

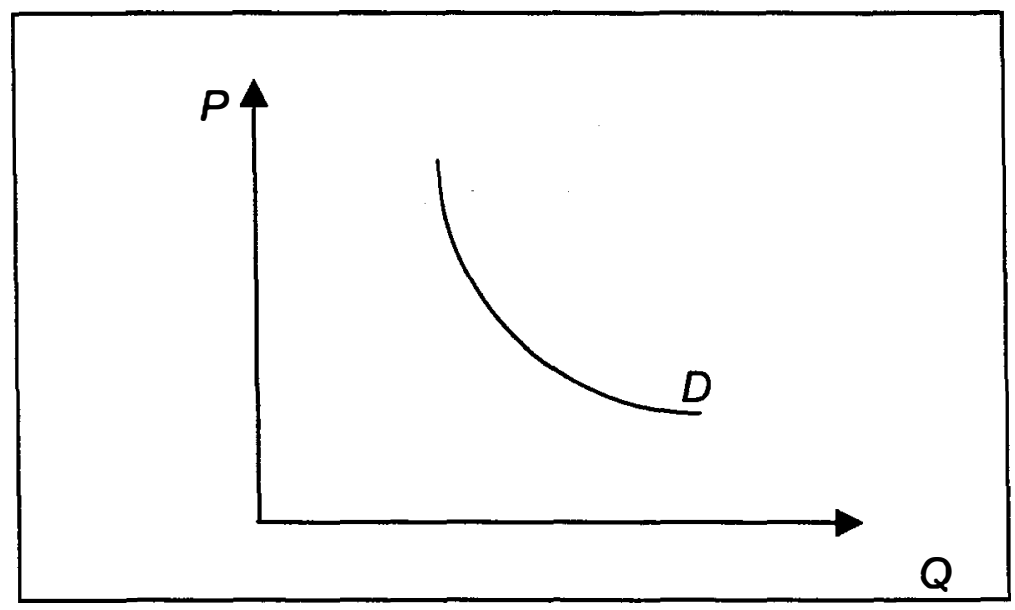

Figura 3. Curva de demanda $D$, que relaciona preço $P$ e quantidade $Q$. 
A quantidade demandada é a quantia de um bem ou serviço que o consumidor está pronto para comprar a um determinado preço. Desse princípio nasce a curva de demanda individual. A soma das demandas individuais irá formar a curva de demanda de mercado (Ruffin e Gregory, 1983).

O modelo do comportamento do consumidor é baseado no princípio de que o consumidor irá alocar sua renda de maneira a conseguir máxima satisfação. Demanda e desejo são coisas diferentes em economia. $O$ desejo não considera a limitação orçamentária e a demanda sim. Demanda denota aqueles bens e serviços que o consumidor está disposto a comprar dado os preços relativos e seu nível de renda (Ruffin e Gregory, 1983).

Os princípios que dão a base para a demanda do consumidor estão relacionados com o comportamento do consumidor e do mercado. A partir do processo de tomada de decisão dos consumidores, isto é, de acordo com sua preferência e sua renda disponível (restrição orçamentária), é construída a curva de demanda.

\section{1 - Preferência do consumidor: Pressupostos}

Cesta de mercado é o conjunto de uma ou mais mercadorias, matematicamente expressa por:

$$
Q \in R_{+}^{n}, \quad Q=\left[q_{1}, q_{2}, \cdots, q_{n}\right]
$$

onde $q_{i}$ é a quantidade do bem $i$, na cesta $Q$.

A teoria do comportamento do consumidor está baseada em três pressupostos básicos a respeito das preferências dos consumidores: 
Completa: Os consumidores são capazes de comparar e ordenar duas cestas quaisquer, isto é, para todo $Q_{a}$ e $Q_{b}$ em $Q$, ou $Q_{a} \succeq Q_{b}{ }^{16}$ ou $Q_{b} \succeq Q_{a}$ ou ambos. $\succeq$

Reflexiva: Qualquer cesta é ao menos tão boa quanto ela própria, ou seja, para todo $Q_{a}$ em $Q, Q_{a} \succeq Q_{a}$.

Transitiva ${ }^{17}$ : Se o consumidor prefere uma cesta $Q_{a}$ em vez da cesta $Q_{b}$, e prefere a cesta $Q_{b}$ em vez da $Q_{c}$, então ele prefere a cesta $Q_{a}$ à $Q_{c}$.

Esses pressupostos predeterminam o conjunto de opção, denominado ordem de preferência. Outros pressupostos são necessários para formar um conjunto de axiomas de escolha.

Contínua ${ }^{18}$ : Este pressuposto é necessário para evitar descontinuidade do comportamento do consumidor, isto é, se $Q$ é uma seqüência de cestas de consumo e que todas são tão boas quanto a cesta $Q^{y}$, e se aquela seqüência converge para $Q^{*}$, então $Q^{*}$ é tão boa quanto $Q^{y}$. Ou seja, para todo $Q^{y}$ em $Q$, os conjuntos $\left\{Q^{i}: Q^{i} \succ Q^{y}\right\}$ e $\left\{Q^{i}: Q^{i} \succeq Q^{y}\right\}$ são conjuntos fechados. E, sendo assim, $\left\{Q^{i}: Q^{i} \succ Q^{y}\right\}$ e $\left\{Q^{i}: Q^{i} \prec Q^{y}\right\}^{19}$ são conjuntos abertos.

\footnotetext{
${ }^{16}$ A expressão $Q_{a} \geq Q_{b}$ significa que o consumidor pensa que a cesta $Q_{a}$ é pelo menos tão boa quanto a cesta $Q_{b}$.

${ }^{17}$ Ou consistente.

${ }^{18}$ Ou monotônica.

${ }^{19}$ A expressão $\{Q: Q \succ Q\}$ significa que a cesta $Q_{a}$ é preferida à cesta $Q_{b}$.
} 
Não saciedade: Um consumidor sempre vai preferir a cesta que contenha uma maior quantidade de pelo menos um bem ou serviço. Dado qualquer $Q^{x}$ em $Q$ e qualquer $\varepsilon>0$, então existe algum $Q$ em $Q$, o qual $\left|Q^{x}-Q^{y}\right|<\varepsilon$ se $Q^{y} \succ Q^{x 20}$.

Convexa: A inclinação da curva de indiferença aumenta (torna-se menos negativa) ao longo da curva. Ou seja, dado $Q^{x}, Q^{y}$ e $Q^{z}$ em $Q$, tal que $Q^{x} \succeq Q^{z}$ e $Q^{y} \succeq Q^{z} \cdot t Q^{x}+(1-t) Q^{y} \succ Q^{z}$ para todo $0 \leq t \leq 1$.

Não cruzam: Dado que as preferências são transitivas, não pode haver interseção entre curvas de indiferença.

Preferência é a avaliação pessoal dos bens e serviços, independentes de renda ou preço. Uma maneira de descrever as preferências dos consumidores é através de cesta de mercado, descrita acima. A teoria da demanda é baseada na existência de preferências individuais. $O$ consumidor tem a possibilidade de escolher entre cestas alternativas (por exemplo, $Q$ e $Q$ ).

Pode-se representar os gostos e preferências dos consumidores por um conjunto de curvas de indiferenças. Uma curva de indiferença representa todas as combinações de cestas de mercado que trazem o mesmo grau de satisfação a uma pessoa (Pindyck e Rubinfeld, 1994). Um mapa com as curvas de indiferença é a representação das preferências dos consumidores, mostra a parte central da teoria do consumidor. A curva de utilidade convexa está

$20|x-y|$ significa distância euclidiana. 
associada ao pressuposto neoclássico de taxa marginal de substituição decrescente.

A utilidade indica o nível de satisfação ou preferência do consumidor para uma cesta de mercado. Ao longo de uma curva de indiferença, existe uma satisfação única, portanto, a mesma utilidade. Curvas de indiferenças mais altas estão relacionadas com maiores utilidades que curvas mais baixas.

\section{2 - O Conjunto de Oportunidades}

\subsection{1 - A restrição orçamentária}

No problema de maximização da preferencia, o conjunto de alternativas possiveis é justamente o conjunto de todas as cestas de mercado que satisfazem a restrição orçamentária do consumidor.

O consumidor não pode comprar tudo que deseja pois existe uma restrição econômica, sendo ela exógena. O consumidor dispõe de um orçamento ou uma renda $y$, num determinado período de tempo, para adquirir as mercadorias disponíveis. Pode-se adquirir qualquer quantidade não negativa do bem $i, q_{i}$, ao preço fixo $p_{i}$. Então, a restrição orçamentária pode ser escrita como:

$$
y \geq \sum_{i=1}^{n} p_{i} q_{i}
$$

A linha de restrição orçamentária para o caso de $n=2$ é representada na Figura 4. Ela relaciona todas as combinações de quantidade do bem 1 e 2 
que o consumidor consegue comprar. Qualquer quantidade dentro da área $A O G$ é possível de ser adquirida com a renda disponível.

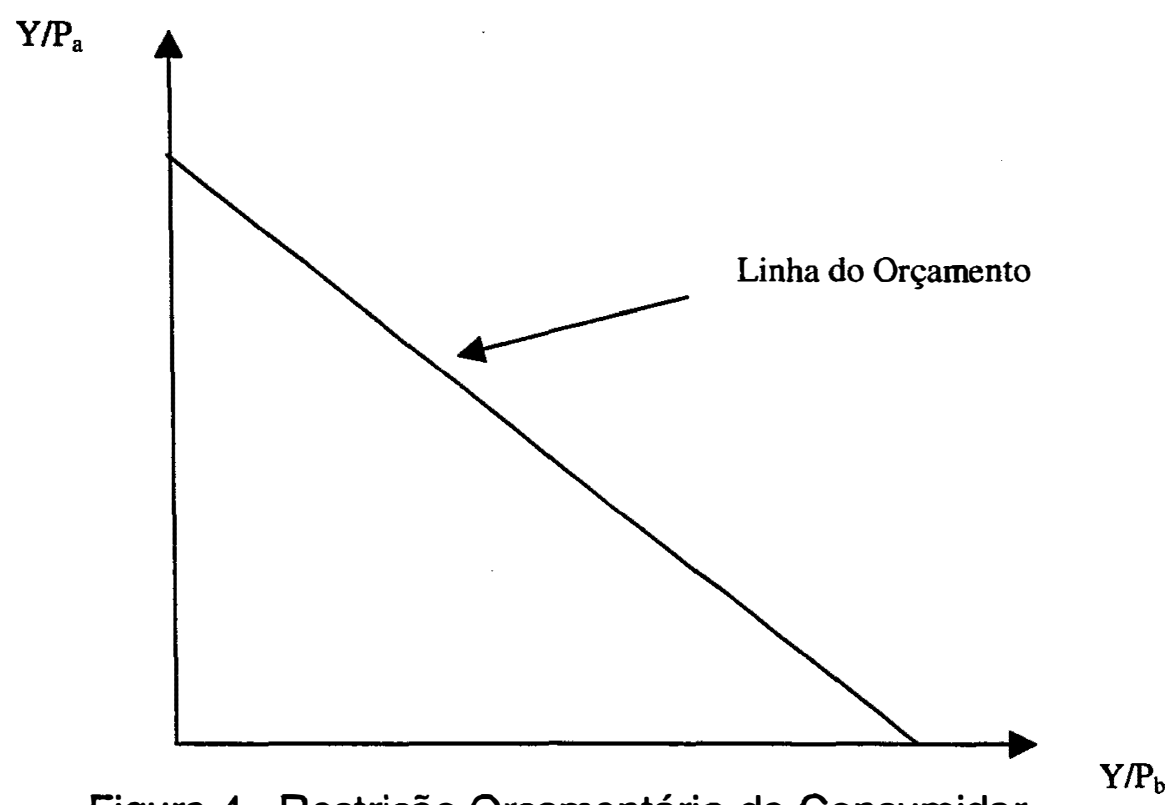

Figura 4 . Restrição Orçamentária do Consumidor.

Quando o preço de um bem não é fixo, a restrição orçamentária deixa de ser linear. Se o consumidor enfrenta uma tarifa com duas ou mais partes, isto é, estrutura tarifária em blocos, a restrição orçamentária deixa de ser linear (Deaton e Muellbauer, 1980). No caso de tarifa em blocos decrescentes, com as primeiras unidades sendo pagas a uma taxa mais alta, a forma da curva de restrição orçamentária torna-se truncada (Figura 5). 


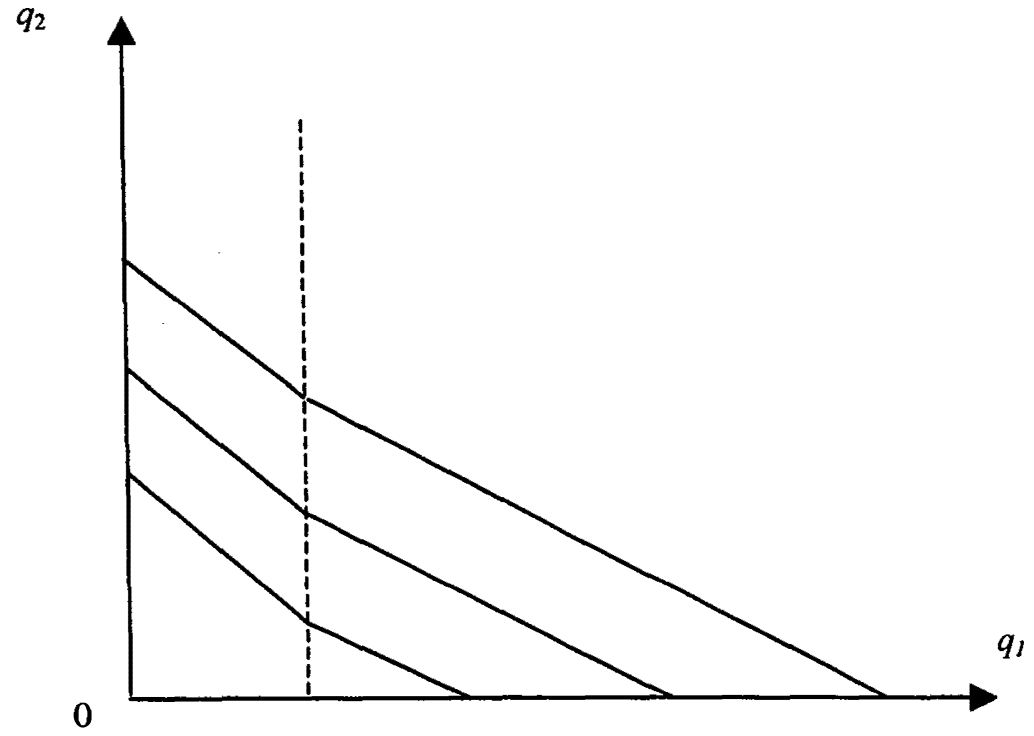

Figura 5. Restrição orçamentária com tarifas em dois blocos decrescentes.

Fonte: Deaton e Muellbauer (1980).

É importante salientar ainda que o comportamento do consumidor é dado pela restrição orçamentária percebida pelo tomador de decisão. A perfeita informação não é viável para todos os indivíduos e nem sempre tem o mesmo custo. Se a estrutura tarifária for em blocos, é necessário conhecer qual o preço relevante para o consumidor na decisão de consumo (Deaton e Muellbauer, 1980). 


\section{3 - Equilíbrio do Consumidor}

A hipótese básica é que o consumidor faz sua escolha de forma racional ${ }^{21}$. Ele decide a combinação de mercadorias, visando maximizar o grau de satisfação que poderá obter, considerando o orçamento que dispõe.

Duas condições são necessárias para maximizar a satisfação do consumidor. A primeira é que a combinação de mercadorias deverá estar localizada na linha de orçamento. A segunda é que ela deve estar localizada na curva de indiferença mais alta, isto é, deverá estar maximizando a satisfação do consumidor.

O problema de maximização da preferência pode ser resumido em :

$$
\operatorname{Max} U\left(q_{i}\right)
$$

$$
\text { Sujeito a: } \quad p_{i} q_{i} \leq y
$$

O valor $q_{i}^{*}$ que soluciona este problema pode ser obtido pela solução da seguinte equação de Lagrange

$$
£=u(q)-\lambda(p q-y)
$$

onde $\lambda$ é $\circ$ multiplicador de Lagrange. Diferenciando a equação acima, para cada $q_{i}$, encontrarmos a condição de primeira ordem:

$$
\frac{\partial u(q)}{\partial q_{i}}-\lambda p_{i}=0 \quad \text { para todo } \quad i=1, \cdots, n
$$

${ }^{21}$ A racionalidade usada nesse capítulo é a da teoria neoclássica, onde o custo de informação é zero e o consumido conhece o preço de todos os bens e serviços e sua renda. 
Assim, juntando as $n$ equações acima com a restrição orçamentária:

$$
p q-y=0
$$

temos $n+1$ equações para $n+1$ incógnitas. Se existir solução, está é chamada de demanda Marshaliana e pode ser representada por

$q_{i}^{*}=q_{i}(p, y) ; \quad i=1, \ldots n$.

\section{4 - Especificações}

Muitos estudos estimam modelos de demanda, através de séries temporais com uma equação do tipo:

$$
\log q_{i}=\alpha_{1}+e_{i} \log y+\sum_{n} e_{i n} \log p_{n}+u
$$

onde:

$\alpha_{1}$ é o termo constante;

$q_{i}$ é a quantidade demandada do bem $i$;

$e_{i}$ é a elasticidade renda do bem $i$;

$e_{i n}$ é a elasticidade preço cruzada do bem $i \operatorname{com}$ o bem $n$; e

$u$ é o erro aleatório. 


\section{5 - Problemas com Estrutura Tarifária em Blocos}

Neste estudo em particular, o interesse é centrado na demanda pelos serviços de abastecimento de água, onde a estrutura de cobrança adotada é o tradicionalmente chamado Estrutura Tarifária em Blocos Crescentes. Nessa estrutura, os preços aumentam de acordo com faixas de consumo. No primeiro bloco, até $10 \mathrm{~m}^{3}$, a tarifa cobrada é a máxima, pagando sempre pelo consumo total do bloco.

Uma das dificuldades na estimação da demanda por água é que a sua participação percentual na despesa total da família é reduzida, não sendo um gasto significativo para o consumidor.

Para a presente analise, postula-se que o consumidor tem apenas duas opções de consumo: água, $q_{a}$, e outros bens, $q_{b}$. O preço dos outros bens é representado por $P_{b}$, a renda é $y$, o preço da água é $P a=\left\{\begin{array}{ccc}k & \text { se } & 0<q_{a} \leq \bar{q}_{a} \\ q_{a} k & \text { se } & q_{a}>\bar{q}_{a}\end{array}\right.$ e o valor da despesa $V a=\left\{\begin{array}{c}k \bar{q}_{a} \text { se } 0<q_{a}<\bar{q}_{a} \\ k \bar{q}_{a}+q_{a} k\left(q_{a}-\bar{q}_{a}\right) \text { se } q_{a}>\bar{q}_{a}\end{array}\right.$.

No caso de tarifas crescentes, $\alpha>1$. O valor da despesa não é linear, e a restrição orçamentária também é não linear. Nesse tipo de estrutura tarifária, não existe interesse em se consumir abaixo de $\bar{q}$, pois o valor a ser pago é $k \bar{q}_{a}$ qualquer consumo até este valor. Outra característica desta estrutura em blocos é o subsídio dado pela expressão $k \bar{q}_{a}(\alpha-1)$, que é a diferença entre 0 que se pagaria se a quantidade total de água consumida fosse paga pelo preço marginal, $q_{a} k$, e o valor pago por este sistema de cobrança. Este conceito de 
subsídio ou imposto (no caso de estrutura tarifária decrescente) denominado diferença ${ }^{22}$, e entra como variável explicativa nos modelos de demanda por água, pois existe uma variação real na renda disponível para o consumidor.

Na maximização da função utilidade, $U\left(q_{a}, q_{b}\right)$, sujeito a renda $y$ e a estrutura tarifária - ETB, Andrade et al. (1996) demostram que para uma função utilidade qualquer, a elasticidade-renda é ponderada pela participação da renda no gasto que excede ao valor mínimo. Assim, quando a despesa com água é uma parcela muito pequena da renda, o modelo tradicional é válido.

Os mesmos autores, usando uma função utilidade do tipo Cobb-Douglas, $U\left(q_{a}, q_{b}\right)=\beta \log q_{b}+\rho \log q_{a}$, onde $\beta>0, \quad \rho>0, \quad e \quad \beta+\rho=1$, encontram a demanda por água é dada por:

$$
q_{a}=\frac{Y+(\alpha k-k) \bar{q}_{a}}{\alpha k} \frac{\rho}{\rho+\beta}=\rho \frac{\left[Y+(\alpha k-k) \bar{q}_{a}\right]}{\alpha k}
$$

Pode-se ver que o preço marginal é a variável relevante na decisão do consumidor; a expressão $(\alpha k-k) \bar{q}_{a}$ é a transferência da renda referente ao consumo no primeiro bloco; e a última e maior restrição para o uso deste modelo é que o coeficiente da variável renda é igual em valor e sinal contrário ao da variável diferença ${ }^{23}$. O efeito-preço e a elasticidade-preço são ambos negativos e crescente em $\alpha$. O efeito-renda e a elasticidade-renda são ambos positivos, sendo que o primeiro independe da renda, mas a elasticidade cresce com o nível de renda. Além disso, as elasticidades preço e renda tendem para -1 e +1 , respectivamente para níveis de renda mais elevada.

\footnotetext{
${ }^{22}$ Proposto por Nordin e Taylor, sendo utilizado em diversos trabalhos.

${ }^{23}$ Esta restrição também é válida para o modelo LES, segundo os autores.
} 


\section{REVISÃO DE LITERATURA}

Apesar da grande diferença entre os sistemas de abastecimento de água, Zarnikau (1994) encontrou características comuns entre eles. Os sistemas urbanos de abastecimento de água são, em geral, organizados na forma de monopólio público ou privado, sujeito à regulação do estado.

Os estudos sobre estimação da curva de demanda residencial de água podem ser classificados de diferentes formas. Os primeiros trabalhos testaram a hipótese da inelasticidade-preço ${ }^{24}$ da demanda de água residencial. Nessa linha estão os trabalhos publicados até a década de setenta, onde a preocupação era determinar quais variáveis eram relevantes para explicar sua demanda. À partir dos trabalhos de Taylor (1975) e Nordin (1976), devido a estrutura da tarifa ser em blocos, surge outra questão bastante discutida na literatura, ou seja, sobre qual preço o consumidor reage, se é o preço médio ou marginal. Além da percepção do preço pelo consumidor, existe o problema econométrico da simultaneidade na determinação do preço pago e da quantidade consumida.

Outra questão bastante interessante está relacionada com o nível de desagregação dos dados. Isto é, se o apropriado seria utilizar os valores médios para o município ou por residência. Além disso, os dados podem ser de

\footnotetext{
${ }^{24}$ Como acreditavam que fossem quase todos os serviços de utilidade pública, não respondendo a variação de preço.
} 
série temporal, cross-section, ou uma combinação de ambos. Podem ser municipal, regional ou nacional.

Parte do debate sobre demanda de água resulta do sistema de sua cobrança, normalmente conhecido como estrutura tarifária em blocos. Esse sistema determina preços diferenciados de acordo com as faixa de consumo. Para o Brasil, no caso de água, as tarifas são crescentes. Além disso, no primeiro bloco de consumo (até $10 \mathrm{~m}^{3}$ ) todos pagam pelo consumo máximo do bloco, apresentando uma conta única, mesmo para os que consomem menos de $10 \mathrm{~m}^{3}$ (ver gráfico 1). Esse sistema, além de não ser consistente com a teoria do consumidor, pois na primeira faixa de consumo, qualquer consumo inferior ao máximo não seria racional e impõe um custo adicional para consumo na faixa de baixa renda e estimula o aumento do consumo.

Dado que o valor cobrado varia por faixa de consumo, resta a dúvida de qual preço o consumidor leva em consideração, se é o preço médio ou o preço marginal. Gottlied (1963), usa o preço médio na determinação da curva de demanda de água. Howe \& Linawever (1967) discutem que se o preço não tem efeito significativo sobre a demanda, decisões sobre tarifas teriam duas finalidades: a) cobrir os custos do sistema de abastecimento de água; e b) ter algum poder de equilíbrio entre os consumidores. Os autores usaram o preço marginal, fazendo algumas pressuposições sobre o comportamento da curva de demanda. A primeira é que quanto maior a proporção da renda gasta com o bem, maior será o efeito renda devido a uma mudança no preço e maior será a variação na quantidade demandada. A segunda é que quanto maior o número de substitutos próximos existir, maior será o efeito substituição de uma mudança no preço e maior será a mudança na quantidade demandada do bem. Nos EUA, o gasto com o consumo de água representa uma pequena parcela dos gastos de uma família, portanto, o efeito de uma variação na renda traria pequena alteração na quantidade demandada. Como não existe um substituto 
próximo para água, principalmente no curto prazo, aumentos de preço, trariam pequena diminuição no consumo de água.

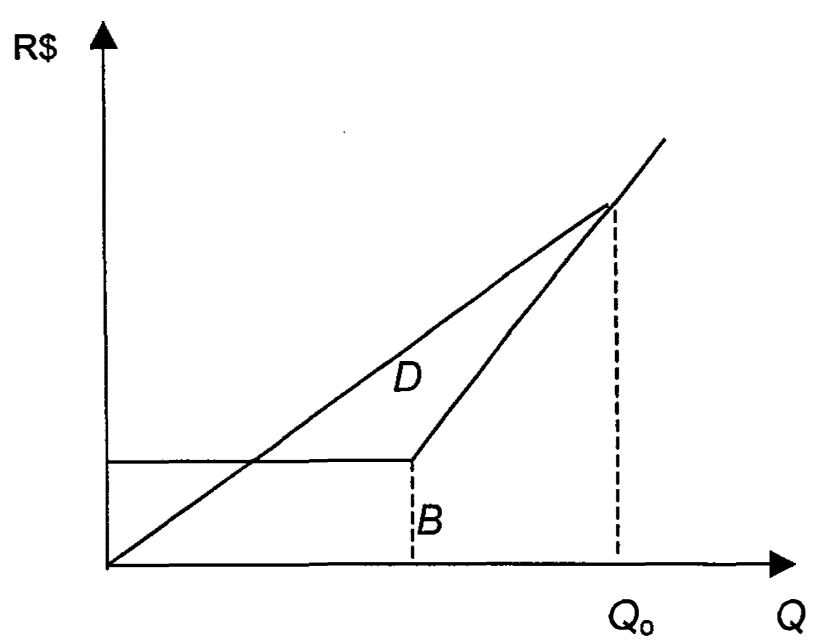

Figura 6. Valor da fatura de água, preço médio, preço marginal e diferença.

Esses autores separaram ainda o consumo da água em interno (in house) e externo (sprinkling) ${ }^{25}$. O uso interno foi definido como consumo nos meses de inverno e o uso externo considerado como o consumo no verão menos o consumo no inverno. Essa divisão foi usada em diversos trabalhos realizados em regiões temperadas, onde a presença de inverno rigoroso não permite atividade externa com água nesta estação, como regar jardim ou lavar a garagem. Foi usada uma série cross-section do consumo médio e dos picos de consumo diário e semanal. Os resultados mostram que a demanda de água externa foi elástica, enquanto as demais, isto é, a demanda interna e a demanda nos picos diário e semanal foram relativamente inelásticas em relação ao preço.

${ }^{25}$ Além de separar áreas de apartamento, fossas sépticas e outros usos. 
Separando o consumo de água em interno e externo, Morgam (1973) estima um modelo para Santa Barbara, Califórnia, usando dados por residência obtidos através de amostragem. As variáveis relevantes para o modelo encontrado foram valor da propriedade e número de residentes e encontrou economia de escala no uso da água para tamanho da residência. $O$ autor criticou o trabalho de Howe \& Linaweaver (1967) devido ao uso de dados médios para estimar o consumo residencial, pois diminui a variância das estimativas. Dado que o modelo é feito num corte no tempo esses autores não usaram variável preço.

Esta discussão acirrou-se depois que Taylor (1975) publicou o clássico artigo sobre demanda por eletricidade nos Estados Unidos, onde constatou que quase todos os artigos publicados sobre demanda, usavam o preço médio como variável explicativa, o que contradiz a teoria econômica ${ }^{26}$. Porém, além da a inclusão do preço marginal nos modelos, esse autor defende a utilização de uma outra variável, preço médio ou despesa total, para captar o efeito da mudança na renda, causada pela alteração de preço entre as faixa de consumo.

Wong (1972) usou duas séries de dados para Chicago. A primeira é uma série temporal (1951-61) com dados de Chicago e região metropolitana (outside communities). A segunda é um corte no tempo (cross-section), para 103 cidades estratificadas segundo tamanho da população. $\mathrm{Na}$ análise da região metropolitana, a demanda de água per capita foi função do preço médio anual, da renda média da residência e da média de temperatura nos meses de verão. Para a série seccional, a temperatura não foi incluída na análise, pois dentro de uma mesma região a variação não foi significativa. A regressão na forma logarítmica foi estimada através do método de Mínimos Quadrados

${ }^{26}$ Segundo a teoria neoclássica, no equilibrio, o consumidor iguala os benefícios marginais ao custo marginal, sendo este igual ao preço marginal, e não o preço médio. 
Ordinários $\left(O L S^{27}\right)$. Os resultados indicaram que para a região metropolitana, tanto temperatura, quanto renda foram mais importantes que o preço para explicar o consumo de água ${ }^{28}$. $\mathrm{O}$ coeficiente do preço tem o sinal previsto pela teoria, isto é, negativo, porém não significativo. No corte no tempo (crossseccional), preço e renda são significativos nas cidades maiores. Nas menores, somente o preço tem influência na demanda de água.

Também usando dados com corte no tempo, Young (1973) estimou, por OLS, a elasticidade preço de demanda por água para Tucson, Arizona. Usou a venda per capita no varejo como proxy da variável renda. Porém, os sinais das variáveis no modelo estimado foram contrários aos que a teoria prevê, talvez por problemas existentes nos dados. O preço médio foi usado como variável explicativa do modelo, sem entrar na discussão atual sobre que tipo de preço deveria ser usado.

Foster \& Beattie (1979) em outra linha de análise, usaram OLS para estimarem o modelo:

$$
Q=f(P, Y, R, N) \text { ou } \quad Q=\beta k e^{\beta \rho P} Y^{\beta Y} R^{\beta r} N^{\beta n} \varepsilon
$$

onde:

$Q$ é a quantidade de água demandada por residência $\mathrm{em}^{3}$;

$P$ é o preço médio anual da água por $\mathrm{m}^{3}$;

$Y$ é renda média das famílias;

$R$ é a precipitação durante a estação; $\mathrm{e}$

\footnotetext{
${ }^{27}$ Usando a sigla em inglês, como é mais conhecida, Ordinary Least Squares - OLS.

${ }^{28}$ Parte da razão da insignificância do preço como variável explicativa é a baixa tarifa, que não estimula a economia no consumo.
} 
$N$ é o número médio de residentes por metro quadrado.

A diferença de consumo entre regiões, é captada pela presença de variáveis dummies. Foram usados dados cross-section de 218 cidades em um modelo geral de demanda residencial de água onde os determinantes do consumo são diferenças regionais e tamanho das cidades. Os trabalhos que usam dados agregados de um determinado município não captam muitos fatores que influenciam a demanda de água, pois são constantes na amostra. Segundo esses autores, os antigos modelos assumiam que as características das indústrias regionais e o tamanho da população determinariam a quantidade demandada de água e que a demanda futura dependia apenas do crescimento populacional e tipo de desenvolvimento urbano. A hipótese de que o consumo não varia entre regiões foi rejeitada e que as variáveis importantes para explicar a demanda foram: preço, renda, precipitação e número de pessoas por metro.

Danielson (1979) estima uma função de demanda residencial para Raleigh, Carolina do Norte, usando como variáveis independentes a temperatura, a precipitação, o valor da residência, o preço da água e o tamanho da residência. $O$ estudo usa um modelo econométrico proposto por Kmenta para uma série temporal com diferentes municípios (pooled cross-section e time-series), obtida por amostragem nas residências. Apesar da estrutura tarifária ser em blocos, o autor justifica o uso do preço no primeiro bloco pela maior concentração de dados nessa classe. O consumo foi dividido em interno, externo e total, como definido por Howe \& Linawever (1967). Os resultados não diferem dos trabalhos anteriores, onde a elasticidade-preço do uso externo é superior ao interno e a maior parte da variação na demanda foi explicada pelo tamanho da residência.

Nordin (1976) concorda com Taylor de trabalhar com $P M g$, só que defende a inclusão de mais uma variável chamada diferença, $d^{*}$, que é a diferença entre a conta paga e o produto do preço marginal pela quantidade 
consumida (Figura 1). Desta forma, é possível captar o efeito-renda proveniente da mudança da faixa de consumo.

Polzin (1984) critica a abordagem proposta por Nordin, pois perde-se um grau de liberdade, piorando a especificação do modelo. Isso é relevante quando a série é pequena ou com muitos parâmetros para estimar.

Billings \& Agthe (1980) justificaram o uso do preço médio somente quando a tarifa não é em blocos. Quando os blocos apresentam preços crescentes, o impacto pode ser dividido em efeito renda e substituição. Porém , no caso da água o efeito substituição é reduzido.

O modelo utiliza as variáveis preço marginal (PMa); diferença $(D)$; renda $(Y)$; e clima (diferença entre a evapotranspiração e a quantidade de chuva) com modelos na forma linear e logarítmica, para a cidade de Tucson, Arizona. Os resultados obtidos apresentam elasticidade-preço negativa e significativa nos dois modelos. Porém, a variável diferença apresenta elasticidade negativa, mas não com o valor previsto pela teoria, que prevê o mesmo valor e sinal contrário ao encontrado para a elasticidade-preço.

Griffin e Martin (1981) criticam o trabalho de Billings e Agthe (1980) por acreditar que pela maneira como foi calculada a função de demanda, vai existir viés nas estimativas. Os modelos propostos por Taylor e Nordin foram resultados de trabalhos teóricos sobre o comportamento do consumidor, não envolvendo estudos empíricos. As análises de Nordin e Taylor mostram que a quantidade de água consumida por um consumidor, face a uma tarifa em múltiplas partes, depende do preço marginal encontrado pelo consumidor na faixa de seu consumo e do imposto ou subsídio resultante do preço intramarginal. Mudanças na parte intramarginal (diferença) e na renda têm exatamente o mesmo efeito na quantidade de água consumida. Como o preço pago pelo consumidor varia com o consumo de acordo com a regra tarifária, o 
uso de OLS pode resultar em estimativas viesadas. Desta forma o resultado de uma análise de regressão não será uma curva de demanda, relacionando preço e quantidade, e sim o resultado da regra tarifária (rate schedule) e a função de demanda atual. As variáveis preço e diferença observadas não correspondem aos pontos onde a curva de demanda corta a regra tarifária. Dessa diferença aparece o erro da regressão. $O$ viés é correlacionado positivamente com a variância do erro. $\mathrm{E}$, quando a última cresce, cresce também o número de observações de quantidade consumida que mudam indevidamente de faixa de preço. Isso acarretará uma mudança na direção da regra tarifária e dos coeficientes, superestimando o efeito da variável diferença e diminuindo o da variável preço marginal.

Billings e Agthe (1981) em réplica às criticas feitas por Griffin e Martin (1980) sobre o uso de OLS para estimar a regressão de demanda de água, justificam que foram 2 os casos onde houve mudança de bloco e que retirando-os da amostra e recalculando o modelo, a elasticidade preço da demanda é maior e a elasticidade da variável diferença é menor neste novo modelo linear. Contudo, devido a alta significância obtidas, sugerem que os resultados sejam usados para prever os efeitos de uma variação de preços sobre o consumo.

Griffin, Martin e Wade (1981) criticam o trabalho realizado por Foster e Beattie (1979), que usaram preço médio, renda e precipitação para explicar a variação do consumo de água em duzentas cidades americanas. A critica é baseada no fato do preço médio variar inversamente com o consumo e do preço marginal não ter alta correlação com o preço médio. Assim, os três autores concluem que a relação encontrada por Foster e Beattie é uma função de oferta, refletindo a regra tarifária, pois onde o preço médio é alto, o consumo é baixo devido à tarifa decrescente usada na amostra. A sugestão é para os dois autores refazerem seus cálculos levando em consideração a função tarifa. 
Na mesma revista Foster e Beattie, rebatendo as críticas defendem o uso do preço médio para estimar o consumo residencial anual de água, como feito em trabalho anterior, com o uso de dados agregados e que o problema de identificação da regra tarifária não é sério. Devido à complicada estrutura da tarifa, alegam a má informação do consumidor e sendo o preço médio determinado ex-post, a dependência negativa entre preço e quantidade é mero cálculo.

Foster e Beattie $\left(1981^{\mathrm{a}}\right)$, citando ainda as questões levantadas por Griffin, Martin e Wade, discordam da perfeita informação contida nos trabalhos de Taylor e Nordin. Parte desse problema é devido à pequena participação da conta da água nas despesas domésticas e parte devido a estrutura tarifária com vários preços. Esses autores, usando os mesmos dados de seu artigo anterior publicado em 1979 calculam o modelo proposto por Nordin, com o procedimento sugerido por Griffin, Martin e Wade (1981). Com exceção da variável diferença, que teve sinal inverso ao esperado e valor diferente do coeficiente da renda, os valores estão conforme a teoria, com significância a $1 \%$ e $\mathrm{R}^{2}$ explicando $50 \%$ da regressão. Porém, os resultados do trabalho anterior, de Foster e Beattie (1979), foram superiores nos dois critérios analisados, $R^{2} \mathrm{e}$ teste F. No outro teste, se existe diferença significativa nos parâmetros dos dois modelos, um com preço médio e outro com preço marginal, não foi encontrada diferença em nivel de $10 \%$. A conclusão do trabalho é que usando dados agregados, o preço médio é um bom indicador de preço.

Terza \& Wellch (1982) fizeram um trabalho teórico mostrando inconsistência no uso de OLS na estimação da demanda de energia elétrica e água sob estrutura tarifária em blocos. Nesses casos, o consumo e o preço estão interligados pela regra tarifária, causando viés nas estimativas dos parâmetros. A solução apontada para resolver esse problema foi a estimação 
em dois estágios ${ }^{29}$, usando o método probito, no primeiro estágio. A variável dependente tem valor 0 ou 1 , de acordo com o bloco que o consumidor se encontra. O estimador resultante é viesado, mas consistente. Esses autores recomendaram também o uso de dados por residência, o que na prática nem sempre é possivel de obter .

O uso de OLS para estimar o modelo proposto por Taylor e modificado por Nordin foi criticado por muitos autores, que indicam viés nas estimativas dos parâmetros (Griffin e Martin, 1981; Terza e Wellch 1982 ; Griffin, Martin e Wade, 1981). Foster e Beattie (1981ª) discutem se o consumidor conhece a estrutura tarifária de cobrança em blocos, onde cada faixa de consumo apresenta diferente preço marginal. Se os consumidores não conhecerem a estrutura tarifária, talvez o preço médio fosse o mais correto. Para tentar provar esta afirmação, refazem a curva de demanda de água, com os mesmos dados do trabalho anterior e usando o modelo de Nordin. Os resultados usando preço médio são superiores ao do modelo de Nordin, apresentando tanto $R^{2}$ como $\circ$ teste $F$ superior ao modelo usando preço marginal.

Billings (1982) usa a variável diferença e o preço marginal para estimar a equação de demanda através do uso de variável instrumental. Estimou o dispêndio total ${ }^{30}$ mesmo o uso de variável instrumental não elimina o problema causado pela simultaneidade entre preço e quantidade:

$$
D T=D+P M g Q+u
$$

Dado que o consumidor encontra no sistema de abastecimento de água uma tarifa em blocos, em vez de preço fixo, a quantidade consumida de água depende de um sistema de preço e não de um preço único (Griffin \&

\footnotetext{
${ }^{29} \mathrm{O}$ método usado foi similar as usado por Heckman (1978).

${ }^{30}$ Conta paga pelos consumidores.
} 
Martin, 1981). A análise feita por Taylor e Nordin mostra que a quantidade de água demandada, sob um sistema de tarifas de múltiplas parte, depende não só do preço marginal, mas também do subsídio ou taxação implícitos na conta, captada pela variável diferença. Porém, a análise de regressão ${ }^{31}$ feita por Billings \& Agthe, segundo Griffin \& Martin, apresentou estimativas viesadas por trabalhar com preço marginal e diferença como variáveis explanatórias. $O$ viés aparece porque existe correlação entre o consumo observado, o preço observado e a diferença observada.

Recomendando cautela na identificação do preço quando é dependente da quantidade comprada, Jones e Morris (1984) advertem que um erro na quantidade observada vendida introduz um erro correspondente no preço, resultando em correlação entre uma variável explicativa e o termo de erro da regressão. Deste modo, o método de estimação por mínimos quadrados ordinários (OLS) não é consistente e pode ser viesado.

Jones e Morris usaram três formas funcionais ${ }^{32}$ para estimar a demanda de água residencial para a região metropolitana de Denver, Colorado, baseados numa amostra de 889 famílias no ano de 1976. O modelo adotado de variável instrumental (Mc Fadden et al., 1977) para estimar uma uma nova variável relacionada com preço, mas ortogonal com o distúrbio da regressão. Outros autores desenvolvem três variáveis instrumentais de preço: médio, marginal e intramarginal (ou diferença) através da relação estatística entre preço observado ou de compra (purchases) e a informação de preço exata.

A conclusão foi que a estimação através de variável instrumental não produz resultados diferentes do simples uso de OLS. Em particular, a utilização do preço médio traz resultados confiáveis quando os dados são deficientes ou

${ }^{31}$ O modelo proposto foi que a quantidade de água dependia do $P M g, d$, renda da casa e tempo.

32 Linear, multiplicativa e semilog. 
não se tem uma especificação exata da demanda. Os resultados do trabalho devem ser olhados com certa cautela, dado o baixo $R^{2}$ encontrado nos modelos $^{33}$.

Através de dados de consumo por atividade, obtidos um levantamento na Inglaterra, Archibald (1983) montou um modelo de previsão de consumo doméstico per capita, $O$ estudo calcula os fatores que afetam cada tipo de consumo, desde banho, máquina de lavar roupa e louças, lavar carros, molhar jardim, entre outros.

Henson (1984) discute que nos modelos usando OLS para calcular o modelo proposto por Nordin, os valores encontrados para os coeficientes são inconsistentes. Com tarifa sob estrutura de blocos crescentes, o coeficiente do preço marginal tende a ser viesado para zero e o coeficiente da variável diferença tende a ser viesado para valores distantes de zero.

Nieswiadomy \& Molina (1989) usaram dados de 101 residências na cidade de Denton - Texas, para estimar a demanda residencial de água. Os dados são provenientes de uma amostra aleatória, para o período de 1976-85, com uma particularidade: os dados apresentaram uma estrutura tarifária em blocos decrescente para o período 1976-80 e crescente o restante do período. A função de demanda seguiu a forma sugerida por Nordin, onde o coeficiente da variável diferença deve ter igual magnitude e sinal contrário ao coeficiente da variável renda. As seguintes variáveis também foram inclusas: tamanho do terreno, renda, tamanho da casa e clima como variáveis explicativas. Através do teste da Hausman o estudo compara métodos de estimação: variável instrumental e mínimo quadrado em dois estágios. O uso do método de $\mathrm{VI}$ melhorou as estimativas, pois a linearização do sistema de cobrança (obtido no primeiro estágio) elimina o viés da estimativa. Os resultados mostraram que não

\footnotetext{
${ }^{33}$ Entre 0,23 a 0,28.
} 
houve variação significativa entre os resultados obtidos por VI e 2SLS. Nos dois modelos as variáveis explicativas tiveram os sinais esperados e foram significativos. A variável, porém, não correspondeu à hipótese proposta por Nordin, que o coeficiente da variável diferença tem a mesma magnitude e sinal contrário ao da variável renda.

Trabalhando com dados levantados por amostragem, em 30 cidades do Texas, para um período de três anos, Griffin e Chang (1990) determinaram que o modelo usando preço médio superior ao preço marginal. $O$ resultado do modelo usando dados em painel foi inferior ao do OLS. Mas, a principal contribuição do trabalho foi relatar a importância do estudo de demanda sazonal para a água e confirmar a existência de variação sazonal na elasticidade preço de demanda.

Hansen (1996), usando uma série temporal para cidade de Copenhagen e sua área metropolitana, estimou uma função de demanda para água residencial. Um modelo de função de produção domiciliar para consumo de água, energia e um agregado de outros bens. O trabalho utiliza preço marginal, pois a estrutura tarifária é de preço constante para qualquer consumo. A elasticidade preço para água, foi estimada em -0,1, e a elasticidade-cruzada para o preço da energia de $-0,2$, maior que para o seu próprio preço.

Para determinar os fatores que afetam as estimativas de elasticidade preço em estudos de demanda de água nos Estados Unidos, Esperey et al. (1997) usaram 124 estimativas de 24 artigos publicados entre 1967 a 1993, em uma meta-analysis. Os autores concluem que os fatores que mais afetam a elasticidade são: evapotranspiração, estrutura de preços, chuva e estação do ano. Um outro resultado ineressane foi que existe uma diferença significativa entre elasticidade de curto prazo e longo prazo.

Um dos primeiros trabalho realizado no Brasil sobre demanda de água éo de Andrade et al. (1996) com dados obtidos através de amostragem 
em 27 municípios do Paraná, onde foram levantadas 5.417 residências. As variáveis explicativas do modelo são: preço marginal, diferença intramarginal, renda familiar e o número de pessoas residentes. Devido ao valor da variável diferença ser negativo no primeiro bloco ${ }^{34}$, não foi possivel usar a especificação na forma logarítmica, sendo testada somente a forma linear. Para corrigir o problema causado pela simultaneidade entre consumo e preço, foram usados os métodos de Mínimos Quadrados em Dois Estágios e o de Variável Instrumental. O modelo foi calculado para amostra geral e para sub-amostras de acordo com as classes de renda ${ }^{35}$. A elasticidade-preço em todas as amostras foi, em módulo, menor que um, e maior na camada de baixa renda. As variáveis renda e número de pessoas residentes apresentam elasticidades muito próximas de zero, significando que essas variáveis têm pouca influência no consumo de água para os dados usados neste trabalho. $O$ coeficiente da variável diferença é negativo e, em módulo, muitas vezes superior ao da variável renda, não comprovando a teoria de sinais contrários e valores iguais para essas variáveis. Esse resultado está de acordo com vários outros autores (Billing e Agthe (1980), Mattos (1998); Foster e Beattie (1981); Jones e Morris (1989), entre outros. Ainda segundo os autores, a principal crítica que pode ser feita na análise é que não houve variação de preço na amostra e os preços diferiram somente entre blocos.

Mattos (1998) estima a equação de demanda residencial de água para o município de Piracicaba, usando o modelo proposto por Nordin. Apesar da limitação de dados existente, ela utiliza os diferentes métodos de estimação: Mínimos Quadrados Ordinário; Variável Instrumental e Mínimos Quadrados em Dois Estágios. Os métodos de variáveis instrumentais foram superiores ao

\footnotetext{
${ }^{34}$ Devido ao valor mínimo da conta para o consumo até $10 \mathrm{~m}^{3}$, podendo ser interpretado esse resultado como um imposto cobrado ao consumidor.

${ }^{35}$ Renda até 2 salários mínimos; de 2 à 10 salários mínimos; e mais de 10 salários mínimos.
} 
mínimos quadrados ordinário, confirmado pelo teste de Hausman ${ }^{36}$. As únicas variáveis significativas foram PMa e $D$. Os resultados encontrados para o Brasil são semelhantes aos demais, isto é, não existe igualdade dos valores absolutos e sinais contrários nos coeficientes estimados para diferença e renda.

Para a região de Sabaé, estado da Bahia, Carrera-Feranadez e Menezes (2000) estudaram os determinantes da disponibilidade a pagar pelo serviço de abastecimento de água e a demanda de água potável pelo método de valoração contingencial. Constatam que a disposição a pagar dos consumidores do serviço de água é inferior ao necessário para melhorar o abastecimento e atender a toda a população. $O$ estudo constata ainda que deve haver uma grande participação do poder público para melhoria e ampliação dos sistemas de abastecimento público de água potável, pois os consumidores não estão dispostos a aumentarem os preços da fatura para poder cobrir os investimentos necessários.

Nazen (1996) sugere o uso de modelo de séries temporais para estudo de demanda de água. Isso devido a demanda urbana por água ser dependente de inúmeros fatores incontroláveis relativo ao clima, tornando a demanda de curto-prazo bastante volátil. Outro fator é a sazonalidade do consumo nos meses de verão. Sugere que modelos de séries temporal podem trazer bons resultados para o planejamento para o uso da água.

\section{1- Teste entre Modelos}

Opaluch (1982) defende o uso do teste empírico para ver a qual preço o consumidor responde usando o modelo:

\footnotetext{
${ }^{36}$ Maiores detalhes a seguir, no item dos testes de hipótese.
} 
$Q=B_{0}+B_{1} P_{x}+B_{2} P_{2}+B_{3}\left(\frac{\left(P_{1}-P_{2}\right) Q_{1}}{Q}\right)+B_{4}\left[Y-\left(P_{1}-P_{2}\right) Q_{1}\right]$

onde:

$Q$ é o consumo total de água;

$P_{x}$ é o preço dos demais bens;

$P_{2}$ é o preço da água no segundo bloco ou preço marginal;

$P_{1}$ é o preço da água no primeiro bloco;

$Q_{1}$ é a quantidade da água sujeito a $P_{1}$;

$Y$ é a renda total do consumidor;

Se o consumidor é bem informado, reagindo à estrutura de tarifa em blocos, $B_{3}=0$, o modelo retorna à forma do modelo de demanda de preços em blocos de Nordin. Se $B_{2}=B_{3}$ então o consumidor responde ao preço médio.

Porém, o teste de Opaluch não permite que o consumidor reaja a ambos os preços, médio e marginal. Shin (1985) apresentou um modelo que inclui um parâmetro de percepção de preços a ser estimado explicitamente, pois o consumidor provavelmente não conhece a natureza da estrutura dos preços em blocos, ou não a percebe até receber a conta (fatura).

Chicoine \& Ramamurthy (1986) discutiram o problema de qual preço seria relevante para estimar a curva de demanda quando a estrutura tarifária é em blocos decrescentes, sugerindo o teste de Opaluch para resolver o problema. Os dados são oriundos de uma amostra estratificada para 59 sub- 
distritos de Illinois, com dados mensais para o ano de 1982. O modelo estimado foi:

$Q_{i, t}=B_{0}+\sum_{t=1}^{11} B_{1 t} M_{t}+B_{2} P M g_{i t}+B_{3} D_{i t}+B_{4} Y_{i t}+B_{5} N_{i}+B_{6} N b_{i}+e_{i t}$

onde:

$Q_{i t}$ é o consumo de água pela residência $i$ no mês $t$;

$M_{t}$ é a variável binária para o mês;

$P M g_{i t}$ é o preço marginal pago pela residência $i$ no mês $t$;

$D_{i t}$ é a variável diferença da residência $i$ no mês $t$;

$Y_{i t}$ é a variável de renda da residência $i$ no mês $t$;

$N_{i}$ é o número de habitantes da residência $i$;

$N b_{i}$ é o número de banheiros da residência $i ; \mathrm{e}$

$e_{i t}$ é o termo de erro com distribuição iid $N\left(0, \sigma^{2}\right)$.

O resultado mostrou que o consumidor leva em conta o preço médio para responder ao consumo de água.

Nieswiadomy \& Molina (1991) usaram o modelo de Shin para estimar um modelo de demanda de água para uma série mensal, com observações individualizadas de residência. Os autores mencionam que uma outra razão que dificulta a percepção de qual preço o consumidor reage é que a conta de esgoto 
vem cobrada na mesma fatura. Usando os mesmos dados do estudo anterior, eles estimaram o modelo proposto por Shin, onde a variável preço percebido $p^{*}$ é função do preço marginal, preço médio e $k$, (um parâmetro de percepção do preço), como segue:

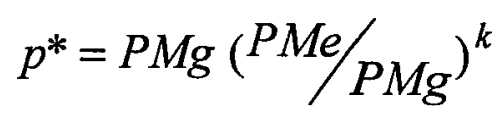

Se o consumidor somente responde ao preço médio, então $k=0$, se reage ao preço marginal, $k=1$. Se o preço percebido está entre o preço médio e marginal, então $0<k<1$. 0 argumento dado pelos autores para o uso de $p^{*}$ é que este proporciona um ajustamento dinâmico, que é necessário pois 0 consumidor não muda seu estoque de capital $e$ seus hábitos instantaneamente. Eles estimaram o modelo:

$$
\begin{aligned}
\ln Q_{i, t}= & \beta_{0}+\beta_{1} \ln Q_{i, t-1}+\beta_{2} \ln Y+\beta_{3} \ln P M g_{i, t}+ \\
& \beta_{3} \ln \left(P M e_{i, t-1} / P M g_{i, t}\right)+\beta_{4} \ln A I+\beta_{5} \ln T
\end{aligned}
$$

onde $A I$ é a área irrigada e $T$ a variável relacionada ao tempo. $\mathrm{O}$ resultado do teste de Hausman para endogeneidade entre $P M g$ e $P M e / P M g$ foi significativo a $1 \%$. Concluíram o trabalho mostrando que o consumo residencial de água responde ao $P M g$ quando a estrutura tarifária é em blocos crescentes e ao PMe quando é em blocos decrescentes.

Hausman (1978) criou um teste para detectar a presença de simultaneidade nos dados sobre preço e quantidade. Testa a hipótese de nulidade, que significa que os preços são variáveis exógenas, contra a hipótese alternativa, que é que os preços são exógenos. Utiliza os resultados obtidos por OLS para testar se estes são consistentes e assintoticamente eficientes sob a 
hipótese da nulidade ${ }^{37}$. Os estimadores da VI serão consistentes sob a hipóteses de nulidade e da alternativa, mas não será assintoticamente eficiente sob a hipótese de nulidade. Monta uma estatística $m$, que apresenta distribuição $\chi^{2}$, assim definida:

$$
m=b^{\prime}\left(V_{* *}-V_{O L S}\right)^{-1} b
$$

onde $b=b_{* *}-b_{\text {oLs }}$ é o vetor de coeficientes da regressão; $V$ representa a matriz de variância-covariância dos coeficientes; onde ** representa o método alternativo e OLS, mínimos quadrados ordinário.

\section{2- Problemas com os dados}

No Brasil, passamos pelos mesmos problemas que Wong (1972) comentava, na obtenção de dados para estimar a demanda residencial de água, pois:

- Os dados sobre consumo residencial de água de cada unidade não é encontrado, a não ser em amostras isoladas, para fins específicos (Andrade et al., 1996);

- Os dados sobre renda familiar individual são de difícil acesso. Por isso, normalmente são utilizadas variáveis proxy tais como: renda média do censo populacional, renda média familiar retirada de pesquisa de mercado ou de vendas; ou uma proxy para renda familiar, como tamanho do imóvel, ou número de utensílios domésticos. No Brasil, um dado muito usado como proxy para a variável renda é o Valor Adicionado; e,

- Normalmente não se dispõe de séries longas e/ou em diferentes localidades para os estudos.

\footnotetext{
${ }^{37}$ Se a hipótese da nulidade for confirmada, os preços seriam exógenos.
} 


\section{METODOLOGIA}

Para explicar o consumo de água no município de Piracicaba, foram selecionadas as seguintes variáveis:

CR Consumo Residencial Total, em $\mathrm{m}^{3}$, fornecido pelo Serviço Municipal de Água e Esgoto de Piracicaba (SEMAE);

CT Consumo Total, em $\mathrm{m}^{3}$, que engloba os consumos residencial, comercial, industrial, construção civil, gratuito, horta e entidade social fornecido pelo SEMAE;

CRM Consumo Residencial Médio, em $\mathrm{m}^{3} /$ residência, obtido pela divisão do consumo residencial total pelo número de ligaçõe residenciais;

$P M e$ Preço Médio, em $\mathrm{R} \$ / \mathrm{m}^{3}$, obtido pela divisão do valor da fatura do CRM pelo consumo;

PMg Preço Marginal, em $\mathrm{R} \$ / \mathrm{m}^{3}$ é o valor da tarifa no CRM;

$n L \quad$ Número de Ligações, e número de residências ligadas na rede de distribuição de água no município;

$T$ Temperatura Média Mensal no município de Piracicaba, obtido no Boletim Meteorológico do Depto. De Física e Meteorologia, ESALQ/USP; $e$

Preci,t Precipitação Mensal, obtido no Boletim Meteorológico do Departamento de Física e Meteorologia, ESALQ/USP, para Piracicaba.

A figura 8 apresenta o gráfico com a série de consumo residencial total (CR) de água e o número de ligações. $O$ consumo é notadamente sazonal, com valores de pico nos meses de verão. Além disso, a série apresenta uma tendência de aumento, crescendo com o número de ligações. 


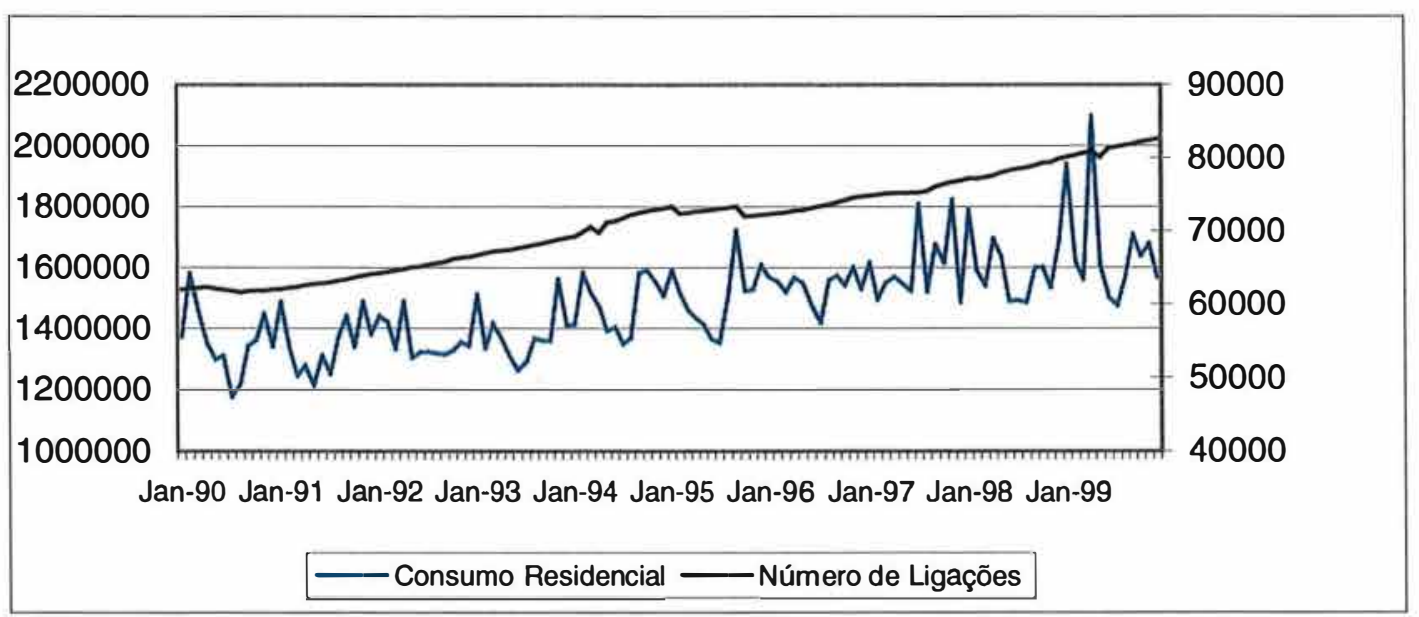

Figura 7: Consumo residencial de água, em $1000 / \mathrm{m}^{3}$, e número de ligações, Piracicaba, janeiro de 1990 a dezembro de 1999.

Fonte: Elaborado pela autora com base em dados fornecidos pelo SEMAE.

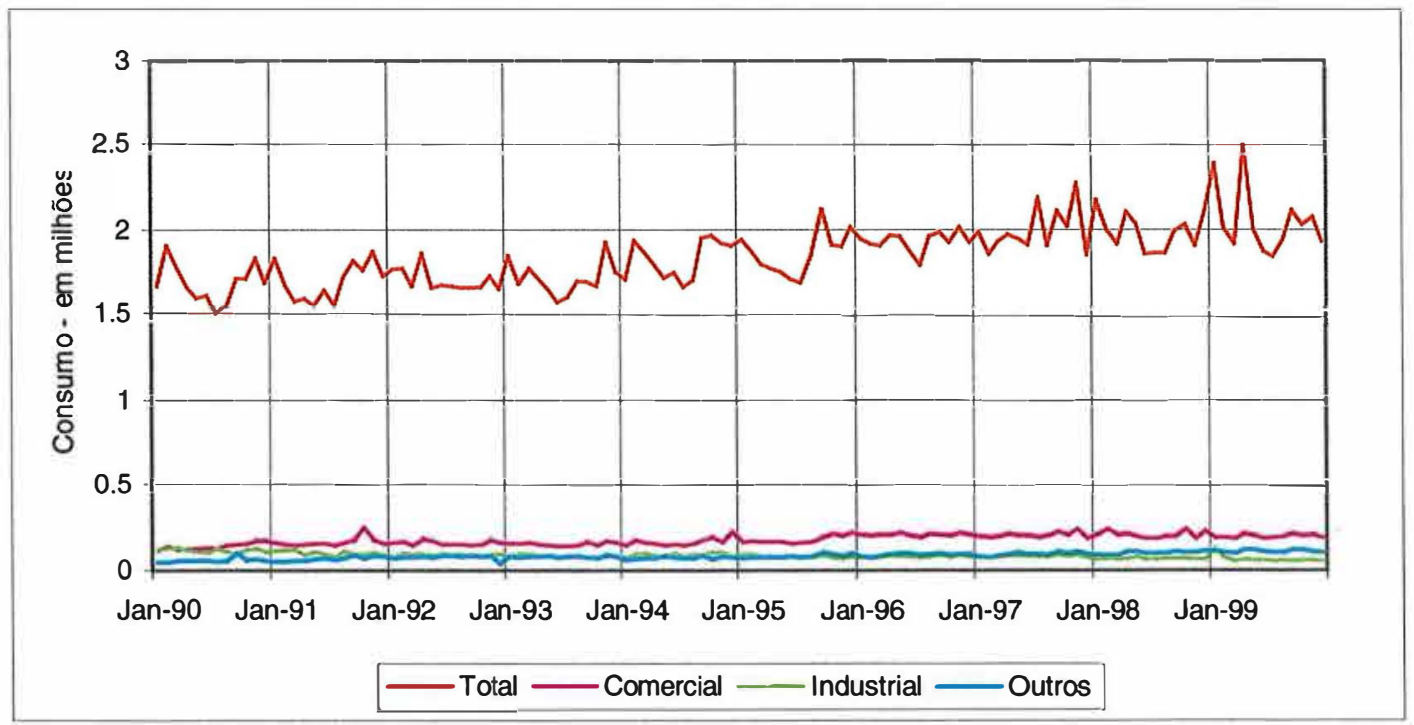

Figura 8: Consumo de água total, comercial, industrial e outros, em $10^{6} \mathrm{~m}^{3}$, Piracicaba, janeiro de 1990 a dezembro de 1999.

Fonte: Elaborado pela autora com base em dados fornecidos pelo SEMAE. 
O consumo total tem forte influência do consumo residencial e apresenta também significativo comportamento sazonal. $O$ mesmo não ocorre nos consumos Comercial, Industrial e Outros (construção civil, gratuito, horta e entidade social), como pode ser visto na Figura 8.

O consumo médio tem uma sazonal como a temperatura ${ }^{38}$, porém com menor amplitude (Figura 9). Outra coisa a ser notada na figura é uma tendência decrescente no consumo médio.

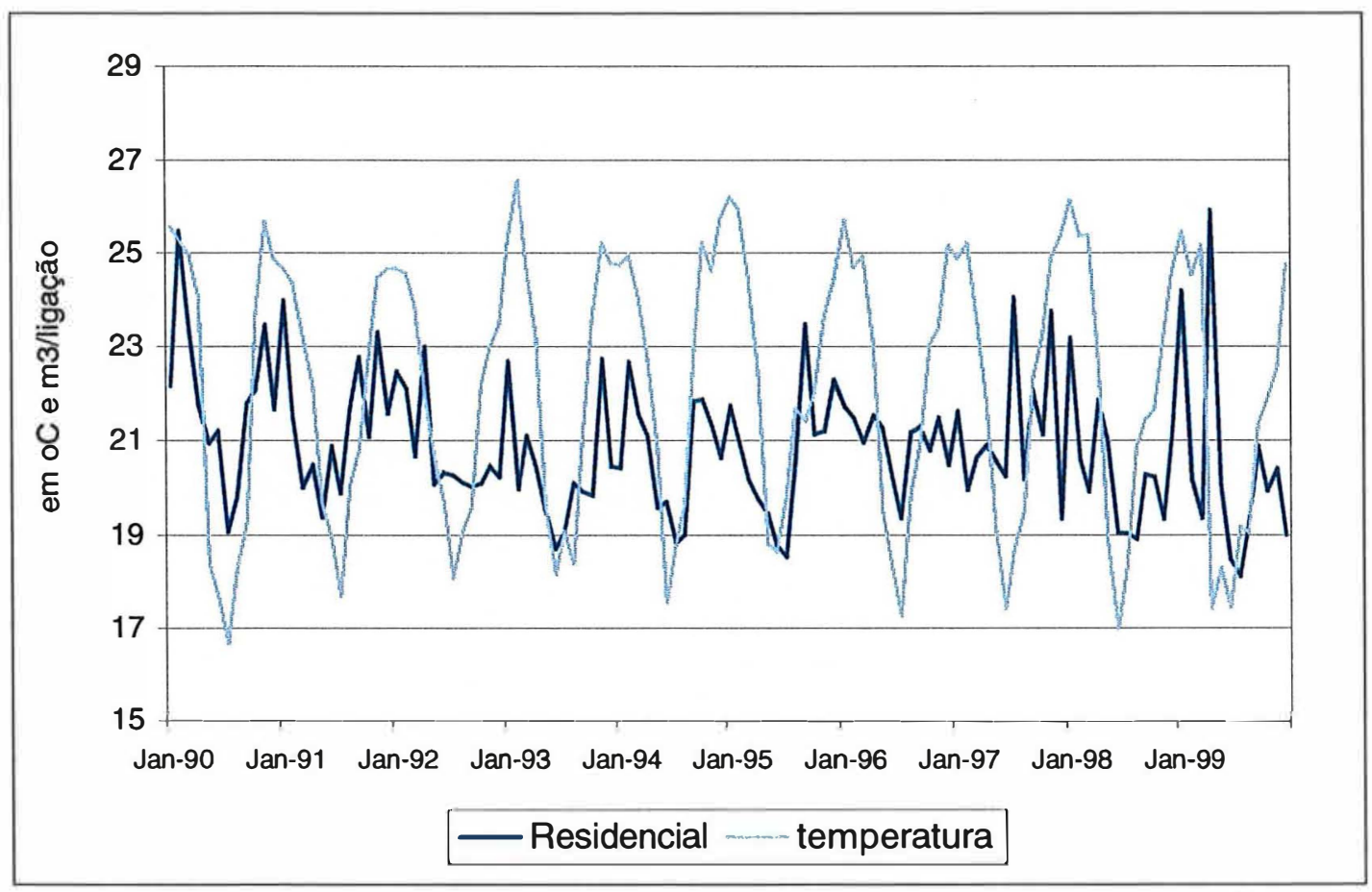

Figura 9: Consumo mensal médio residencial de água, em $\mathrm{m}^{3} /$ ligação, e temperatura média mensal, em ${ }^{\circ} \mathrm{C}$, Piracicaba, janeiro de 1990 a dezembro de 1999.

Fonte: Elaborado pela autora com base em dados fornecidos pelo SEMAE e pela ESALQ/USP.

${ }^{38}$ Porém com menor variância. 


\subsection{Teste de Raiz Unitária}

O teste de raiz unitária é feito para evitar regressão espúria em séries econômicas. Séries econômicas apresentando tendência, apesar de apresentar valores significativos para os testes t e para o coeficiente de regressão $\left(R^{2}\right)$, não apresentam significado econômico (Margarido e Anefalos, 1999). A existência de tendência nos dados gera problemas nos modelos de regressão em função de correlação temporal entre as variáveis. Dessa forma, o uso de estatística clássica nesses casos pode gerar estimativas viesadas, comprometendo a validade dos resultados.

A hipótese básica da estatística clássica é que as variáveis possuem média e variância bem definidas, constantes e sem relação com o tempo (Rao, 1994). Para grande parte das séries macroeconômicas, a aplicação do teste de raiz unitária mostrou que isso não é verdadeiro. As variáveis que possuem média e variância mudando no tempo são conhecidas como não estacionária ou possuidoras da raiz unitária.

A ordem de integração de uma variável representa o número de vezes que a série deve ser diferenciada para se tornar estacionária.

Uma maneira de trabalhar com séries temporais é através do uso do operador de atraso $(B)$, que é definido como:

$$
B^{n} X_{t}=X_{t-n}
$$

onde $n$ corresponde ao período de atraso.

Dessa forma o operador de diferença pode ser representado por:

$$
\nabla^{d} X_{t}=(1-B)^{d} X_{t}
$$

onde $d$ é a ordem da diferença. 
O operador também pode ser usado para retirar a sazonalidade das séries, sendo usado o operador $D$, que representa a diferença sazonal de ordem s, representado por:

$$
\nabla^{D} X_{t}=\left(1-B^{s}\right)^{D} X_{t}
$$

Segundo Margarido (1994) a aplicação de operadores de diferença pode tornar a série estacionária, estabilizando a variância e removendo a tendência das séries originais.

Existem diferentes métodos usados para detectar a presença de raiz unitária. Cada um desses métodos apresenta vantagens e desvantagens. $O$ mais utilizado na literatura econômica é o teste de Dickey-Fuller Aumentado (ADF). Ele permite testar a presença de uma ou mais raízes unitárias no modelo polinomial auto-regressivo $[(\Phi(B)]$ de ordem $p$, pela expressão:

$$
\Phi(B) y_{t}=\alpha+\theta(B) e_{t}
$$

onde, $\alpha$ é a média de $y_{t}$.

O teste ${ }^{39}$ é realizado com os parâmetros da seguinte expressão:

$$
\nabla Y_{t}=\alpha+\beta t+(\rho-1) Y_{t-1}+\sum_{j=1}^{\rho-1} \rho_{j+1} \nabla Y_{t-j}+e_{t}
$$

onde:

$\alpha$ é a constante do modelo;

Y representa a variável dependente;

$\beta t$ é a tendênia determinística;

${ }^{39}$ Retirado de Margarido e Anefalos (1999). 
$\rho_{i}=\sum_{j=1}^{p} \Phi_{j}, i=1, \ldots p$

p é a ordem do modelo ARMA

$e_{t}$ é o ruído branco.

O teste é realizado para o modelo completo, com constante e tendência. A estatística $\tau_{\tau}$ é usada para testar o modelo a hipótese de nulidade que é a presença de raiz unitária. Ainda com o modelo completo, a hipótese nula a ser testada com $\phi_{3}$ é que existe raiz unitária e que o modelo não possui tendência determinista.

Se a hipótese de presença de raiz unitária não for rejeitada, testa-se o modelo com a presença de constante, usando a estatística $\tau_{\mu}$. A ausência de constante e a presença de raiz unitária é testada em conjunto por $\phi_{1}$. $O$ último teste é para o modelo sem constante e sem tendência. A hipótese de nulidade é a existência de raiz unitária. Se o modelo apresentar raiz unitária com a variável em nível, é necessário realizar esse mesmo procedimento para a variável em uma diferença para constatar se existe somente uma raiz unitária.

\subsection{Método X11 e X11 ARIMA}

Dado o comportamento sazonal das séries de consumo, essas serão decompostas pelo método X11 (U.S. Departement of Commerce, 1976) ${ }^{40}$. Esse método baseia-se na decomposição da série original $\left(O_{t}\right)$ em quatro componentes: sazonal $\left(S_{t}\right)$, ciclo-tendência $\left(C_{t}\right)$, efeitos do calendário $\left(D_{t}\right)$ e irregular $\left(I_{t}\right)$. Assim, o componente sazonal capta os ciclos sistemáticos de período igual ou inferior a um ano, que é repetida constantemente ou em desenvolvimento de ano para ano. O componente ciclo-tendência inclui

40 A base do método foi desenvolvida no final da década de 20 , e baseia-se na razão (ou diferença) de médias móveis (U.S. Departement of Commerce, 1976). 
variação de tendência de longo prazo, ciclos econômicos e outros fatores cíclicos de longo prazo. O terceiro componente, efeito de calendário é devido à diferença de dias entre os meses do ano ou efeitos de calendário, como sábado, domingo ou feriado. O último é responsável pela variação residual final (SAS Institute, 1994). O método X11 consiste em sucessivas filtragens ${ }^{41}$, pela aplicação de filtros lineares. O modelo a ser usado para separar os componentes da série é multiplicativo (22), como segue:

$$
O_{t}=S_{t} \cdot C_{t} \cdot D_{t} \cdot I_{t}
$$

onde, $O_{t}$ representa cada uma das três séries de consumo.

Nesse modelo, $C_{t}$ tem a mesma unidade que $O_{t} . S_{t}, C_{t}$ e $I_{t}$ são expressos em \% e tem valores ao redor de 100 .

$\mathrm{O}$ método $\mathrm{X} 11$ usa um conjunto de médias móveis centradas para estimar os componentes sazonais. Essa média móvel aplica pesos simétricos para todas as observações, exceto para aquelas do início e final das séries.

\section{3 - Os Modelos Box-Jenkins}

Nazen (1996) justifica o uso de modelos SARIMA (auto-regressivo integrado sazonal de média móveis) para estimar a demanda de água, pois o uso da água depende de muitos fatores relacionados ao tempo e também um componente sazonal, com aumento de consumo no verão. $A$ água consumida em uma residência é função de características pessoais e de hábitos locais. Boa parte deste consumo é para higiene básica da casa, apresentando um componente auto-regressivo.

O modelo univariado utiliza o método desenvolvido por Box, Jenkins e Reinsel (1994) para séries temporais. Inicialmente desenvolvido por Box e

\footnotetext{
${ }^{41}$ Para maiores detalhes ver Pino et al. (1994).
} 
Jenkins (1976), o método baseia-se na idéia que a série temporal pode ser parcialmente explicada por ela mesma, através de parâmetros auto-regressivos que podem explicar realizações anteriores. As médias móveis servem para explicar os erros passados.

Os modelos auto-regressivos integrados de médias móveis podem ser representados em sua forma geral por:

$$
Y_{t}=\frac{\theta(\mathrm{B})}{\phi(\mathrm{B})} a_{t}
$$

onde:

$Y_{t}$ é a variável em nível, e $B$ é o operador de atraso, tal que $B^{j} y_{t}=y_{t-j}$;

$$
\phi(B)=1-\phi_{1} B-\phi_{2} B^{2}-\ldots-\phi_{p} B^{p} \text { é o operador auto-regressivo de }
$$
ordem $p ; \mathrm{e}$

$\theta(B)=1+\theta_{1} B+\theta_{2} B^{2}+\ldots+\theta_{q} B^{q}$ é o operador de média móvel de ordem $q$.

O teste de raiz unitária permite achar o valor de $d$ que toma a série estacionária. Após obter uma série estacionária, o passo seguinte é identificar o processo gerador da série, através das funções de auto-correlação regular e parcial. $O$ resíduo do modelo deverá apresentar característica de ruído branco, ou seja, ser aleatório, com distribuição normal (Margarido e Souza, 1998).

\subsection{Função de Transferência}

Apesar de alguns trabalhos no Brasil não terem encontrado significância para as variáveis relacionadas a clima (temperatura e precipitação) espera-se que para o modelo de séries temporais essas variáveis expliquem 
parte da variação no consumo de água, especialmente a temperatura (Mattos, 1999 e Andrade et al., 1996). Por essa razão, é necessário um modelo com abordagem multivariada ou mais comumente conhecido como modelo de função de transferência.

O modelo de função de transferência é baseado no modelo de defasagem distribuída. (Vandaele 1983). Esse modelo é representado pelo nível da variável dependente $Y_{t}$ como sendo função direta do número de valores passados da variável independente $X_{t}$. Uma mudança na série de entrada pode não se manifestar de forma imediata sobre a série de saída, assim, pode existir uma defasagem temporal entre a variação ocorrida na variável exógena e seu efeito sobre a variável endógena (Pino, 1980). modelo de função de transferência é apresentado a seguir:

$$
Y_{t}=\frac{\omega_{0}-\omega_{1} B-\ldots-\omega_{s} B^{s}}{1-\delta_{1} B-\ldots-\delta_{r} B^{r}} X_{t-b}+\frac{\theta(B)}{\phi(B)} a_{t}
$$

onde:

$Y_{t}$ é a variável endógena;

$X_{i}($ com $i=1, \ldots, n)$ são as variáveis exógenas;

$\theta(B)$ é o operador de média móvel;

$\phi(B)$ é o operador auto-regressivo;

$\omega(B)$ representa os impactos de curto prazo;

$\delta(B)$ representa o fator de ajuste de longo prazo; e

b é o parâmetro do impacto inicial da série de entrada $X$ sobre a série da saída $Y$. 


\section{RESULTADOS}

\section{6:1. Consumo Residencial Médio}

\subsubsection{O método $X 11$}

Analisando a série de consumo residencial médio pode-se perceber a forte influência sazonal. Esse fato é confirmado pelo teste $F$ para a sazonalidade estável entre meses. Esse fato não é confimado para a sazonalịdade móvel, como pode ser visto na Tabela 4.

Tabela 4: Resultado dos testes de sazonalidade estável e móvel para consumo residencial médio, Piracicaba, janeiro de 1990 a dezembro de 1999.

\begin{tabular}{rrrrr}
\hline Estável & Soma dos quadrados & Graus de liberdade & Média dos quadrados & $F$ \\
\hline Entre Meses & 1679,810 & 11 & 152,710 & 6,118 \\
Erro & 2695,581 & 108 & 24,959 & \\
Total & 4375,391 & 119 & & \\
\hline
\end{tabular}

A probabilidade de um F maior é menor que 0,0001

Teste para Sazonalidade Móvel - Consumo Total

Móvel Soma dos quadrados grau de liberdade Média dos quadrados $F$

Entre Anos

1510300,25

9

167811,138

1,209

Erro 13743988,4

99

138828,166

A probabilidade de um $\mathrm{F}$ maior é menor que 0.2983

Fonte: Resultado da pesquisa.

A comparação gráfica entre a série original e a série sazonalmente ajustada pelo método $\times 11$ é apresentada na Figura 11. A série sazonalmente ajustada apresenta menores picos que a original, como o previsto pelo método. Os fatores sazonais estão plotados na Figura 12. Existe um pico de consumo 
nos meses quentes de verão e um vale, representando uma queda no consumo, nos meses frios. A diferença entre o maior e menor consumo está em torno de $15 \%$, abaixo da diferença de consumo observado por Griffin e Chang para o Texas, onde essa diferença chegou a mais de $70 \%$ (de 130,8 a 226,0 gal/capita/dia).

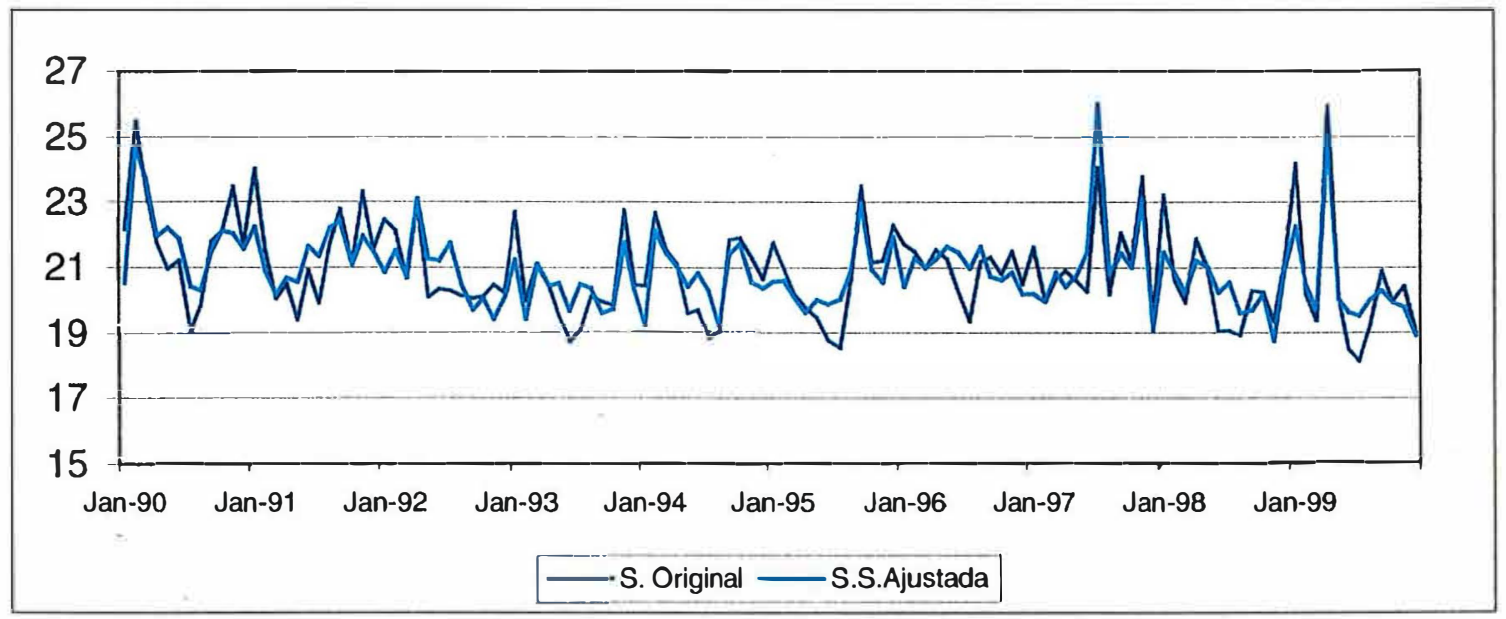

Figura 11: Série original e sazonalmente ajustada do consumo médio mensal residencial de água, em m²/ligação, Piracicaba, janeiro de 1990 a dezembro de 1999.

Fonte: Resultados da pesquisa. 


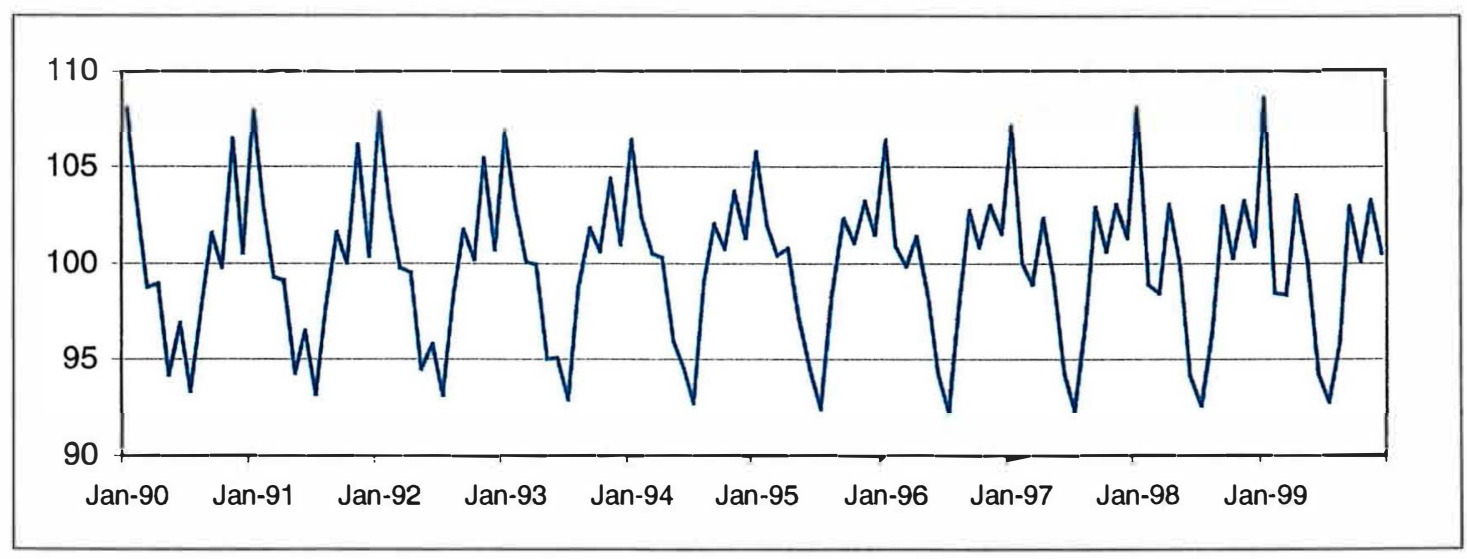

Figura 11: Fatores sazonais para do consumo médio residencial mensal de água, em \%, Piracicaba, janeiro de 1990 a dezembro de 1999.

Fonte: Resultados da pesquisa.

A Figura 10 mostra ainda uma tendência de queda nas duas séries, original e sazonalmente ajustada. Esse fato pode ser confirmado pela série de ciclo-tendência (Figura 12), que mostra uma queda maior no período até 1994. No período seguinte, até 1998 , ela cresce ligeiramente, voltando a cairaté o final da série.

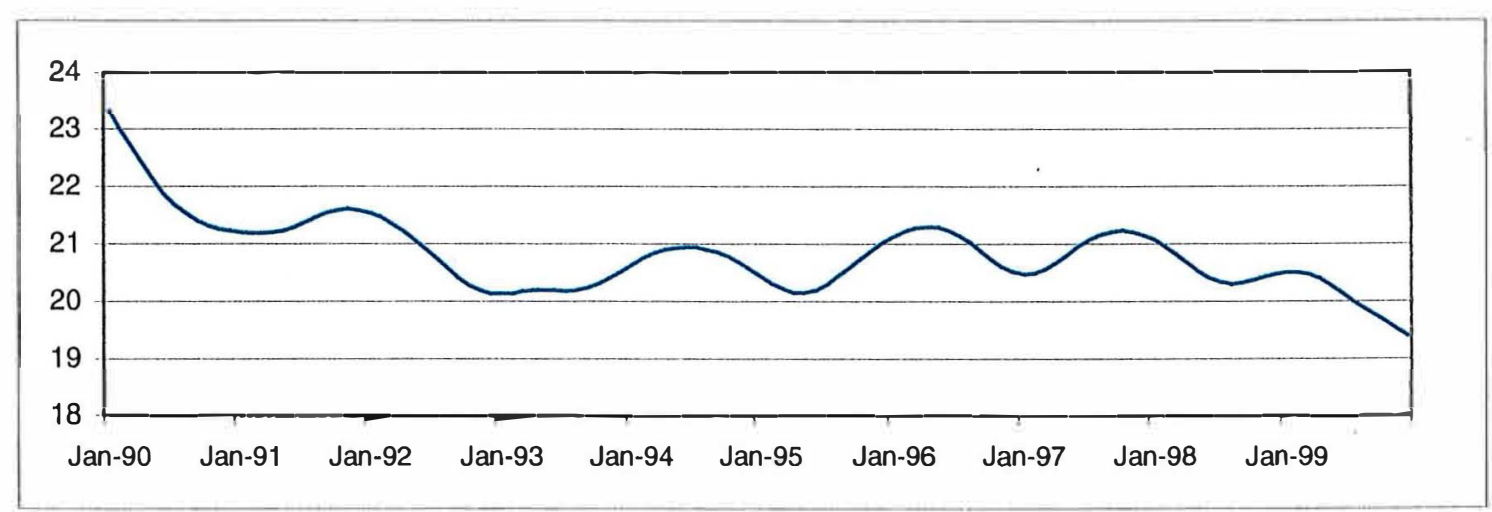

Figura 12: Série ciclo-tendência final do consumo médio mensal residencial de água, em $\mathrm{m}^{3} /$ ligação, Piracicaba, janeiro de 1990 a dezembro de 1999.

Fonte: Resultados da pesquisa. 


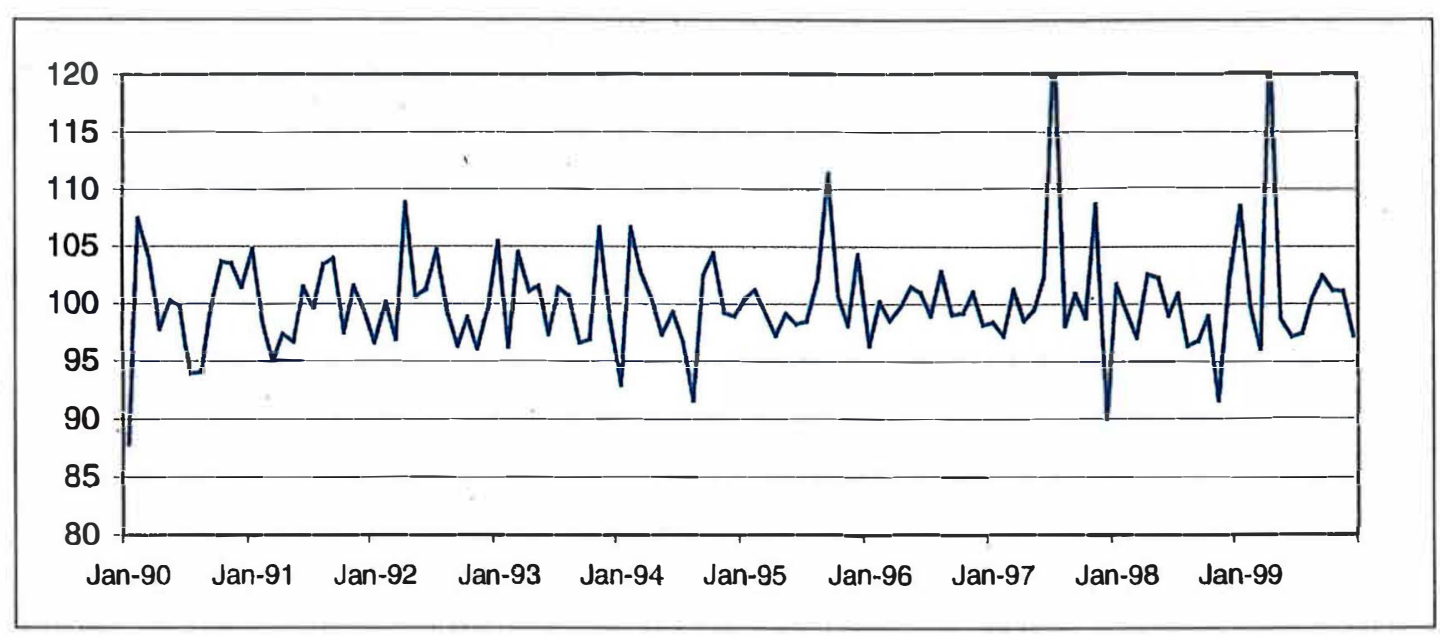

Figura 13: Série irregular final do consumo médio mensal residencial de água, Piracicaba, em \%, janeiro de 1990 a dezembro de 1999.

Fonte: Resultados da pesquisa.

A série irregular ${ }^{42}$ é apresentada na Figura 13. Os maiores picos e vales aparecem na série após 1997, com picos de aumento no consumo médio. Muito desses picos devem estar relacionados com a leitura dos hidrômetros, que não é feita regularmente.

\subsubsection{Teste de raiz unitária}

Analisando o modelo contendo constante e tendência (Trenc) o valor calculado de $\tau_{\tau}(-8,6060)$ é maior em módulo que o tabelado por Mackinnon (1991), para 1\%. Dessa forma, a hipótese nula de raiz unitária é rejeita e CMR pode ser estacionária. $O$ valor calculado para a estatística $\phi_{3}$ foi de 37,0338 maior que o tabelado por Dickey e Fuller (1981) para 1\% de significância. Assim, rejeita-se a hipótese de que a série de consumo médio mensal apresenta raiz unitária e o modelo possui constante e tendência. Como pode ser vizualizado pelo gráfico da série.

42 Essa analise é importante pois capta os efeitos eventuais. SE a série for de preços, no período dos planos econômicos, a série irregular apresentava muitos picos e vales. 


\subsubsection{Modelos univariados}

Dois modelos ARIMA apresentaram melhores ajuste para a variável CMR. O primeiro foi um auto-regressivo sazonal multiplicativo de ordens 1 e 12, com uma constante $\left(\theta_{0}\right)$, ou seja:

$$
(1-0,2171 B)\left(1-0,3171 B^{12}\right) C M R=20,9496+a_{\ell}
$$

O segundo modelo apresenta valor significativo no lag 5 , além da 1 e 12, porém este é aditivo, como segue:

$$
\left(1-0,1800 B+0,1946 B^{5}-0,2745 B^{12}\right) C M R=20,9284+a_{t}
$$

Foram selecionados os dois modelos acima, pois os critérios de AIC e SBC deram resultados diferentes. Pelo critério de AIC o modelo selecionado seria o aditivo $(418,6<420,3)$ e pelo SBC o modelo seria o multiplicativo $(428,6<429,7)$.

Os detalhes do resultado podem ser visto em detalhes na Tabela 5, onde estão as estatísticas dos modelos. 
Tabela 5. Estimativas dos parâmetros dos modelos univariados e do modelo de função de transferência para o consumo médio residencial de água, Piracicaba, janeiro de 1990 a dezembro de 1999.

\begin{tabular}{|c|c|c|c|}
\hline Modelo & Parâmetro & Estimativa & Teste t \\
\hline \multirow[t]{4}{*}{ ARIMA aditivo } & $\phi_{1}$ & $\begin{array}{l}0,1800 \\
(0,0889)\end{array}$ & 2,03 \\
\hline & $\phi_{5}$ & $\begin{array}{r}-0,1946 \\
(0,0870)\end{array}$ & $-2,24$ \\
\hline & $\phi_{12}$ & $\begin{array}{l}0,2754 \\
(0,1013)\end{array}$ & 2,69 \\
\hline & constante & $\begin{array}{c}20,9284 \\
(0,1624)\end{array}$ & 128.83 \\
\hline \multirow[t]{3}{*}{ ARIMA sazonal } & $\phi_{1}$ & $\begin{array}{l}0,2171 \\
(0,0925)\end{array}$ & 2,35 \\
\hline & $\phi_{12}$ & $\begin{array}{l}0,3137 \\
(0,1053)\end{array}$ & 2,98 \\
\hline & constante & $\begin{array}{c}20,9496 \\
(0,2209)\end{array}$ & 94,83 \\
\hline \multirow[t]{5}{*}{$\begin{array}{l}\text { Função de } \\
\text { Transferência }\end{array}$} & $\phi_{1}$ & $\begin{array}{l}0,1185 \\
(0,0916)\end{array}$ & 1,29 \\
\hline & $\phi_{5}$ & $\begin{array}{c}-0,1168 \\
(0,0898)\end{array}$ & $-1,30$ \\
\hline & $\phi_{12}$ & $\begin{array}{l}0,2822 \\
(0,1025)\end{array}$ & 2,75 \\
\hline & $\omega_{0}\left(T_{t-1}\right)$ & $\begin{array}{l}0,2381 \\
(0,0686)\end{array}$ & 3,47 \\
\hline & constante & $\begin{array}{c}15,6648 \\
(1,5250)\end{array}$ & 10,27 \\
\hline
\end{tabular}

Fonte: Resultado da pesquisa.

\subsubsection{Função de transferência}

Os modelos de função de transferência testaram as seguintes variáveis: Temperatura, Precipitação, Preço Médio e Preço Marginal. Somente a variável temperatura foi significativa para explicar a quantidade consumida de água, usada com uma defasagem, isto é, a temperatura do mês anterior influência o consumo médio residencial de água no mês em questão. $O$ modelo que apresentou melhor resultado foi:

$$
\left(1-0,1185 B+0,1168 B^{5}-0,2822 B^{12}\right) C M R=15,6648+0,2381 T_{t-1}
$$


Essa equação mostra que a temperatura tem relação direta com o consumo médio de água em Piracicaba e os pelos critérios de AIC e SBC (406,6 e 420,5 respectivamente), este é o melhor modelo encontrado, superior aos univariados. As estatísticas do modelo são encontradas na Tabela 5. Apesar da estatística $t$ não ser significativa ao nível de $5 \%$ para os parâmetros nas defasagens 1 e 5, o modelo escolhido incluindo esses lags foi superior pelos critérios de AIC e SBC que o modelo excluindo.

\subsection{Consumo Residencial Total}

\subsubsection{O método $X 11$}

A série de consumo residencial total apresenta sazonalidade, como pode ser visto na Figura 14. O teste F para a sazonalidade estável entre meses é significativo a menos de1\%, confirmando a presença de sazonalidade. Porém, para a sazonalidade móvel, esse fato não é confirmado, como pode ser visto na Tabela 6.

Tabela 6:Resultado dos testes de sazonalidade estável e móvel para consumo residencial médio, Piracicaba, janeiro de 1990 a dezembro de 1999.

\begin{tabular}{rrrrr}
\hline \multicolumn{1}{c}{ Estável } & Soma dos guadrados & graus de liberdade & Média dos quadrados & F \\
\hline Entre Meses & 1703,772 & 11 & 154,888 & 6,059 \\
Erro & 2760,733 & 108 & 25,562 & \\
Total & 4464,506 & 119 & & \\
\hline
\end{tabular}

Probabilidade de um maior $F$ é $<0,0001$

\begin{tabular}{rrrrrr}
\hline Móvel & Soma dos quadrados & grau de liberdade & Média dos quadrados & $F$ & \\
\hline Entre Anos & 1508101,85 & 9 & 167566,873 & 1,171 \\
Erro & 14166445,5 & 99 & 143095,409 & \\
\hline
\end{tabular}

A probabilidade de um $\mathrm{F}$ maior é menor que 0,3219

Fonte: Resultado da pesquisa.

Comparando os gráficos das séries original e sazonalmente ajustada pelo método X11 (Figura 14), pode-se perceber que a série ajustada é mais 
suave que a original. Na Figura 15 são apresentados os fatores sazonais, onde os picos de consumo aparecem nos meses de verão e os vales nos meses de inverno. Como na série de consumo médio residencial, a maior amplitude de variação entre picos e vales está em torno de $15 \%$.

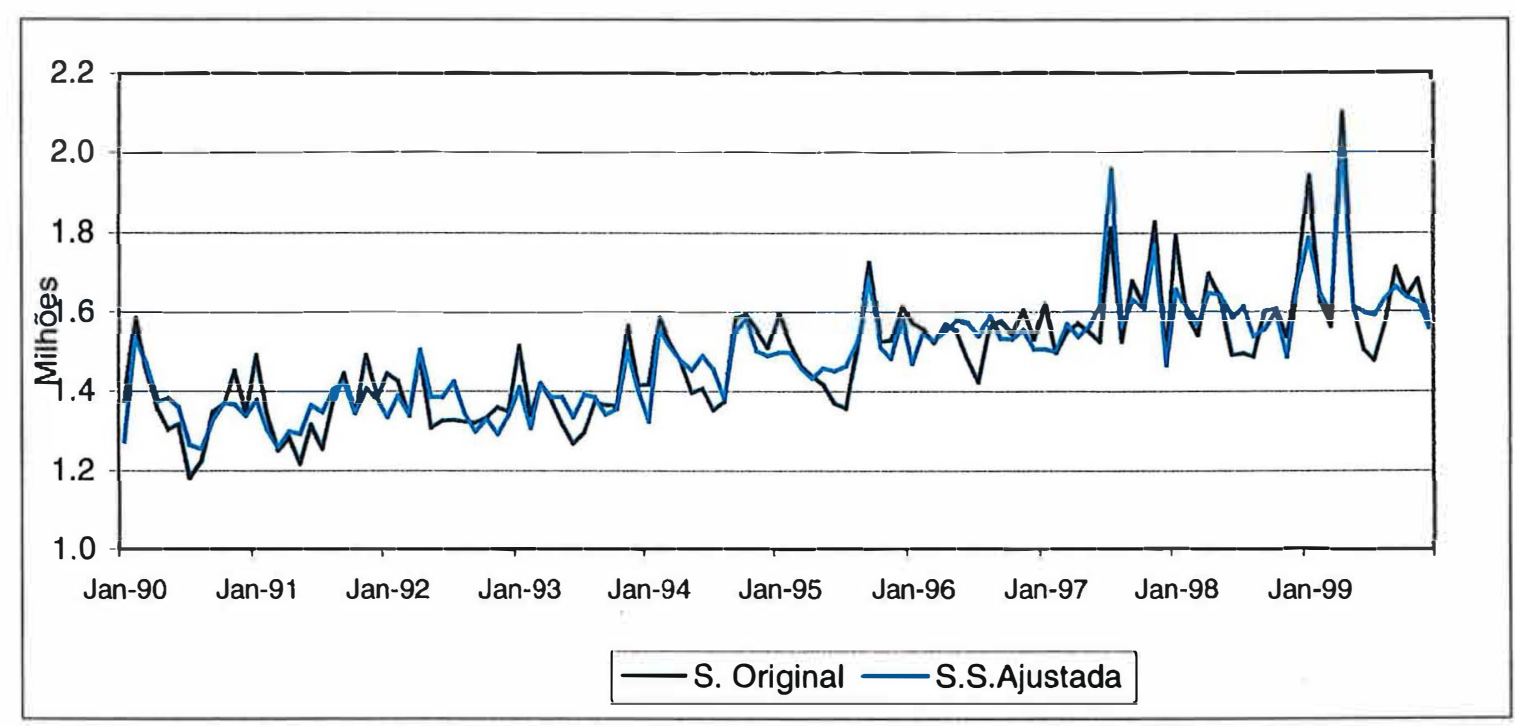

Figura 14. Série original e sazonalmente ajustada do consumo residencial mensal de água, em milhões de $\mathrm{m}^{3}$, Piracicaba, janeiro de 1990 a dezembro de 1999.

Fonte: Resultados da pesquisa. 


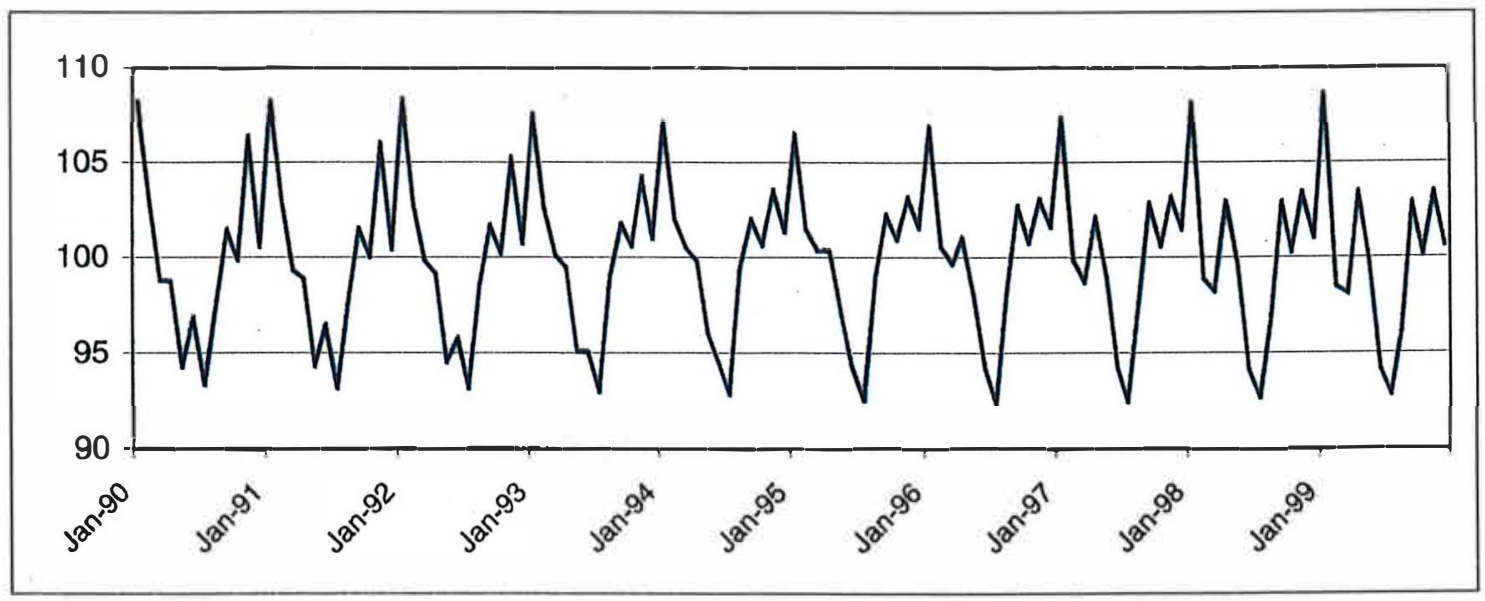

Figura 15. Fatores sazonais mensal para a série de consumo residencial de água, Piracicaba, em \%, janeiro de 1990 a dezembro de 1999.

Fonte: Resultados da pesquisa.

Existe um crescimento no consumo residencial de água, como mostra a Figura 10, nas duas séries, original e sazonalmente ajustada. Fato confirmado pela série de ciclo-tendência (Figura 14), que mostra um consumo estável até 1993 e a partir daí, uma tendência de crescimento constante, só diminuindo no final da série. A série irregular é apresentada na Figura 17, onde os pontos extremos aparecem na série após 1997, da mesma maneira que a série de consumo médio residencial. 


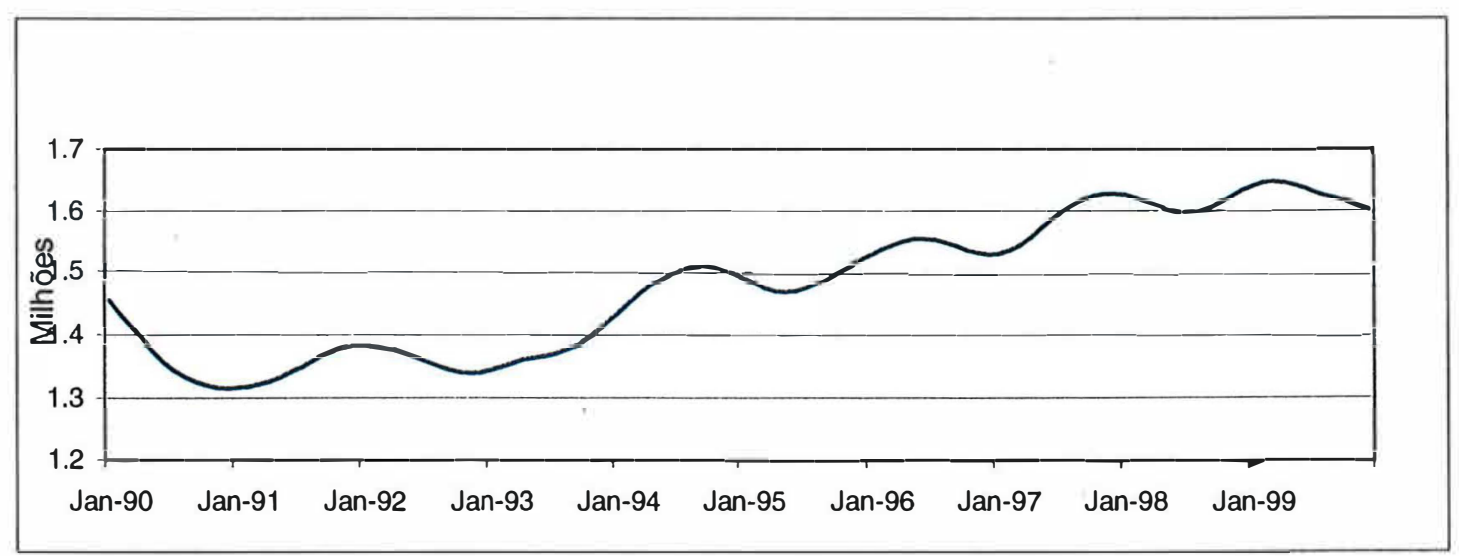

Figura 16: Série ciclo-tendência final para consumo residencial mensal de água, Piracicaba, janeiro de 1990 a dezembro de 1999.

Fonte: Resultados da pesquisa.

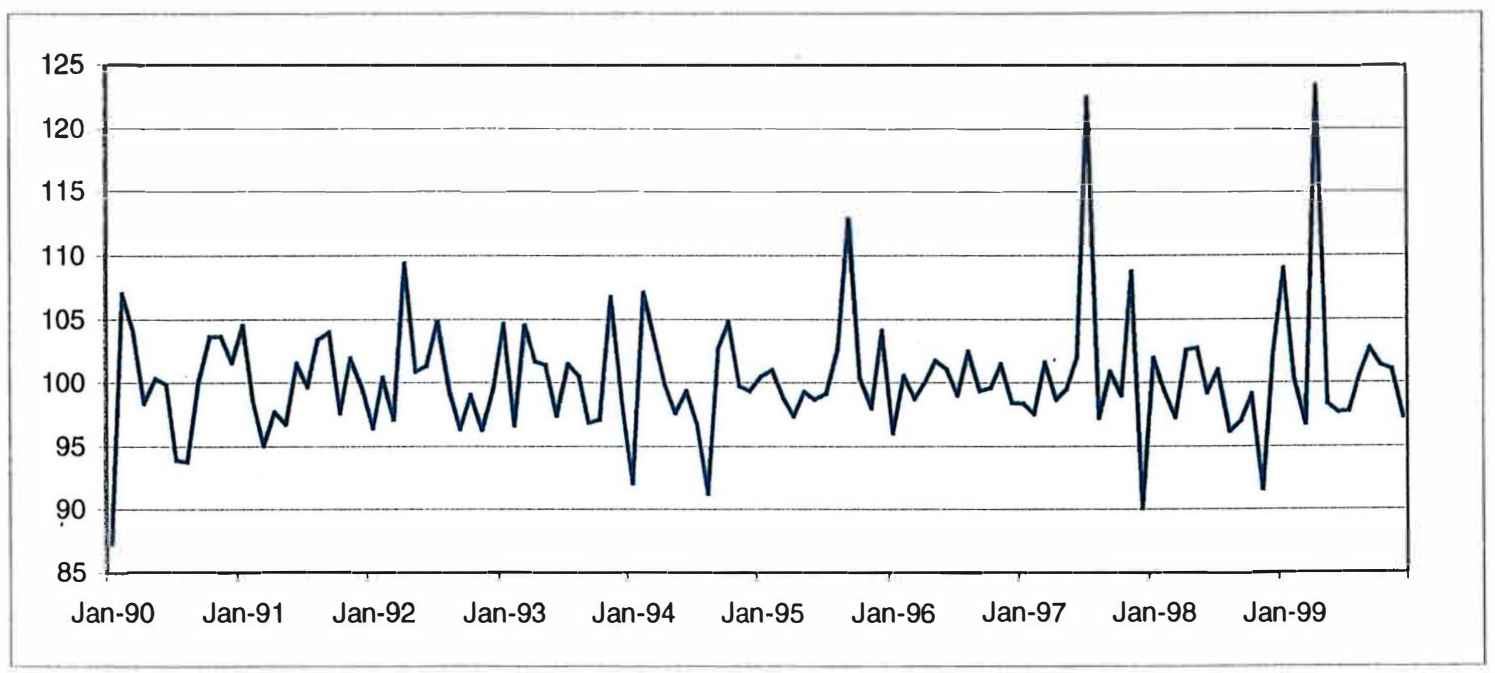

Figura 17: Série irregular final para consumo mensal residencial de água, Piracicaba, janeiro de 1990 a dezembro de 1999.

Fonte: Resultados da pesquisa. 


\subsubsection{Teste de raiz unitária}

No modelo contendo constante e tendência (Trend) o valor calculado de $\tau_{\tau}(-9,0458)$ é maior, em módulo, que o tabelado por Mackinnon (1991), para $1 \%$, rejeitando a hipótese de nulidade. Assim, CR pode ser aparentemente estacionária. Continuando o teste, o valor calculado da estatística $\phi_{3}$ é 40,9136 maior que o tabelado por Dickey e Fuller (1981) para $1 \%$ de significância. Portanto, o modelo apresenta constante e tendência e a série de consumo residencial, não apresenta raiz unitária.

\subsubsection{Modelos univariados}

O resultado do teste de raiz unitária indica que a série necessita de diferença para se tomar estacionária e os resultados dos modelos testados foram melhores após uma diferença na série. Assim, o modelo ARIMA que melhor se ajustou para a variável CR foi:

$$
\left(1+0,2340 B^{5}+0,1877 B^{6}-0,2426 B^{12}\right)(1-B) C R=2499+\frac{1}{1-0,8806 B} a_{1}
$$

Pelo critério de AIC e SBC o modelo acima é superior até aos modelos de função de transferência. A estatística do modelo pode ser vista na Tabela 7. 
Tabela 7. Estimativas dos parâmetros do modelo univariado e do modelo de função de transferência para o consumo residencial total, Piracicaba, janeiro de 1990 a dezembro de 1999.

\begin{tabular}{lccc}
\hline Modelo & Parâmetro & \multicolumn{1}{c}{ Estimativa } & Teste t \\
\hline ARIMA aditivo & $\theta_{1}$ & 0,8806 & 18,31 \\
& $\phi_{5}$ & $(0,0481)$ & $-0,2340$ \\
& $\phi_{6}$ & $(0,09032)$ & $-2,59$ \\
& $-0,1877$ & $-2,00$ \\
$\phi_{12}$ & $(0,0938)$ & 2,21 \\
& Constante & $\begin{array}{l}0,2426 \\
(0,1096)\end{array}$ & 2,59 \\
& $(0,9284$ & $2,1624)$ & 2 \\
\hline
\end{tabular}

Fonte: Resultado da pesquisa.

\subsection{Consumo Total}

\subsubsection{O método $X 11$}

A série de consumo total apresenta um componente sazonal. Esse fato é confirmado pelo teste $F$ para a sazonalidade estável entre meses. Para a sazonalidade móvel, isto é, entre anos, o teste $F$ não é conclusivo, como pode ser visto na Tabela 8. 
Tabela 8: Resultado dos testes de sazonalidade estável e móvel para consumo total mensal, Piracicaba, janeiro de 1990 a dezembro de 1999.

\begin{tabular}{rrrrr}
\hline Estável & Soma dos quadrados & graus de liberdade & Média dos quadrados & F \\
\hline Entre Meses & 1444,003 & 11 & 131,273 & 6.239 \\
Erro & 2272,310 & 108 & 21,040 & \\
Total & 3716,313 & 119 & & \\
\hline
\end{tabular}

A probabilidade de um $F$ maior $F<0,0001$

Móvel Soma dos quadrados grau de liberdade Média dos quadrados $\mathrm{F}$

\begin{tabular}{rrrrr} 
Entre Anos & 1422571,86 & 9 & 158063,540 & 1,396 \\
Erro & 11208172,4 & 99 & 113213,863 & \\
\hline
\end{tabular}

Probabilidade de um maior $\mathrm{F}$ é $<0,2001$

Fonte: Resultado da pesquisa.

Comparando as duas séries, a original e a sazonalmente ajustada percebe-se que a série ajustada pelo método X11 tem comportamento mais suave. Dessa forma, a série sazonalmente ajustada apresenta picos e vales menores que a original, como pode ser visto na Figura 18.

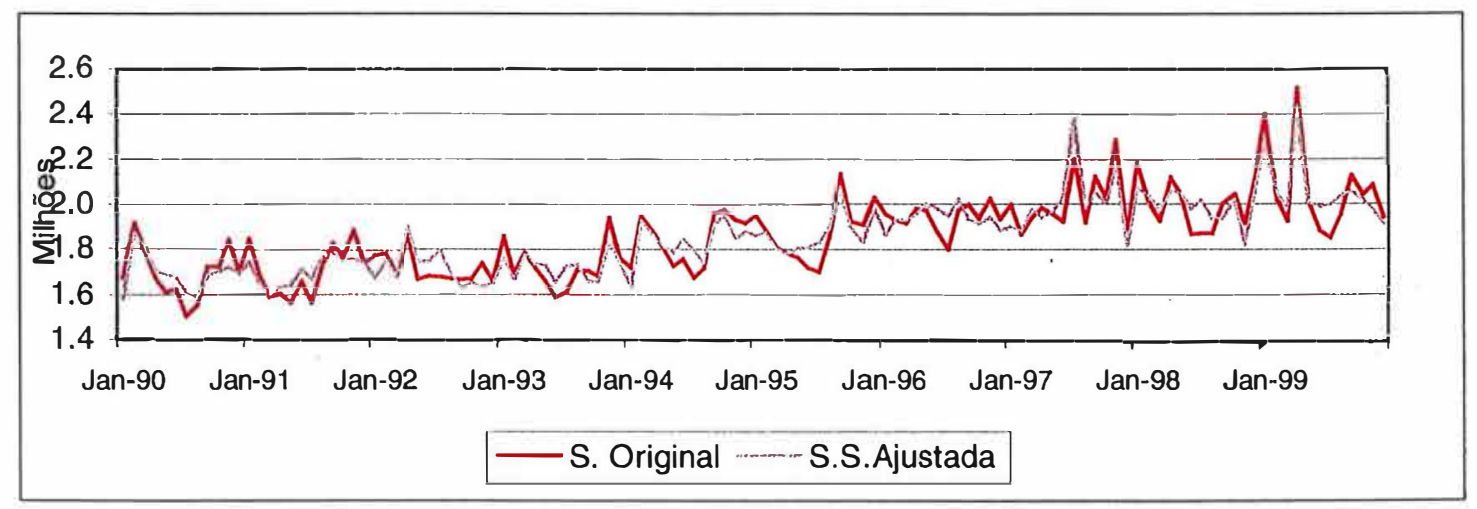

Figura 18. Série original e sazonalmente ajustada do consumo total mensal de água, em milhões de $\mathrm{m}^{3}$, Piracicaba, janeiro de 1990 a dezembro de 1999.

Fonte: Resultados da pesquisa.

Os fatores sazonais são apresentados na Figura 19. Como nos casos anteriores, os picos de consumo acontecem nos meses verão e os vales, no 
inverno. A diferença entre o maior e menor consumo nesse caso é menor que para as séries de consumo residencial. A série de consumo total é a soma de todos os consumos, e a série que apresenta maior sazonalidade é a de consumo residencial. Por essa razão, os fatores sazonais são menores quando se trata do total

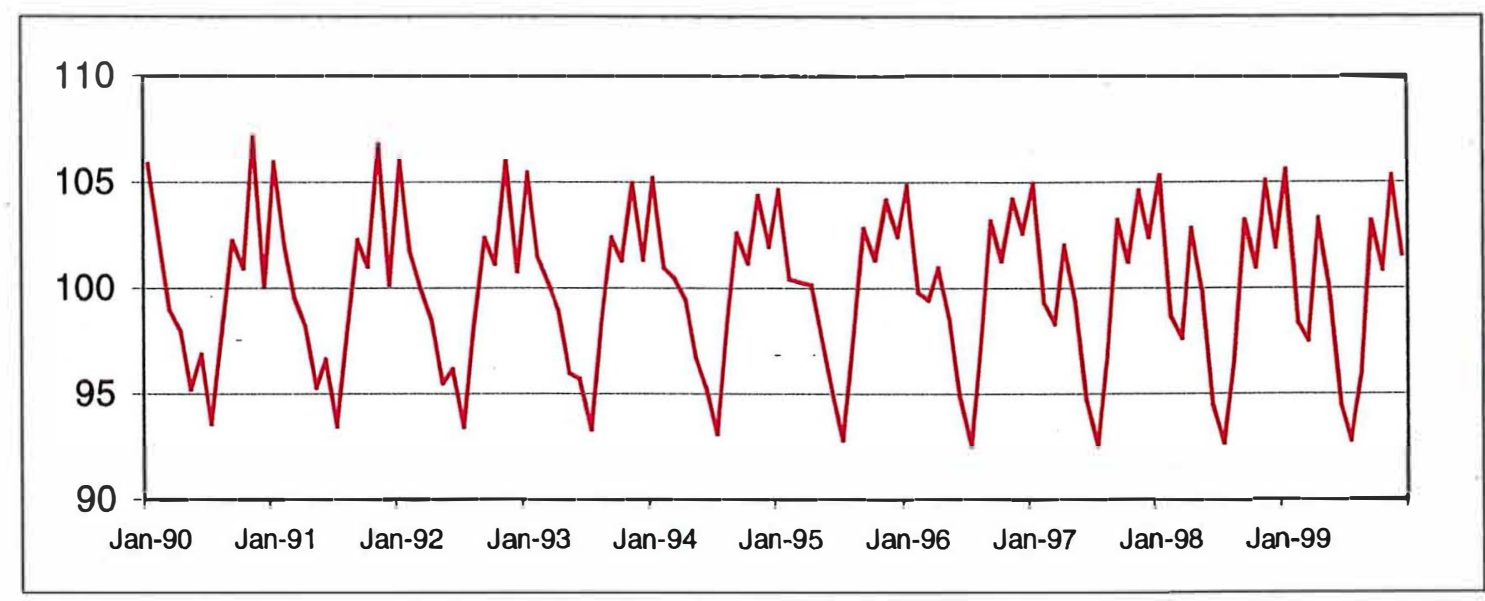

Figura 19: Fatores sazonais mensais para a série de consumo total de água, Piracicaba, em \%, janeiro de 1990 a dezembro de 1999.

Fonte: Resultados da pesquisa.

$\mathrm{Na}$ série original, na Figura 18, já se percebe uma tendência de crescimento no consumo total, fato confirmado pela série de ciclo-tendência (Figura 20). A série mostra uma certa estabilidade no período até 1994 , crescendo a partir daí até o final da série.

A série irregular é apresentada na Figura 21. Os maiores picos e vales aparecem na série após 1997, com picos de aumento no consumo médio. Muito desses picos devem estar relacionados com a leitura dos hidrômetros, que não é feita regularmente. 


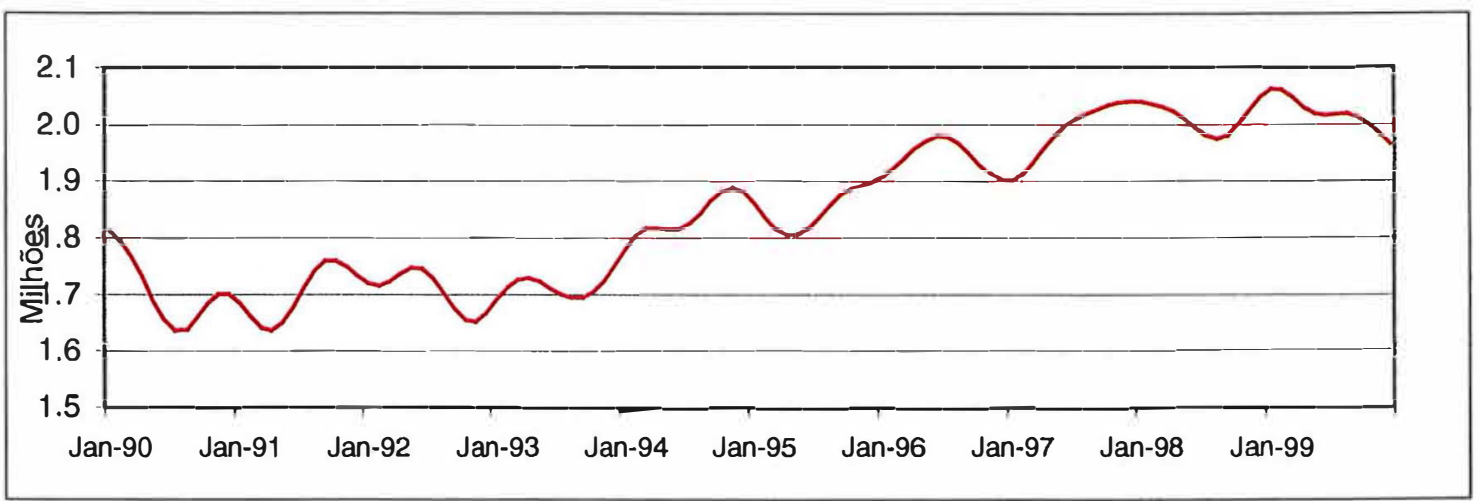

Figura 20: Série ciclo-tendência final para o consumo total mensal de água para Piracicaba, em milhões de $\mathrm{m}^{3}$, janeiro de 1990 a dezembro de 1999.

Fonte: Resultados da pesquisa.

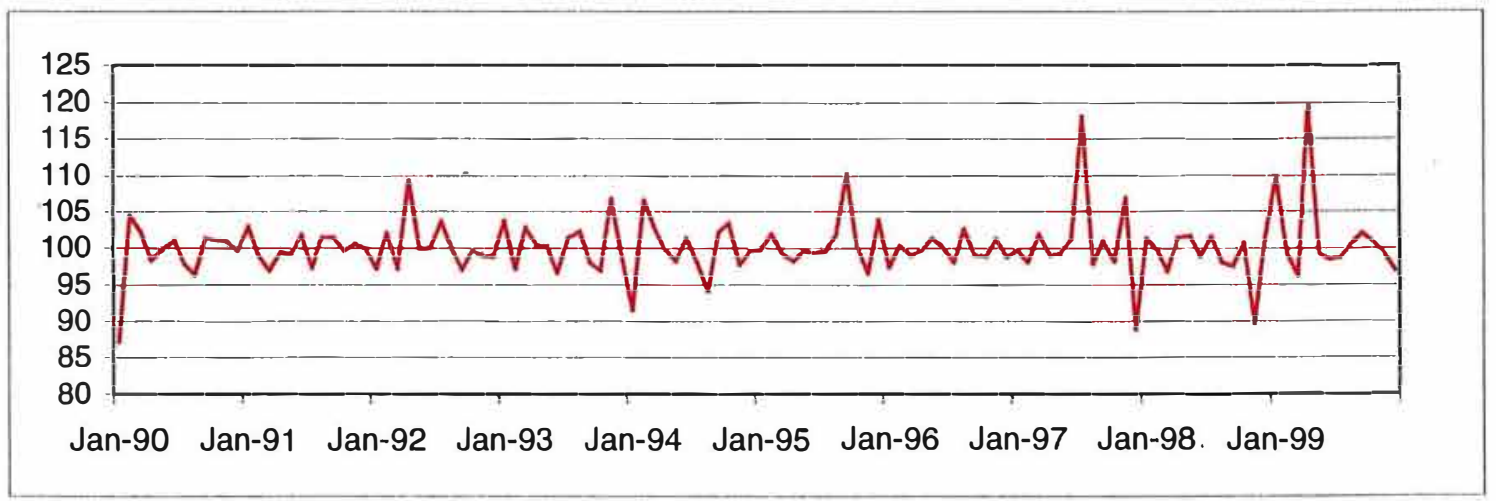

Figura 21: Série irregular final para consumo total mensal de água para Piracicaba, em \%, janeiro de 1990 a dezembro de 1999.

Fonte: Resultados da pesquisa. 


\subsubsection{Teste de raiz unitária}

Analisando o modelo contendo constante e tendência (Trend) o valor calculado de $\tau_{\tau}(-8,7771)$ é maior em módulo que o tabelado por Mackinnon (1991) para 1\%. A hipótese nula de raiz unitária é rejeita e CT pode ser estacionária. Usando a estatística $\phi_{3} \circ$ valor calculado para esta estatística, 38,5263, é maior que o tabelado por Dickey e Fuller (1981) para $1 \%$ de significância. Assim, rejeita-se a hipótese de que a série de consumo mensal apresenta raiz unitária. Logo pode-se afirmar que a série CT é estacionária com tendência linear.

\subsubsection{Modelos univariados}

O modelo ARIMA que melhor se ajustou para a variável CT sem diferença foi:

$$
\left(1-0,5303 B-0,28281 B^{7}\right) C T=1814523,3+a t
$$

Porém esse modelo apresenta valores altos para os critérios de AIC e SBC (3170,6 e 3179,0 respectivamente). Desta forma, apesar do teste de raiz unitária não recomendar, modelo para CT com uso da variável diferenciada apresentou melhores resultados. Assim, o segundo modelo univariado ficou:

$$
\left(1-0,10905 B+0,2351 B^{5}-0,2798 B^{12}\right) C T=3400,9+\frac{a_{t}}{1-0,9538}
$$

O modelo acima, apresentou melhores resultados, pois os critérios de AIC e SBC foram menores (3111,9 e 3125,8 respectivamente). Os detalhes dos resultados podem ser visto em detalhes na Tabela 9, onde são apresentadas as estatísticas dos modelos. 
Tabela 9. Estimativas dos parâmetros dos modelos univariados e do modelo de função de transferência para o consumo total médio residencial, Piracicaba, janeiro de 1990 a dezembro de 1999.

\begin{tabular}{|c|c|c|c|}
\hline Modelo & Parâmetro & Estimativa & Teste t \\
\hline \multirow[t]{3}{*}{ ARMA } & $\phi_{1}$ & $\begin{array}{l}0,5303 \\
(0,0750)\end{array}$ & 7,07 \\
\hline & $\phi_{7}$ & $\begin{array}{l}0,2828 \\
(0,0870)\end{array}$ & 3,65 \\
\hline & constante & $\begin{array}{c}1814523 \\
(52814)\end{array}$ & 34,36 \\
\hline \multirow[t]{5}{*}{ ARIMA } & $\theta_{1}$ & $\begin{array}{l}0,9538 \\
(0,0315)\end{array}$ & 30,27 \\
\hline & $\phi_{1}$ & $\begin{array}{l}0,1091 \\
(0,0952)\end{array}$ & 1,17 \\
\hline & $\phi_{5}$ & $\begin{array}{r}-0,2351 \\
(0,0938)\end{array}$ & $-2,52$ \\
\hline & $\phi_{12}$ & $\begin{array}{l}0,2798 \\
(0,1085)\end{array}$ & 2,21 \\
\hline & constante & $\begin{array}{c}20,9284 \\
(0,1624)\end{array}$ & 2,58 \\
\hline \multirow[t]{6}{*}{$\begin{array}{l}\text { Função de } \\
\text { Transferência }\end{array}$} & $\theta_{1}$ & $\begin{array}{l}-0,2252 \\
(0,0965)\end{array}$ & $-2,33$ \\
\hline & $\phi_{1}$ & $\begin{array}{l}0,1455 \\
(0,0894)\end{array}$ & 1,63 \\
\hline & $\phi_{7}$ & $\begin{array}{l}0,3146 \\
(0,0823)\end{array}$ & 3,82 \\
\hline & $\phi_{12}$ & $\begin{array}{l}0,5013 \\
(0,1054)\end{array}$ & 4,76 \\
\hline & $\omega_{0}\left(T_{t}\right)$ & $\begin{array}{l}14896 \\
(5142)\end{array}$ & 2,90 \\
\hline & constante & $\begin{array}{c}1537064 \\
(2562) \\
\end{array}$ & 6,00 \\
\hline \multirow[t]{6}{*}{$\begin{array}{l}\text { Função de } \\
\text { Transferência }\end{array}$} & $\theta_{2}$ & $\begin{array}{l}-0,0963 \\
(0,0988)\end{array}$ & $-0,97$ \\
\hline & $\phi_{1}$ & $\begin{array}{l}0,2417 \\
(0,0901)\end{array}$ & 2,68 \\
\hline & $\phi_{7}$ & $\begin{array}{l}0,2684 \\
(0,0739)\end{array}$ & 3,63 \\
\hline & $\phi_{12}$ & $\begin{array}{l}0,4868 \\
(0,0945)\end{array}$ & 5,15 \\
\hline & $\omega_{0}\left(T_{t-1}\right)$ & $\begin{array}{c}18312 \\
(6107)\end{array}$ & 3,00 \\
\hline & constante & $\begin{array}{r}1477020 \\
(697868) \\
\end{array}$ & 2,12 \\
\hline
\end{tabular}

Fonte: Resultado da pesquisa. 


\subsubsection{Função de transferência}

As seguintes variáveis foram testadas nos modelos de função de transferência: Temperatura, Precipitação, Preço Médio, Preço Marginal. A temperatura foi a única a explicar significativamente a quantidade consumida de água, usada em nível e com uma defasagem. Isto é, a temperatura do mês anterior influência o consumo médio residencial de água no mês em questão. 0 modelo que apresentou melhor resultado em nível foi:

$$
\left(1-0,1455 B-0,3146 B^{7}-0,50127 B^{12}\right) C M R=1537064+14896 T_{t-1}+\frac{1}{1+0,22517 B^{3}} a_{t}
$$

Essa equação mostra que a temperatura tem relação direta com o consumo médio de água em Piracicaba e os pelos critérios de AIC e SBC (3149,35 e 3166,07 respectivamente), este é o melhor modelo encontrado, para a variável temperatura em nível, superior aos univariados. As estatísticas do modelo são encontradas na Tabela 9.

Para a variável temperatura defasada de um mês foi o melhor modelo encontrado, como pode ser visto:

$$
\left(1-0,2417 B-0,26841 B^{7}-0,48681 B^{12}\right) C M R=1477019+18312,74 T_{t-1}+\frac{1}{1+0,0963 B^{2}} a_{t}
$$

Este foi o modelo encontrado com melhores resultados pelos dois critérios: AIC e SBC (3125,03 e 3141,71 respectivamente). 


\section{CONCLUSÃO}

Os resultados econométricos do presente trabalho mostram que 0 consumo de água em Piracicaba, SP, apresenta um forte componente sazonal. A variação do consumo é diretamente proporcional à temperatura, aumentando nos meses de verão e diminuindo nos meses de inverno. Este efeito é mais forte nas séries de consumo residencial médio e residencial total.

Por outro lado, a série de dados de consumo total engloba outros usos que são menos dependente da temperatura, tais como: consumo industrial; comercial; e, construção civil, entre outros. Portanto, esta última série mostrouse menos sensível ao efeito do clima e apresenta variações sazonais de menor amplitude.

Como tendência de longo prazo, é possível observar que o consumo total cresce no período analisado. Grande parte deste aumento tem como fonte o crescimento do consumo residencial. Esse aumento ocorre juntamente com o crescimento do número de ligações residenciais. Os demais consumos pouco se alteram nesses dez anos.

Uma outra característica interessante das séries de consumo total e consumo residencial total é o crescimento acentuado após 1995. Aparentemente, este comportamento pode estar relacionado com crescimento da economia, ocorrido após a implementação do Plano Real. Infelizmente, devido às limitações quanto aos dados disponíveis, este efeito não pôde ser incorporado nas análises realizadas. 
Por outro lado, a série de consumo residencial médio apresenta uma tendência de significativa queda no período. Uma das possíveis explicações para este fato seria que a expansão recente da rede de abastecimento de água ter ocorrido nas regiões periféricas da cidade, onde predominam famílias de menor poder aquisitivo e que demandam água em quantidade mais reduzida.

Outra possivel explicação seria a conscientização da população para a problemática da água no município e região, principalmente nos meses mais secos. É interessante observar, nesse sentido, que existe uma tendência de queda dos fatores sazonais de consumo de água nos meses de vale, correspondendo aos meses de inverno. Esta é a época mais crítica para o abastecimento devido à menor vazão dos rios e durante a qual a população está mais sensivel ao problema.

Diversos estudos mostrados na revisão apontam que o consumo residencial de água é diretamente proporcional à renda, aumentando também com o tamanho de residências, números de pessoas por residência, número de chuveiros por residência, entre outros. Infelizmente, a não incorporação deste tipo de variáveis no modelo é uma das principais limitações do presente trabalho. Aparentemente, os dados agregados para o município como um todo não permite captar, nos modelos estimados, a contribuição da renda que é, geralmente, uma importante variável de decisão para determinar o consumo de água. Tampouco foi possivel incluir outras variáveis indicativas de condições sócio-econômicas e demográficas.

Essa pode ter sido, também, a causa da inexistência de efeito das variáveis preço médio e preço marginal nos modelos testados. Ambos os preços não apresentaram parâmetros significativos nesses modelos. 0 mesmo aconteceu com a variável diferença. Provavelmente, a agregação dos dados mascarou o efeito dessas variáveis sobre como cada consumidor, 
individualmente, reage à tarifa de água que possui estrutura em blocos crescentes.

Por outro lado, uma das características dos modelos de séries temporais é fazerem boas previsões de curto prazo. Porém, na medida em que o período da previsão se estende, o seu intervalo de confiança aumenta rapidamente. Assim, os modelos estimados poderão ser usados com certa segurança, no planejamento das operações do SEMAE - Piracicaba, somente no curto prazo.

Um trabalho interessante nos modelos de séries temporais é a sua calibração ao longo do tempo visando não somente a melhoria de seu poder de previsão como, também, o teste de especificações alternativas. Assim, na medida em que novos dados se tornem disponiveis no SEMAE, as previsões dos diferentes modelos poderão ser comparadas e testadas. Esses novos dados podem ser incorporados nos modelos resultando em novas previsões mais confiáveis.

Outra área importante para pesquisa é trabalhar com dados de uma região geográfica mais ampla como, por exemplo, uma microbacia. A previsão da evolução do consumo de água dentro de uma microbacia poderá ter uma importância vital para o gerenciamento racional dos recursos hídricos disponíveis em algumas regiões.

Em geral, essas microbacias englobam diferentes cidades. Assim, mesmo que trabalhando com dados agregados, este tipo de estudo pode permitir a captação dos efeitos de importantes variáveis explicativas para o consumo de água. 


\section{BIBLIOGRAFIA}

ARCHIBALD, G.G. Forecasting water demand - a disaggregated approach. Journal of Forecasting, v.2, n.2, p. 181-192. 1983.

ANDRADE, T.A.; BRANDÃO, A.S.P.; WHITCOMB, J.B. et. al. Estudos da Função Demanda por Serviços de Saneamento e Estudos da Tarifação do Consumo Residencial. Brasília: IPEA, 1996. 61p. (Texto para discussão IPEA, n. 415)

BILLINGS, B.R. Specification of block rate variables in demand models. Land Economics v. 58,, n.3, p.386-394, Aug. 1982.

BILLINGS, B.R.; AGTHE, D.E. Price elasticities for water: a case of increasing block rates. Land Economics, v. 56, n.1, p.73-84, Feb. 1980.

BILLINGS, B.R.; AGTHE, D.E. Price elasticities for water: a case of increasing block rates: reply. Land Economics, v. 57, n.2, p.276-8, May 1981.

BOTKIN, D.B.; KELLER, E. Environmental science - earth as a living planet. New York: John Wiley \& Sons, 1995. 627p.

BOX, G.E.P.; JENKINS, G.M. Time series analyses: forecasting and control. San Francisco: Holden-day, 1976. 575p.

BOX, G.E.P.; JENKINS, G.M.; REINSEL, G. Time series analysis: forecasting and control. New Jersey: Prentice Hall/Englewood Cliffs, 1994. 598p. 
BOYAYAN,M. Como tratar a água suja. Globo Ciência, v. 8, n.85, p.55-61, ago. 1998.

CABRAL, B. Em busca da eficiência. Agroanalysis, v.18, n.3, p.46-49. mar. 1998.

CAMPOS, J.D. A lei posta em prática. Agroanalysis, v.18, n.3, p.22-23. Mar 1998.

CARRERA-FERNADEZ, J.; MENEZES, W.F. Avaliação contingente e a estimativa da função de demanda por água potável. Revista Econômica do Nordeste v. 31, n. 1, p. 9-34, jan/mar.2000

CHICOINE, D.L. ; RAMAMURTHY, G. Evidence on the specification of price in the study of domestic water demand. Land Economics v.62, n.1. p.26-32, Feb. 1986

CLARK, R.M.; STEVIE, R.G. A water supply cost model incorporating spatial variables. Land Economics, v. 57 n. 1. p.18-32. Feb. 1981.

COUTO, O.G. O uso da água no Brasil. Banas Ambiental, v. 1, n. 1, p.18-19, ago. 1999.

DAGUM, E.B. Revisions of time varying seasonal filters. Journal of Forecasting, n.1, p.173-187, 1982.

DAGUM, E.B.; LANIEL, N. Revisions of trend cycle estimators of moving average seasonal adjustment method. Journal of Business and Economic Statistics v. 5, n. 2, p.177-189, 1987.

DANIELSON, L.E. An analysis of residential demand for water using micro time-series data. Water Resources Research, v.15, n.4, p. 763-767, Aug.1979 
DEATON, A.; MUELLBAUER, J. Economics and consumer behavior. New York: Cambridge University Press, 1980. 450p.

DELLER, E.T.; CHICONE, D.L.; RAMAMMURTHY, G. Instrumental variables approach to rural water service demand. Southern Economic Journal, v.53, p.333-346, Oct. 1986.

DREW, D. Processos interativos homem-meio ambiente. São Paulo: DIFEL, 1986. 206p.

DICKEY, D.A.; FULLER, W.A. Likelihood ratio statistics for autoregressive time series with a unit root. Ecomometrica, v.49, n.4, p.1057-1072, July 1981.

EMBRAPA. Atlas do meio ambiente. In: GALVÃO, L.E. As águas não vão mais rolar, o alto preço do desperdício. Rumos, v. 24, n. 168, p.26-33, jan. 2000.

ESPEY, M.; ESPEY, J.; SHAW, W.D. Price elasticity of residential demand for water: a meta-analysis. Water Resources Research, v. 33, n.6, p.13691374, June 1997.

FOSTER, H.; BEATTIE, B.R. Urban residential demand for water in the United States: reply. Land Economics, v.57, n.2, p.257-65, May 1981.

FOSTER, H.; BEATTIE, B.R. Urban residential demand for water in the U.S. Land Economics, v.55, n. 1, p.43-58, Feb. 1979.

FRANÇA, D. O planeta água está secando, Globo Ciência, v. 8, n. 85, p.57, ago. 1998.

GALVÃO, L.E. As águas não vão mais rolar, o alto preço do desperdício. Rumos, v. 24, n. 168, p.26-33, jan.2000. 
GARRIDO, R. Os novos conceitos. Agroanalysis, v.18, n.3, p. 20-21. mar. 1998.

GIANSANTI, A.E. A água como um bem econômico. São Paulo, 1993. 431p. Tese (Doutorado) - Escola Politécnica, Universidade de São Paulo.

GOTTLIED, M. Urban domestic demand for water: a Kansas study. Land Economics, v. 39, p. 204-210, May 1963.

GRIFFIN, A.H.; MARTIN, W.E. Price elasticities for water: a case of increasing block rate: comment. Land Economics, v.57, n.2, p. 266-75, May 1981.

GRIFFIN, A.H.; MARTIN, W.E.; WADE, J.C. Urban residential demand for water in the United States: comment. Land Economics v.57, n.2, p.252256, May 1981.

GRIFFIN, R.C.; CHANG,C. Pretest analyses of water demand in thirty communities. Water Resources Research, v. 26, n.10, p.2251-2255. Oct. 1990.

HANSEN, L.G. Water and energy price impacts on residential water demand in Copenhagen. Land Economics v.72, n.1, p. 66-69, Feb.1996.

HAUSMAN, J.A. Specification tests in econometrics. Econometrica, v.46, p.1251-1271, Nov. 1978.

HENSON, S.E. Electricity demand estimates under increasing block rates. Southern Economic Journal, v.61, p.262-289, Aug. 1984.

HESPANHOL, I. Água e saneamento básico - uma visão realista. In: REBOUÇAS, A.C.; BRAGA, B.; TUNDISI, J.G. Água doce no Brasil. São Paulo: Escrituras Editora, 1999. cap. 7, p.249-303. 
HEWITT, J.A.; HANEMANN, W.M. A discrete/continuous choice approach to residential water demand under block rates pricing. Land Economics, v.71, n.2, p.173-192, May 1995.

HILCKAMA, T.E.A. Water Resources. in: Murdock, W.W. (ed.) Environment Resources, Pollution and Society. Sunderland: Sinauer Associates, 1975. 488p.

HOWE, C.W.; LINAWEVER Jr., F.P. The impact of price on residential water demand and its relation to system design and price structure. Water Resource Research, v.3, n.1, p.13-32, 1967.

JONES, C.V.; MORRIS, J.R. Instrumental price estimates and residential water demand. Water Resources Research, v.20, n.2, p.197-202, Feb. 1984.

KASSOULF, A.L. Previsão de preços na pecuária de corte no estado de São Paulo, Piracicaba, 1988. 102p. Dissertação (Mestrado) Escola Superior de Agricultura "Luiz de Queiroz", Universidade de São Paulo.

KRAUSE, G. O crime ambiental não compensa. Agroanalysis, v.18, n.3, p.1-4, mar. 98.

MACKINNON, J.G. Critical values for cointegration tests. In: ENGLE, R.F.; GRANGER,C.W.J.(Eds.) Long-run economics relationships: readings in cointegration. Oxford: Oxford University Press, 1991, p. 267-276.

MARGARIDO, M.A. Transmissão de preços intemacionais de suco de laranja para preços ao nível de produtor de laranja no estado de São Paulo. São Paulo, , 1994. 96p. Dissertação (Mestrado). Escola de Administração de Empresas de São Paulo, Fundação Getúlio Vargas. 
MARGARIDO, M.A.; ANEFALOS, L.C. Testes de raiz unitária e o software SAS. Agricultura em São Paulo, v.42, n.2, p.19-45, 1999.

MARGARIDO, M.A.; SOUZA, E.L.L. Formação de preços da soja no Brasil. Agricultura em São Paulo, v.45, n.2, p.56-61, 1998.

MARTIN, W.E.; THOMAS, J.F. Policy relevance in studies of urban residential water demand. Water Resources Research, v.22, n.13, p.1735-1741, dec. 1986.

MATTOS, Z.P.B. Uma análise da demanda residencial por água usando diferentes métodos de estimação. Pesquisa e Planejamento Econômico. v.28, n.1, p. 207-223, jan. 1998.

MCFADDEN, D.; PUIG, C.; KIRSHNER, D. Determinants of the long-run demand for electricity. In: American Statistical Association, Proceedings, Business and Economics Section, part 1, p.109-113. aug. 1977

MORGAN, W.D. Residential Water Demand: the case from micro data. Water Resources Research, v.9, n.4, p.1065-1067, aug. 1973.

NAZEN, S.M. Applied time series analysis for business and economic forecasting. New York: Ed. M.Dekker, 1998.

NEBEL, B.T.; WRIGHT, R.T. Environmental science: the way the world works. Englewood Chiffs:Prentice Hall. $6^{\underline{a}}$ ed. 1988. 698p.

NIESWIADOMY, M.L.; MOLINA, D.J. Comparing residential water demand estimates under decreasing and Lon creasing block rates using household data. Land Economics, v. 65, n. 3, p.280-304, aug. 1989.

NORDIN, J.A. A proposed modification of Taylor's demand analysis: comment The Bell Journal of Economics, v.7, p.719-721, autumn 1976. 
NOVAES, R. Água: o que falta é qualidade. Banas Ambiental, v. 1, n. 1, ago. 1999.

OPALUCH, J.J. Urban residential demand for water for water in the United States: further discussion. Land economics, v.58, p.225-227, May 1982.

PEREIRA Jr., J.S. Porque gerir os recursos hídricos. Agroanalysis, v.18, n.3, p.16-19. Mar.1998.

PINDYCK, R.S.; RUBINFELD, D.L. Microeconomia. 2 ed. São Paulo: Makron Books, 1994. 969p.

PINHEIRO, J.C.V. Valor econômico da água para irrigação no semi-árido cearense. Piracicaba, 1998. 161p. Dissertação (Mestrado). Escola Superior de Agricultura "Luiz de Queiroz", Universidade de São Paulo.

PINO, F.A. Análise de intervenção em séries temporais: aplicações em economia agrícola. São Paulo, 1980. Dissertação (Mestrado). Instituto de Matemática e Estatística, Universidade de São Paulo.

PINO, F.A.; FRANCISCO, V.L.F.S.; CÉSAR, S.A.G. et al. Sazonalidade em série temporais: um levantamento sobre o estado da arte. Agricultura em São Paulo, v. 41, n.3, p.103-133, 1994.

POLZIN, P.E. The specification of price in studies of consumer demand under block price scheduling: additional empirical evidence. Land economics, v.60, n.3, p.306-309, Aug. 1984.

RANDALL, A. Resource Economics. New York: John Wiley \& Sons, 1987. 434p.

RAO, B.B. Editor's introduction. In: RAO, B.B. Cointegration for the applied economist. New York: ST. Martin's Press, 1994. p.1-8. 
REBOUÇAS, A.C. Água doce no mundo e no Brasil. In: REBOUÇAS, A.C.; BRAGA, B.; TUNDISI, J.G. Água doce no Brasil. São Paulo: Escrituras Editora, 1999. cap.1, p.1-36

ROMANO, P.A. A cultura da abundância levou a acomodação. Agroanalysis, v.18, n.3, p.7-11, mar.1998.

RUFFIN, R.J.; GREGORY, P.R. Principles of microeconomics. Illinois: Scott, Foresman end Coompany. 1983. 464p.

RUTKOWSKI, E. Desenhando a bacia ambiental - Subsídios para o planejamento das águas doces metropolitan(izad)as. 1999. 160p Faculdade de Arquitetura e Urbanismo, Universidade de São Paulo. Tese (Doutorado)

SALATI, E,; LEMOS, H.M.; SALATI, E. Água e o desenvolvimento sustentável. In: REBOUÇAS, A.C.; BRAGA, B.; TUNDISI, J.G. Água doce no Brasil. São Paulo: Escrituras Editora, 1999. cap. 2, p.39-62.

SAS INSTITUTE. SASIETS user's guide, version 6. 2 ed. Cary, 1993. 1022p.

SHIN, J.S. Perception of price when information is costly: evidence from residential electricity demand. Review of Economics and Statistics v.67, p.591-598, Nov. 1985.

SILVA, J.R.; BRITO, R.J. Taxas de outorga e consumo de águas não tratadas: novos tributos que poderão onerar o setor produtivo. Produtor Rural. n.80, jul.1999.

SPIRN, A.W. O jardim de granito: a natureza no desenho da cidade. São Paulo. EDUSP. 1995. 345p

TAYLOR, L.D. The demand for electricity: a survey. The Bell Journal of Economics, v.6, p.74-110, Spring 1975. 
TEIXEIRA, J.L. Futuro ameaçado: vem aí a cobrança pelo uso da água. Será o fim do desperdício? Problemas Brasileiros, n. 338, mar/abr 2000.

TERZA, J.V.; WELLCH, W.P. Estimating demand under block rates: electricity and water. Land Economics, v.58, p.181-188, May 1982.

U.S.DEPARTMENT OF COMMERCE. Bureau of Economics Analysis. The X11 variant of the Census Method II seasonal adjustment program. U.S. Washington : Govemment Printing Office, 1996.

VANDAELE, W. Applied time series and Box-Jenkins models. New York. Academic Press, 1983. 417p.

WONG, S.T. A model of municipal water demand: a case study of Northeastern Illinois. Land Economics. v.48, n.2, p.181-188, Feb. 1972.

YOUNG, R.A. Price elasticity of demand for municipal water: a case study of Tucson, Arizona. Water Resources Research, v.9, n.4, p.1068-1073, Aug. 1973.

ZARNIKAU, J. Spot market pricing of water resources and efficient means of rationing water during scarcity (water pricing). Resource and Energy Economics, v.16, p.189-210. 1994

ZIONI, C. Todos usam. Quem cuida? Problemas Brasileiros n.338, p.40, mar.abr. 2000. 